US Army Corps

of Engineers 。

Prepared for the U.S. Army Corps of Engineers, Portland District,

under an Interagency Agreement with the U.S. Department of Energy

Contract DE-AC05-76RL01830

\title{
Hydroacoustic Evaluation of Juvenile Salmonid Passage and Distribution at Lookout Point Dam, 2010
}

\section{FINAL REPORT}
F Khan
ES Fischer
GE Johnson
DM Trott
IM Royer
GR Ploskey
JS Hughes

May 2012

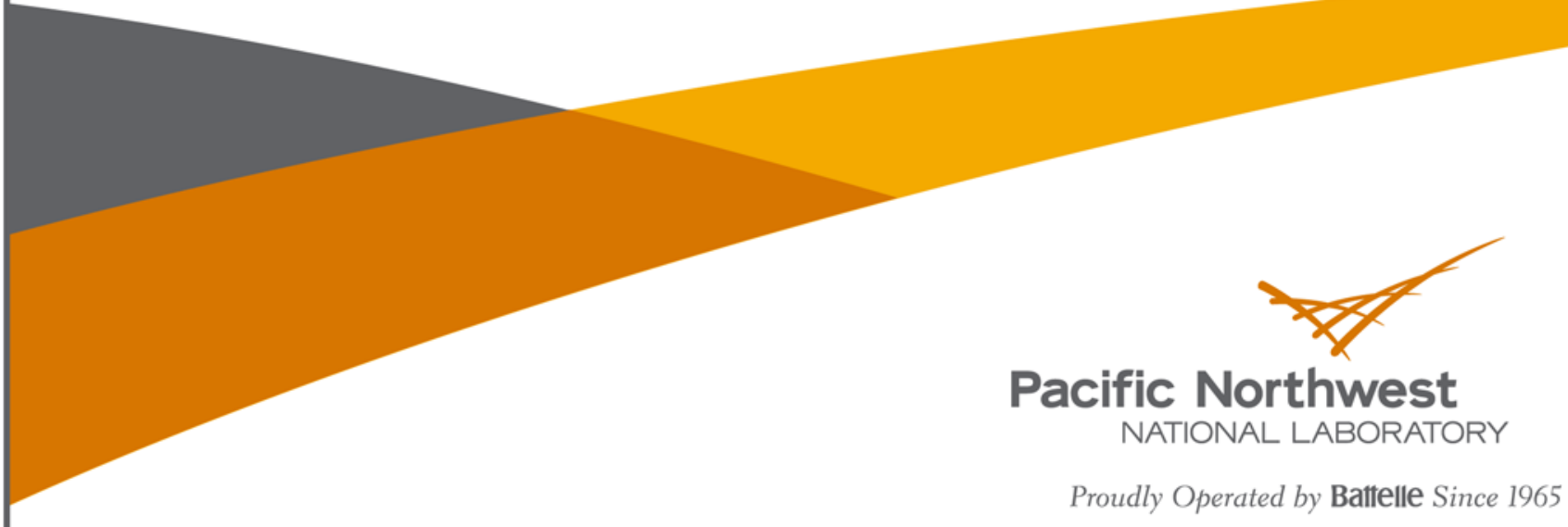




\title{
DISCLAIMER
}

This report was prepared as an account of work sponsored by an agency of the United States Government. Neither the United States Government nor any agency thereof, nor Battelle Memorial Institute, nor any of their employees, makes any warranty, express or implied, or assumes any legal liability or responsibility for the accuracy, completeness, or usefulness of any information, apparatus, product, or process disclosed, or represents that its use would not infringe privately owned rights. Reference herein to any specific commercial product, process, or service by trade name, trademark, manufacturer, or otherwise does not necessarily constitute or imply its endorsement, recommendation, or favoring by the United States Government or any agency thereof, or Battelle Memorial Institute. The views and opinions of authors expressed herein do not necessarily state or reflect those of the United States Government or any agency thereof.

\author{
PACIFIC NORTHWEST NATIONAL LABORATORY \\ operated by \\ BATTELLE \\ for the \\ UNITED STATES DEPARTMENT OF ENERGY \\ under Contract DE-AC05-76RL01830
}

Printed in the United States of America

Available to DOE and DOE contractors from the Office of Scientific and Technical Information,

P.O. Box 62, Oak Ridge, TN 37831-0062;

ph: (865) 576-8401

fax: $(865) 576-5728$

email: reports@adonis.osti.gov

Available to the public from the National Technical Information Service,

U.S. Department of Commerce, 5285 Port Royal Rd., Springfield, VA 22161

ph: (800) 553-6847

fax: (703) 605-6900

email: orders@ntis.fedworld.gov

online ordering: http://www.ntis.gov/ordering.htm

This document was printed on recycled paper.

$(9 / 2003)$ 


\section{Hydroacoustic Evaluation of Juvenile Salmonid Passage and Distribution at Lookout Point Dam, 2010}

FINAL REPORT

F Khan

ES Fischer

GE Johnson

DM Trott

IM Royer

JS Hughes

GR Ploskey

May 2012

Prepared for

U.S. Army Corps of Engineers, Portland District

Under an Interagency Agreement with

the U.S. Department of Energy

Contract DE-AC05-76RL01830

Pacific Northwest National Laboratory

Richland, Washington 99352 



\begin{abstract}
Pacific Northwest National Laboratory evaluated juvenile salmonid passage and distribution at Lookout Point Dam (LOP) on the Middle Fork Willamette River for the U.S. Army Corps of Engineers, Portland District (USACE), to provide data to support decisions on long-term measures to enhance downstream passage at LOP and others dams in USACE's Willamette Valley Project. This study was conducted in response to the listing of Upper Willamette River Spring Chinook salmon (Oncorhynchus tshawytscha) and Upper Willamette River steelhead (O. mykiss) as threatened under the Endangered Species Act. The results of the hydroacoustic study of juvenile salmonid passage and distribution at LOP provide new and, in some cases, first-ever data on passage estimates, run timing, distributions, and relationships between fish passage and environmental variables at the dam. The high-resolution spatial and temporal data reported provide detailed information about vertical, horizontal, diel, daily, and seasonal fish passage rates, and distributions at LOP from March 2010 through January 2011. This information will inform management decisions on the design and development of surface passage and collection devices to help restore Chinook salmon populations in the Middle Fork Willamette River watershed above Lookout Point Dam.
\end{abstract}





\section{Summary}

This report presents the results of an evaluation of juvenile salmonid passage and distribution at Lookout Point Dam (LOP) on the Middle Fork Willamette River. The study was conducted by the Pacific Northwest National Laboratory for the U.S. Army Corps of Engineers, Portland District (USACE). The goal of the study was to provide fish passage and distribution data to support decisions on long-term measures to enhance downstream passage at LOP and others dams in USACE's Willamette Valley Project in response to the listing of Upper Willamette River Spring Chinook salmon (Oncorhynchus tshawytscha) and Upper Willamette River steelhead (O. mykiss) as threatened under the Endangered Species Act.

During the year-long study period—February ${ }^{1}$ 1, 2010 to January 31, 2011 ${ }^{2}$ — the objectives of the hydroacoustic evaluation of fish passage and distribution at LOP were as follows:

1. Estimate passage rates, run timing, horizontal distribution, and diel distribution at turbine penstock intakes for smolt-size fish. $^{3}$

2. Analyze the relationships between daily fish passage and Julian day, total project discharge, forebay elevation, forebay elevation delta, and water temperature.

3. Estimate passage rates, run timing, and diel distribution at turbine penstock intakes for small-size fish. $^{2}$

4. Estimate passage rates, passage efficiency, and run timing at the regulating outlets (ROs) for smoltsize fish.

5. Estimate vertical distribution of smolt-size and small-size fish in the forebay near the upstream face of the dam.

The fixed-location hydroacoustic technique was used to accomplish the objectives of this study. Transducers (420 kHz) were deployed in each penstock intake, above each RO entrance, and on the dam face; a total of nine transducers (two single beams and seven split beams) were used. To overcome the lack of species discrimination in the hydroacoustic data, we attempted to use species composition data from USACE's tailrace screw traps to apportion the hydroacoustic estimates among species of fish captured in the traps, but the sampling regimes for each method were quite different, precluding species apportionment of the hydroacoustic data. Therefore, the hydroacoustic estimates include passage of some portion of non-salmonids. The total catch in the tailrace screw traps was $89 \%$ Chinook salmon during 2010.

Forebay surface elevation during the study generally followed the prescribed rule curve. Water surface elevation relative to mean sea level (msl) began to increase in early February, peaked on June 3 (El. $898 \mathrm{ft}$ ), decreased through July, held at approximately El. $849 \mathrm{ft}$ above msl through August, and decreased for the fall drawdown from September 1 through October. From late October to the end of the study on January 31, forebay elevation was relatively low and fluctuated due to runoff from winter storm events.

\footnotetext{
${ }^{1}$ Field work to deploy equipment started in February, followed by data collection commencing in March.

${ }^{2}$ Deployment and transducer optimization began on February 1, 2010. Data collection commenced on March 10, 2010 and ended on January 31, 2011.

${ }^{3}$ For the purpose of analysis in this study, smolt-size fish were defined as $90 \mathrm{~mm}<$ fork length $<300 \mathrm{~mm}$ and small-size fish were defined as $65 \mathrm{~mm}<$ fork length $<90 \mathrm{~mm}$. The lengths are approximations based on acoustic target strength.
} 
Average daily project discharge remained fairly constant ( 1.25 kcfs) from February through the end of April, increased in May and peaked on June 2 (8.83 kcfs), decreased through the summer, and increased again in the winter with a second peak on January 23 (8.70 kcfs). The ROs were operated for 13 days in early summer and 49 days in winter. The spillway was not opened during the study. Dam operations usually involved power-peaking in morning and evening hours.

The study results provide new and, in some cases, first-ever data about passage estimates, run timing, and horizontal, diel, and vertical distributions and relationships between fish passage and environmental variables at the dam. Findings from this 1 year of study should be applied carefully because annual variation can be expected due to variability in adult salmon escapement, egg-to-fry and fry-to-smolt survival rates, reservoir rearing and predation, dam operations, and weather, etc. We summarize the findings from the hydroacoustic evaluation of juvenile salmonid passage and distribution at LOP during February 2010 through January 2011 as follows:

- Fish passage rates for smolt-size fish ( $>\sim 90 \mathrm{~mm}$ and $<300 \mathrm{~mm}$ ) were highest during DecemberJanuary and lowest in mid-summer through early fall. Passage peaks were also evident in early spring, early summer, and late fall.

- During the entire study period, an estimated total of 142,463 fish $\pm 4,444$ (95\% confidence interval) smolt-size fish passed through turbine penstock intakes. Of this total, 84\% passed during DecemberJanuary.

- Diel periodicity of smolt-size fish showing crepuscular peaks was evident in fish passage into turbine penstock intakes.

- Run timing for small-size fish ( 65-90 mm) peaked (702 fish) on December 18. Downstream passage of small-size juvenile fish was variable (see the confidence interval for the total passage estimate below), occurring on 2 days in the spring (March 11 and April 4), 8 days in the summer, and at times throughout late fall and winter. A total of 7,017 \pm 690 small-size fish passed through the turbine penstock intakes during the study period.

- In linear regression analyses, daily fish passage (turbines and ROs combined) for smolt-size fish was significantly related to project discharge $(P<0.001)$. This relationship was positive, but there was no relationship between total project passage and forebay elevation $(P=0.48)$ or forebay elevation delta, i.e., day-to-day change in forebay elevation $(P=0.16)$.

- In multiple regression analyses, a relatively parsimonious model was selected that predicted the observed data well. The multiple regression model indicates a positive trend between expected daily fish passage and each of the three variables in the model—Julian day, log(discharge), and $\log (\operatorname{abs}($ forebay delta)); i.e., as any of the environmental variables increase, expected daily fish passage increases.

- Relatively few fish passed into the ROs when they were open in summer (2 fish/d) and winter (8 fish/d). Overall, when the ROs were open, RO efficiency (RO passage divided by total project passage) was 0.004 .

- Fish were surface-oriented with $62 \%-80 \%$ occurring above $10 \mathrm{~m}$ deep. The highest percentage of fish (30\%-60\%) was in the 5-10-m-depth bin. 
- During spring and summer, mean target strengths for the analysis periods ranged from -44.2 to -42.1 $\mathrm{dB}$. These values are indicative of yearling-sized juvenile salmon. In contrast, mean target strengths in fall and winter were about $-49.0 \mathrm{~dB}$, which are representative of subyearling-sized fish.

We draw the following conclusions from the study:

- The non-obtrusive hydroacoustic data from this study are reliable because passage estimates and patterns were similar to those observed in the direct-capture data from the tailrace screw trap and were consistent with distribution patterns observed in other studies of juvenile salmonid passage at dams.

- Hydroacoustically estimated run timing coupled with fish size data from screw traps indicate four life-history strategies may have been expressed by Chinook salmon passing LOP during 2010: early spring yearlings, early summer yearlings, late fall/winter yearlings, and late fall/winter subyearlings.

- Operational and biological factors influencing fish passage, however, are confounded in an observational field study such as ours, making it difficult to discern between juvenile salmon movement and migration downstream. Factors influencing fish passage are a complex, varying combination of operational and biological variables.

- The surface-oriented vertical distribution of fish we observed supports development of surface passage or collector devices.

- Collector design should support multiple life histories of fish emigrating at various times of the year.

We offer the following recommendations for future research at LOP to support the design of fish passage or collection systems:

- Consider a quick, focused test of surface spill to demonstrate whether juvenile salmonids will pass at a time of year when emigrants are expected.

- Consider mobile hydroacoustic surveys coupled with direct observations to provide estimates of juvenile salmonid distribution and abundance by fish size class in the LOP reservoir.

- Consider applying acoustic imaging techniques to quantify fish behavior, distributions, and movements and index abundance at key locations, such as using head-of-reservoir or in-reservoir sampling devices or prototype surface collectors.

In closing, the high-resolution spatial and temporal data reported herein provide detailed information about vertical, horizontal, diel, daily, and seasonal fish passage rates and distributions at LOP from March 2010 through January 2011. This information will support management decisions on design and development of surface passage and collection devices to help restore Chinook salmon populations in the Middle Fork Willamette River watershed above LOP. 



\section{Preface}

This study was conducted by the Pacific Northwest National Laboratory (PNNL) for the U.S. Army Corps of Engineers, Portland District (USACE), to support research and management decisions to restore anadromous fish runs in the Willamette basin. The USACE technical lead was David Griffith (503 808 4773) and the PNNL project manager was Fenton Khan (509 371 7230). The data are archived at PNNL offices in Richland, Washington. This final report is a project deliverable (PNNL Project No. 58030) and incorporates fisheries agencies' review comments on the draft report. PNNL is operated by the Battelle Memorial Institute for the U.S. Department of Energy under Contract DE-AC05-76RL01830.

A suggested citation for the report is: Khan F, GE Johnson, IM Royer, JS Hughes, ES Fischer, DM Trott, and GR Ploskey. 2012. Hydroacoustic Evaluation of Juvenile Salmonid Passage and Distribution at Lookout Point Dam, 2010. PNNL-20362, final report submitted to the U.S. Army Corps of Engineers, Portland District, Portland, Oregon, by Pacific Northwest National Laboratory, Richland, Washington. 



\section{Acknowledgments}

We thank the following people for their essential contributions to this study:

- U.S. Army Corps of Engineers, Portland District: David Griffith, Mike Langeslay, Kathryn Tackley, and Engineering and Reservoir Control staff.

- U.S. Army Corps of Engineers, Willamette Valley Project office: Doug Garletts, Chad Helms, Greg Taylor, and other biologists and staff from Operations, Electrical, and Structural and Maintenance crews. In addition to project support, the biologists also provided screw-trap data from the tailrace of Lookout Point Dam.

- Pacific States Marine Fisheries Commission: Aaron Cushing, Darin Etherington, Mike Kauffman, Tyler Mitchell, Tyrell Monter, and Matt Wilberding.

- PNNL: George Batten, Terrie Bear, Scott Carpenter, Gayle Dirkes, Susan Ennor, Kenneth Ham, Matt Hennen, Julie Hughes, Jina Kim, Kathy Lavender, Megan Peters, and Nathan Phillips.

- Precision Acoustic Systems: Alan Wirtz.

- Schlosser Machine Shop: Vincent Schlosser. 



\section{Acronyms and Abbreviations}

\begin{tabular}{|c|c|}
\hline AIC & Akaike's information criterion \\
\hline $\mathrm{BiOp}$ & Biological Opinion \\
\hline cfs & cubic feet per second \\
\hline CI & confidence interval \\
\hline d & day(s) \\
\hline $\mathrm{dB}$ & decibel(s) \\
\hline $\operatorname{deg}$ & degree(s) \\
\hline El. & elevation \\
\hline ESA & Endangered Species Act \\
\hline FCRPS & Federal Columbia River Power System \\
\hline $\mathrm{ft}$ & foot(feet) \\
\hline h & hour(s) \\
\hline kcfs & thousand cubic feet per second \\
\hline $\mathrm{kHz}$ & kilohertz \\
\hline LOP & Lookout Point Dam \\
\hline $\mathrm{m}$ & meter(s) \\
\hline $\mathrm{mm}$ & millimeter(s) \\
\hline $\min$ & minute(s) \\
\hline msl & mean sea level \\
\hline MW & megawatt(s) \\
\hline NMFS & National Marine Fisheries Service \\
\hline ODFW & Oregon Department of Fish and Wildlife \\
\hline PAS & Precision Acoustic Systems \\
\hline PNNL & Pacific Northwest National Laboratory \\
\hline pps & ping(s) per second \\
\hline RO & regulating outlet \\
\hline s & second(s) \\
\hline TS & target strength \\
\hline$\mu \mathrm{Pa}$ & micro-Pascal(s) \\
\hline USACE & U.S. Army Corps of Engineers, Portland District \\
\hline $\mathrm{V}$ & $\operatorname{volt}(\mathrm{s})$ \\
\hline WVP & Willamette Valley Project \\
\hline
\end{tabular}





\section{Contents}

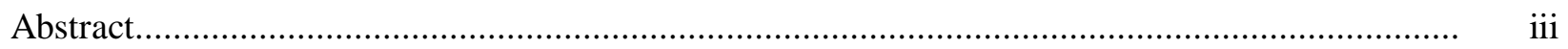

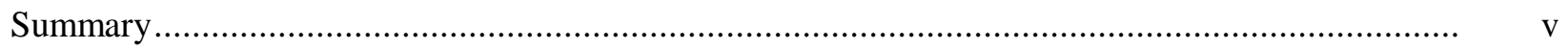

Preface

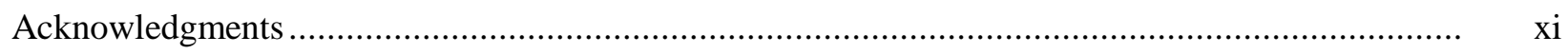

Acronyms and Abbreviations...................................................................................................... xiii

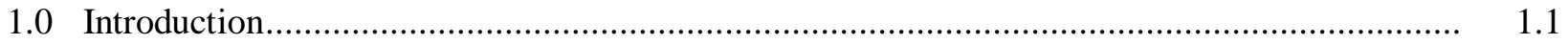

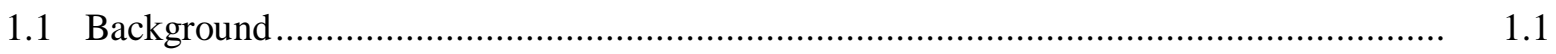

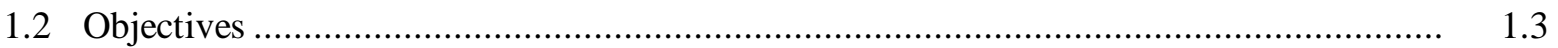

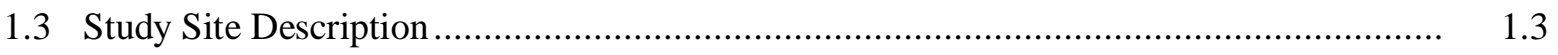

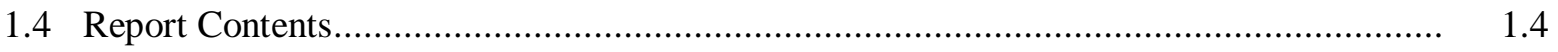

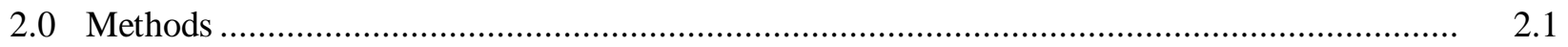

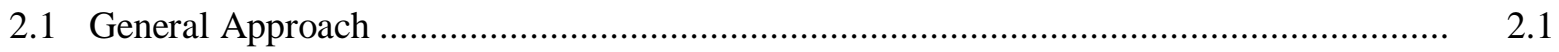

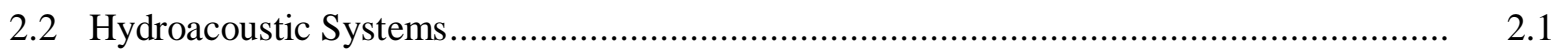

2.2.1 Transducer Locations and Orientations........................................................... 2.2

2.2.2 Turbine Penstock Intakes ........................................................................... 2.2

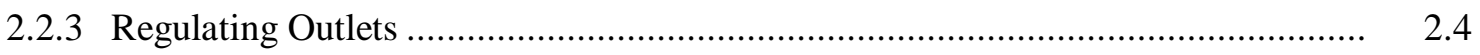

2.2.4 Forebay Dam Face ................................................................................... 2.5

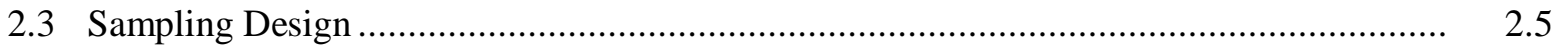

2.4 Data Processing and Passage Estimation................................................................... 2.5

2.5 Regression Models and Akaike’s Information Criterion ............................................ 2.7

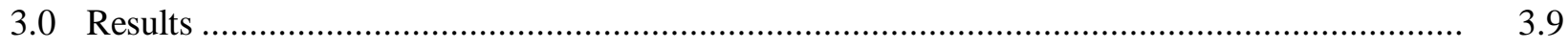

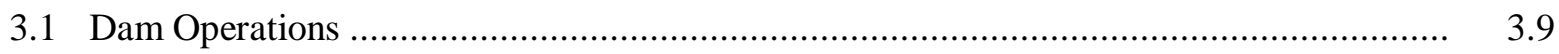

3.1.1 Forebay Elevation ..................................................................................... 3.9

3.1.2 Turbine and RO Discharge ............................................................................. 3.10

3.2 Fish Passage and Distribution .......................................................................... 3.12

3.2.1 Turbine Penstock Intakes - Smolt-Size Fish .................................................. 3.13

3.2.2 Turbine Penstock Intakes - Small-Size Fish .................................................... 3.16

3.2.3 Relationships between Fish Passage and Environmental Variables ....................... 3.18

3.2.4 Regulating Outlets - Smolt-Size Fish ......................................................... 3.27

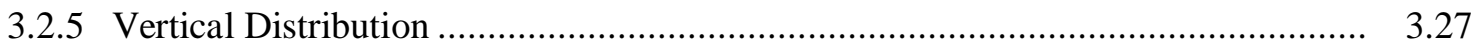

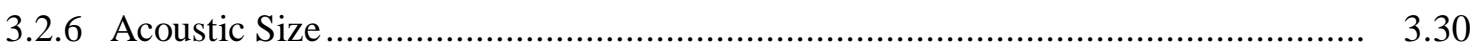

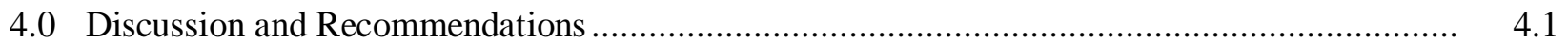

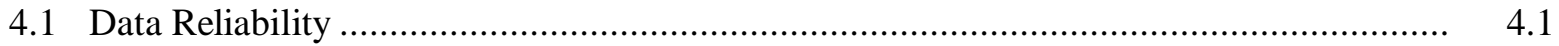

4.2 Passage and Environmental Factors .......................................................................

4.3 Implications for Collector Design .....................................................................

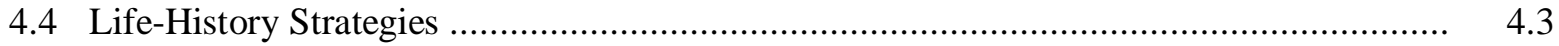

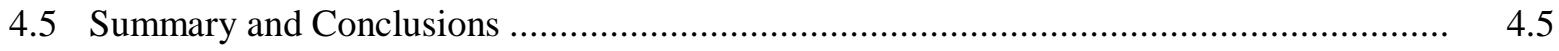




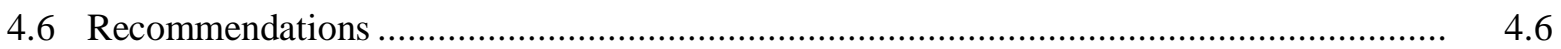

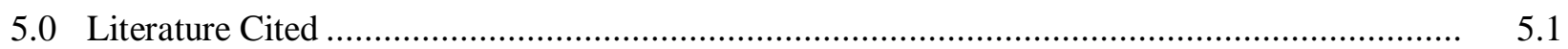

Appendix A - Hydroacoustic System Parameters …................................................................... A.1 


\section{Figures}

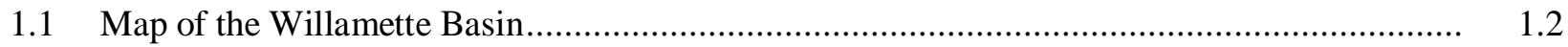

1.2 Aerial Photograph of Lookout Point Dam........................................................................

1.3 Upstream Face of LOP Showing Locations of the Penstocks, ROs, and Spill Bays ................ 1.4

2.1 Front View of Lookout Point Dam Showing Approximate Transducer Locations .................. 2.2

2.2 Cross-Sectional View of a Transducer Deployment at a Penstock Intake ............................. 2.3

2.3 Cross-Sectional View of a Calculated Transducer Deployment Angle at a Penstock Intake ... 2.3

2.4 Cross-Sectional View of a Transducer Deployment with Calculated Angle at the RO ............ 2.4

2.5 Front View Depicting the Orientation of a Transducer at an RO ........................................ 2.4

3.1 Daily Average Surface Elevation of the Forebay at LOP from February 2010 through January 2011 During Each of the Seven Periods Listed Above

3.2 Average Daily Discharge for the Turbines and Regulating Outlets at LOP from February 2010 Through January 2011 During Each of the Seven Periods Listed Above. ...................... 3.11

3.3 Turbine Operations from February 2010 through January 2011 ...................................... 3.12

3.4 Estimated Daily Passage of Smolt-Size Fish at LOP Turbine Penstock Intakes from March 10, 2010 through January 31, 2011....................................................................... 3.14

3.5 Estimated Daily Passage of Smolt-Size Fish at LOP Turbine Penstock Intakes from March 10 through November 30, 2010.

3.6 Horizontal Distribution of Smolt-Size Fish Passage at the Turbine Penstock Intakes When All Three Units Were Operating and Fish Passed All Units

3.7 Diel Distribution of Smolt-Size Fish Separately for the Seven Dam Operations Periods.......... 3.16

3.8 Estimated Daily Passage of Small-Size Fish at LOP Turbine Penstock Intakes from March 10, 2010, through January 31, $2011 .$.

3.9 Diel Distribution of Small-Size Fish Separately for Five of the Seven Dam Operations Periods.

3.10 Matrix of Bivariate Scatterplots

3.11 Daily Distribution During March 10, 2010 to January 31, 2011 for Total Project Discharge, Forebay Elevation, Forebay Elevation Delta, and Total Project Passage for Smolt-Size Fish...

3.12 Relationship between Passage for Smolt-Size Fish and Total Project Discharge

3.13 Relationship between Passage for Smolt-Size Fish and Forebay Elevation...

3.14 Relationship between Passage for Smolt-Size Fish and Forebay Elevation Delta ......

3.15 Scatterplot of Observed Versus Predicted Values for the Selected Model 3.26

3.16 Normal Probability Plot of Raw Residuals for the Selected Model. 3.26

3.17 Estimated Daily Passage of Smolt-Size Fish at LOP Regulating Outlets from December 5, 2010, through January 31, 2011...

3.18 Vertical Distribution of Fish at the Forebay Dam Face Expressed as the Proportion of Fish in the Surface $10 \mathrm{~m}$ by Dam Operations Period .

3.19 Vertical Distribution of Small-Size and Smolt-Size Fish and Water Temperature at the Forebay Dam Face Separately by Dam Operations Period.

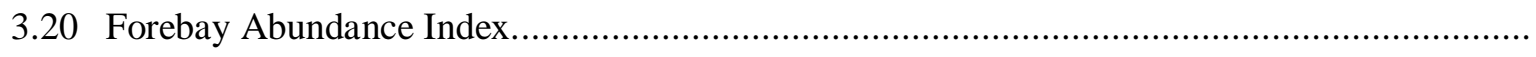

4.1 Run Timing for Smolt-Size Fish Depicting Possible Life-History Strategies at LOP During March 2010 Through January 2011. 


\section{Table}

2.1 Sample Locations and Spatial Sampling Intensity at Lookout Point Dam in 2010 .................. 2.1

3.1 Correlation Table for Variables from LOP Hydroacoustic Study 2010 ................................. 3.19

3.2 Variables Used in the Multiple Regression Models to Predict the Expected Value of Daily Fish Passage .....

3.3 Multiple Regression Models and AIC Scores .................................................................... 3.24

3.4 Estimated Coefficients for the Selected Model from Set 2, Step 6 ....................................... 3.25

3.5 Results of the Likelihood Type 3 Test for the Selected Model. ............................................. 3.25

3.6 Statistics for Goodness of Fit for the Selected Model ......................................................... 3.25

3.7 Target Strengths by Analysis Period ........................................................................... 3.30 


\subsection{Introduction}

This report presents the results of an evaluation of juvenile salmonid passage and distribution at Lookout Point Dam on the Willamette River in Oregon from February 2010 through January 2011. The study was conducted by the Pacific Northwest National Laboratory (PNNL) for the U.S. Army Corps of Engineers, Portland District (USACE). The goal of the study was to provide fish passage and distribution data to support decision-making related to long-term measures to enhance downstream passage at LOP and other dams in USACE's Willamette Valley Project.

\subsection{Background}

Salmon and steelhead populations in the Willamette River basin have been adversely affected by development and operation of hydroelectric dams in the basin. The collective set of dams, called the Willamette Valley Project (WVP), is owned and operated by the USACE. Federal dams have blocked access to historical spawning habitat, altered river discharge patterns, affected water temperature and sediment supply, and caused mortality to migrating anadromous fish (Keefer and Caudill 2010). In 1999, Upper Willamette River Spring Chinook salmon (Oncorhynchus tshawytscha) and Upper Willamette River steelhead (O. mykiss) were listed as threatened under the Endangered Species Act (ESA). Subsequently, the National Marine Fisheries Service (NMFS) issued a Biological Opinion (BiOp), called Willamette Project BiOp, on operation of the WVP in the Willamette basin (NMFS 2008).

The BiOp requires the USACE to improve operations and structures to reduce impacts on Upper Willamette River Spring Chinook salmon and steelhead caused by the WVP (NMFS 2008). As a part of these requirements, the USACE must develop interim operations and investigate the feasibility of surface collection structures and mechanisms to convey downstream migrating fish safely past the dam. In a draft plan for WVP research, monitoring, and evaluation, the USACE posed the following management questions (USACE 2009):

- What are the continuing effects of the Willamette Valley Project on Willamette ecosystem function and on ESA-listed fish species?

- What can effectively be done to protect, improve, restore, or mitigate for affected species, their habitat, and related ecosystem function while also maintaining authorized Willamette Project functions?

Therefore, an understanding of when, where, and how many juvenile salmonids pass through the dams, the relative efficiency of existing routes at passing them, temporal and spatial distributions, and their behavior in the near-dam forebay areas will be important for fisheries managers and the USACE to have in designing operations and structures that collect and/or pass juvenile salmonids safely and efficiently (USACE 2009; AECOM and BioAnalysts 2010; Keefer et al. 2011). One of the USACE's priority projects for research on juvenile salmonid migration characteristics during 2010 was Lookout Point Dam on the Middle Fork Willamette River (Figure 1.1).

Fish passage facilities, upstream or downstream, were not included in original design and construction of Lookout Point Dam (LOP), a high-head storage dam that became operational in 1954. Construction of LOP and Dexter Dam, the regulating project just downstream, resulted in an $80 \%$ loss of salmon habitat in the Middle Fork watershed, which historically supported a significant production of 
spring Chinook salmon (Keefer and Caudill 2010). After construction, a floating device to collect outmigrating juvenile salmon was tested in 1957 and 1958, but very few fish were captured, so the device was deemed to be useless (AECOM and BioAnalysts 2010). In 1993, the Oregon Department of Fish and Wildlife (ODFW) began collecting spring Chinook salmon adults at Dexter Dam below LOP and outplanting them in the Middle Fork Willamette River drainage above LOP to augment natural salmon production and increase the levels of marine-derived nutrients. For example, the ODFW outplanted about 4,000 fish per year above LOP from 2002 through 2007 (Keefer and Caudill 2010). Outplanting continues to this day, ultimately providing a source of juvenile salmon migrating through LOP. Steelhead are not outplanted above LOP because historically the watershed likely did not support winter steelhead populations (Keefer and Caudill 2010).

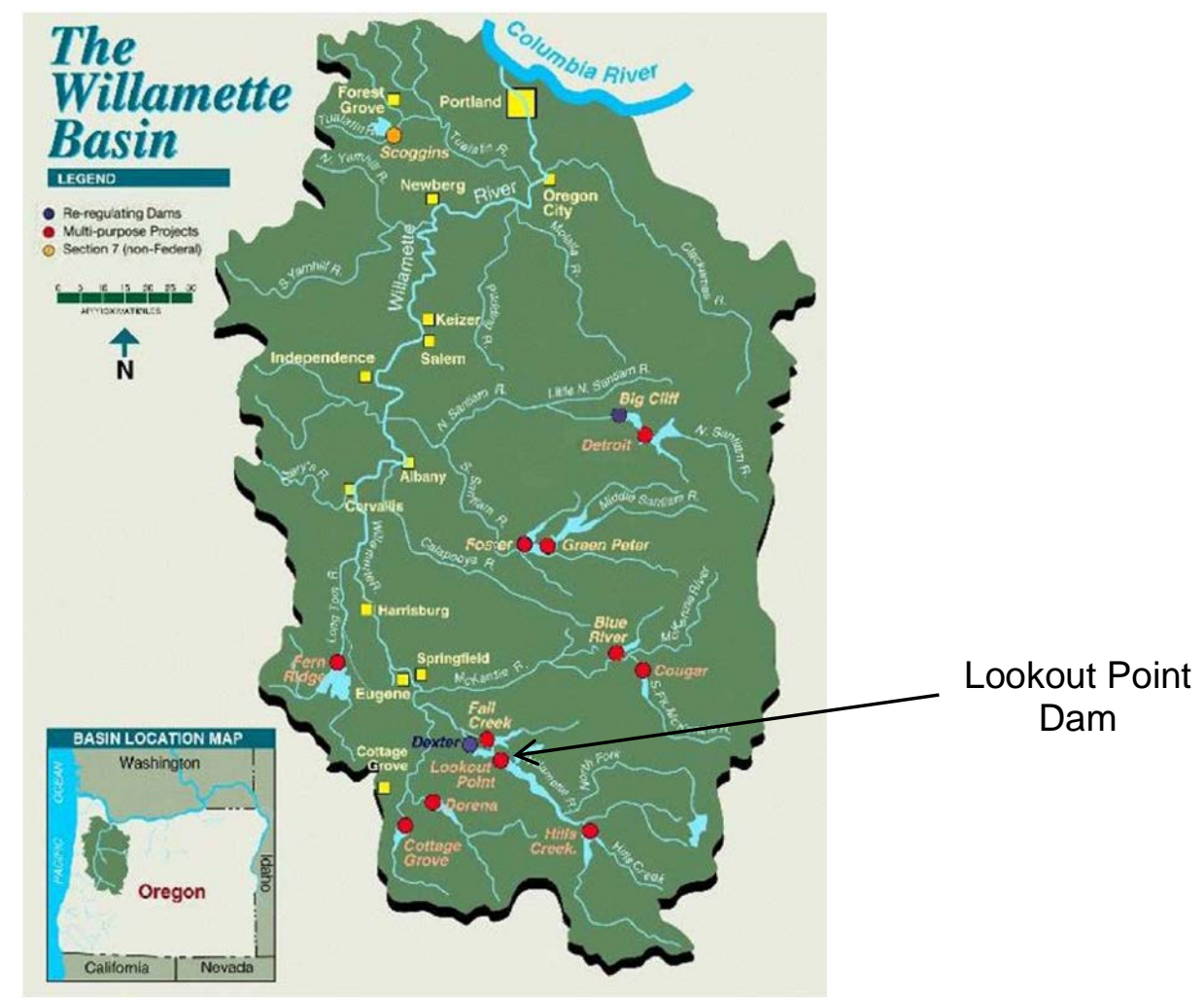

Figure 1.1. Map of the Willamette Basin (from Figure 2.1, NMFS 2008)

Keefer and Caudill (2010) provide an informative review of literature on adult salmon and steelhead life histories in the Willamette basin, including the Middle Fork. Keefer et al. (2011) synthesize data on juvenile fish migration characteristics at LOP from fish collections at screw traps operated by USACE personnel above and below dams in the Middle Fork Willamette River. They report multiple patterns for early life history, rough estimates of population size in the thousands or tens of thousands of juvenile Chinook salmon passing LOP, and highest passage during November-January, among other findings (Keefer et al. 2011). AECOM and BioAnalysis (2010) review surface collection literature and make recommendations for baseline research and design of such structures in-reservoir or in-stream above LOP. Both Keefer et al. (2011) and AECOM and BioAnalysts (2010) identify the need for improved understanding of passage and distribution at LOP. 
An appropriate technique for investigating fish passage and distribution at hydropower projects is fixed-location hydroacoustics (Thorne and Johnson 1993). Fixed-location hydroacoustics provides useful estimates of fish passage rates into portals at dams because it can have high sampling spatial and temporal intensity and is non-obtrusive. However, species identification using hydroacoustics is not possible, which is why direct-capture data are used to complement hydroacoustic data when species composition is uncertain (Ploskey and Carlson 1999). At LOP, juvenile salmonid and non-salmonid fishes definitely pass the dam as is evident from screw-trap data (Keefer et al. 2011). In general, hydroacoustics-based fish passage research conducted at Columbia River basin dams has informed USACE and fisheries managers. Research topics over the last 25 years have included spill efficiency, horizontal and vertical distributions, seasonal and diel distributions, surface flow outlet efficiency, and dam operations effects (e.g., Johnson et al. 1992, 2005; Khan et al. 2009, 2010; Ploskey and Weiland 2006; Ploskey et al. 2007b). Use of hydroacoustic techniques is appropriate to advance understanding of juvenile salmonid passage and distribution at LOP.

\subsection{Objectives}

During the year-long study period — from February 1, 2010 through January 31, 2011 — the objectives of the hydroacoustic evaluation of fish passage and distribution at LOP were as follows:

1. Estimate passage rates, run timing, horizontal distribution, and diel distribution at turbine penstock intakes for smolt-size fish. ${ }^{2}$

2. Analyze the relationships between daily fish passage and Julian day, total project discharge, forebay elevation, forebay elevation delta, and water temperature.

3. Estimate passage rates, run timing, and diel distribution at turbine penstock intakes for small-size fish. $^{3}$

4. Estimate passage rates, passage efficiency, and run timing at the regulating outlets for smolt-size fish.

5. Estimate vertical distribution of smolt-size and small-size fish in the forebay near the upstream face of the dam.

\subsection{Study Site Description}

Lookout Point Dam (Figure 1.1, Figure 1.2, and Figure 1.3) is located on the middle fork of the Willamette River, near Lowell, Oregon. The Congressionally authorized purposes of LOP are flood control, power generation, and irrigation. The dam has a powerhouse with three Francis turbine units, a maximum of $250 \mathrm{ft}$ of head, a total generating capacity of $120 \mathrm{MW}$, and a total hydraulic capacity of $9,300 \mathrm{cfs}$. The turbine penstock intake centerline is at El. $780 \mathrm{ft}$ at the trash racks. Maximum pool elevation is rated at $934 \mathrm{ft}$ above mean sea level (msl) and minimum flood control pool elevation ${ }^{3}$ is $825 \mathrm{ft}$ above msl (http://www.nwd-wc.usace.army.mil/report/lop.htm). The dam has four ROs and five spill bays as other means of passing water through the dam besides through the turbines. The RO

\footnotetext{
${ }^{1}$ Deployment and transducer optimization began on February 1, 2010. Data collection commenced on March 10, 2010 and ended on January 31, 2011.

${ }^{2}$ For the purpose of analysis in this study, smolt-size fish were defined as $90 \mathrm{~mm}<$ fork length $<300 \mathrm{~mm}$ and small-size fish were defined as $65 \mathrm{~mm}<$ fork length $<90 \mathrm{~mm}$. The lengths are approximations based on acoustic target strength (Love 1977).

${ }^{3}$ All elevations in this report are relative to mean sea level.
} 
centerline is at El. $730 \mathrm{ft}$ above msl. Operation of the ROs and spill bays depends on forebay pool elevation, turbine operations, runoff conditions, season, and other factors.

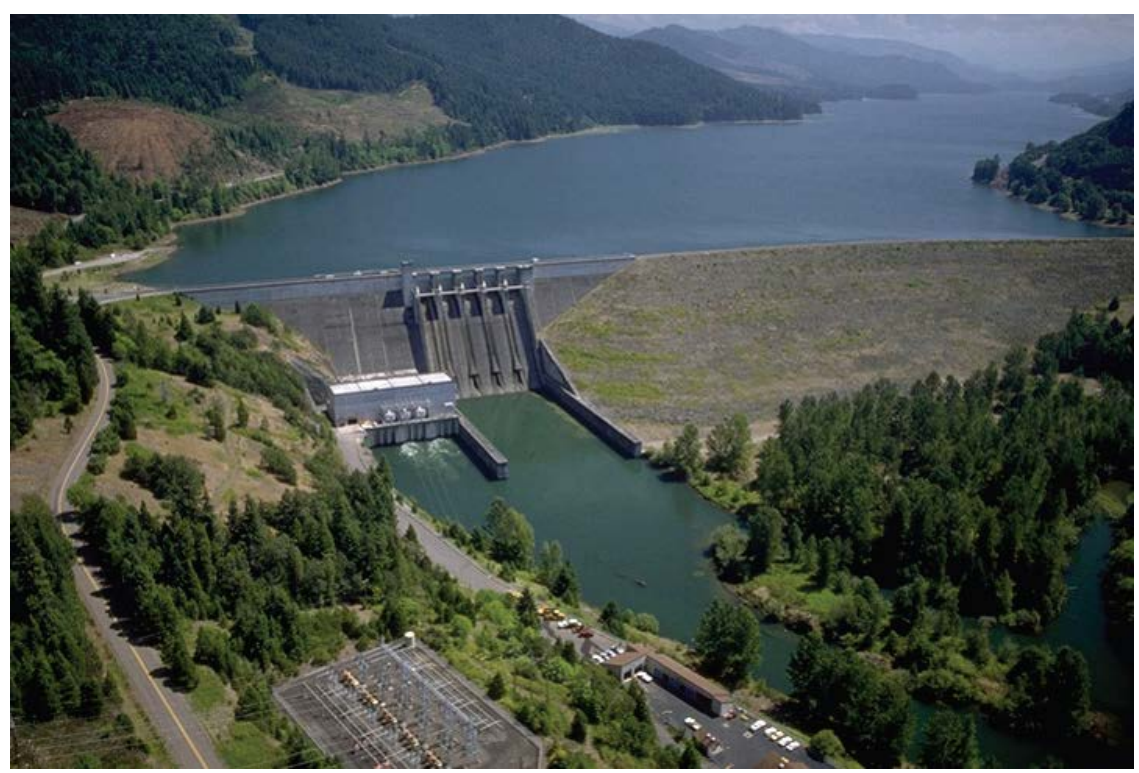

Figure 1.2. Aerial Photograph of Lookout Point Dam (courtesy of the USACE)

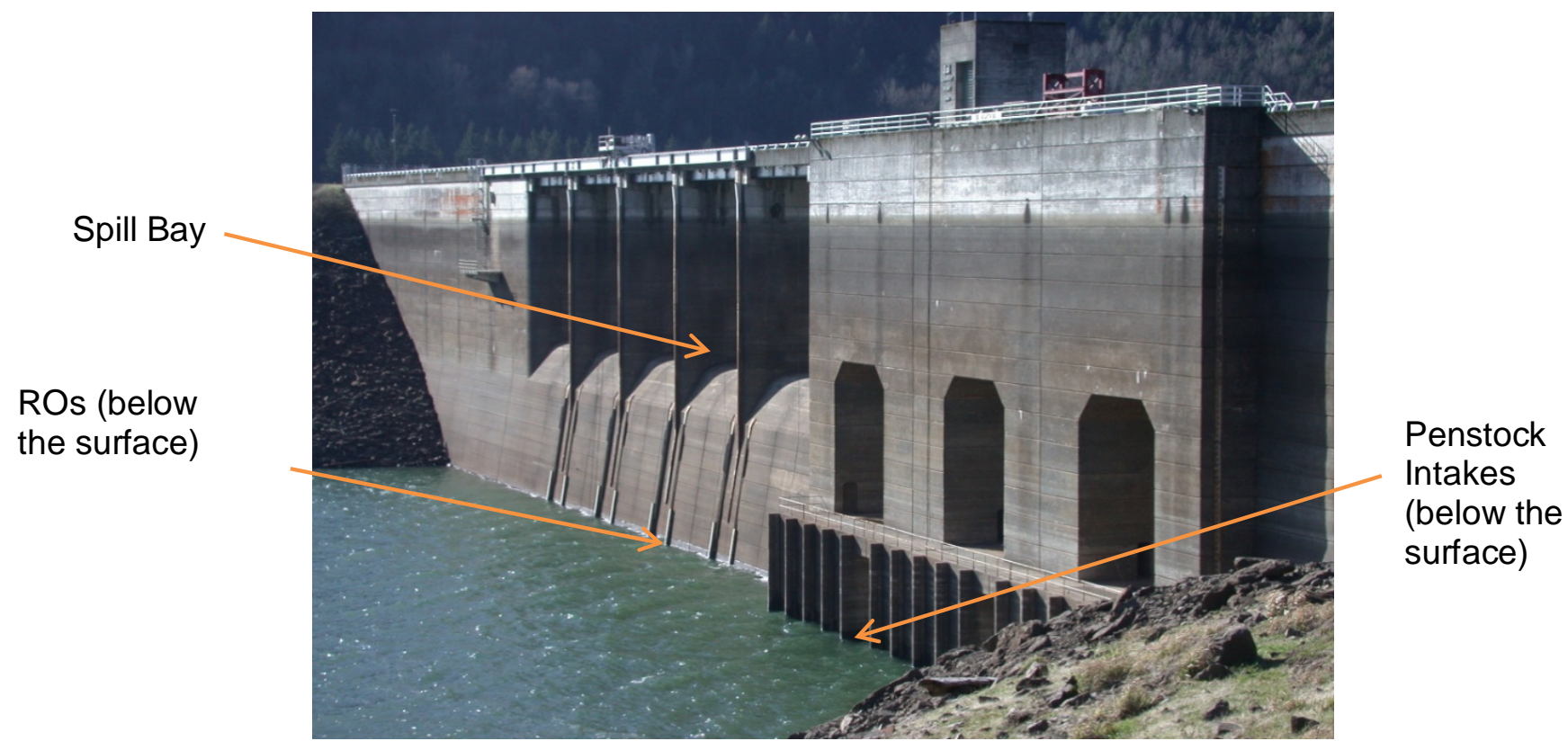

Figure 1.3. Upstream Face of LOP Showing Locations of the Penstocks, ROs, and Spill Bays

\subsection{Report Contents}

The ensuing sections of this report contain the study methods (Section 2.0), results (Section 3.0), discussion and recommendations (Section 4.0), and literature cited (Section 5.0). Appendix A contains the hydroacoustic system parameters. 


\subsection{Methods}

The general study approach, hydroacoustic systems, transducer locations and orientations, sampling design, and data processing and analysis are described in the following sections.

\subsection{General Approach}

The fixed-location hydroacoustic technique was used to accomplish the objectives of this study. This technique, conceived by Carlson et al. (1981) for single-beam acoustic systems, is described by Thorne and Johnson (1993). In addition to single-beam technology, split-beam technology is an important element of fixed-location hydroacoustics; MacLennan and Simmonds (1992) explain split-beam hydroacoustics. The general approach was to deploy a combination of single-beam and split-beam transducers to sample fish, and apply the acoustic screen model (Johnson 2000) to estimate fish passage rates and distributions. Split-beam data were used to estimate the average backscattering cross section of fish for detectability modeling and to determine the direction of fish travel through sampling volumes to allow for meeting the assumptions of the acoustic screen model. The methods used in this study were similar to those used in other USACE hydroacoustic studies (e.g., Johnson et al. 2005; Khan et al. 2009, 2010; Ploskey et al. 2003, 2005).

\subsection{Hydroacoustic Systems}

Data collection involved the use of one Precision Acoustic Systems (PAS) single-beam hydroacoustic system and two PAS split-beam systems. All systems operated at $420 \mathrm{kHz}$. The data-collection systems consisted of either Harp-1B (single-beam) or Harp-SB (split-beam) Data Acquisition/Signal Processing software installed on a data acquisition computer controlling a PAS-103 Multi-Mode Scientific Sounder. The PAS-103 sounders controlled transducers deployed in each penstock intake, above each RO entrance, and on the dam face. A total of nine transducers (two single beams and seven split beams) were deployed at the dam (Table 2.1). During data collection, all systems used a voltage output threshold range of -39 to $-56 \mathrm{~dB}$ re: $1 \mu \mathrm{Pa}$ at $1 \mathrm{~m}$. For perspective, a $-39 \mathrm{~dB}$ target strength can be obtained by ensonifying a 216mm fish within 15 degrees of dorsal aspect or a 300-m fish about 40 degrees off of dorsal aspect (Love 1977). Echo sounder transmission rates were 25 pps (pings per second) at the turbine penstock intakes, 33 pps at the ROs, and 20 pps for the dam-face transducers.

Table 2.1. Sample Locations and Spatial Sampling Intensity at Lookout Point Dam in 2010

\begin{tabular}{cccc}
\hline System & Location & Intensity by Unit & Number of Transducers and Beam Type \\
\hline $\mathrm{U}$ & Penstocks & 3 of 3 & 3 split-beam \\
$\mathrm{Q}$ & ROs & 4 of 4 & 4 split-beam \\
$\mathrm{H}$ & Dam Face & 1 of 1 & 2 single-beam \\
\hline
\end{tabular}




\subsubsection{Transducer Locations and Orientations}

We undertook a multi-step process from mount design to final system configuration. First, we developed designs for transducer mounts and had them reviewed and approved by the USACE engineers and project personnel. Second, field trials were undertaken to perfect the mount design. Third, aiming angles and ping rates were tested in the field. And, fourth, the optimum configuration for each hydroacoustic system was established with single- and split-beam transducers deployed to sample fish passage at the turbine penstock intakes, ROs, and dam face (vertical distribution). Transducer sampling volumes were positioned to minimize ambiguity in ultimate fish passage routes and the potential for multiple detections of the same fish. Johnson et al. (2010) documented the deployment and optimization for the hydroacoustic transducers at LOP during 2010.

\subsubsection{Turbine Penstock Intakes}

One split-beam transducer $\left(10^{\circ}\right)$ was installed inside each of the three turbine penstock intakes (Figure 2.1). Divers installed the transducers at the top of the fourth set of trash racks from the bottom (El. $804 \mathrm{ft}$ above msl; Figure 2.2). The transducer mounts were designed to fit between the vertical bars of the trash rack. This design allowed divers to secure the mount to the trash rack of each intake from the forebay. The transducer was aimed down at 42 degrees off horizontal. The presence of a head gate prevented the PNNL team from testing more than one aiming angle that was obtained from a scaled computer-aided drawing (Figure 2.3). After the divers finished the installation and the head gates were removed, a variety of ping rates were tested to select the best rate. We optimized the sampling rate at $25 \mathrm{pps}$ and each penstock intake was sampled for a total $20 \mathrm{~min} / \mathrm{h}$.

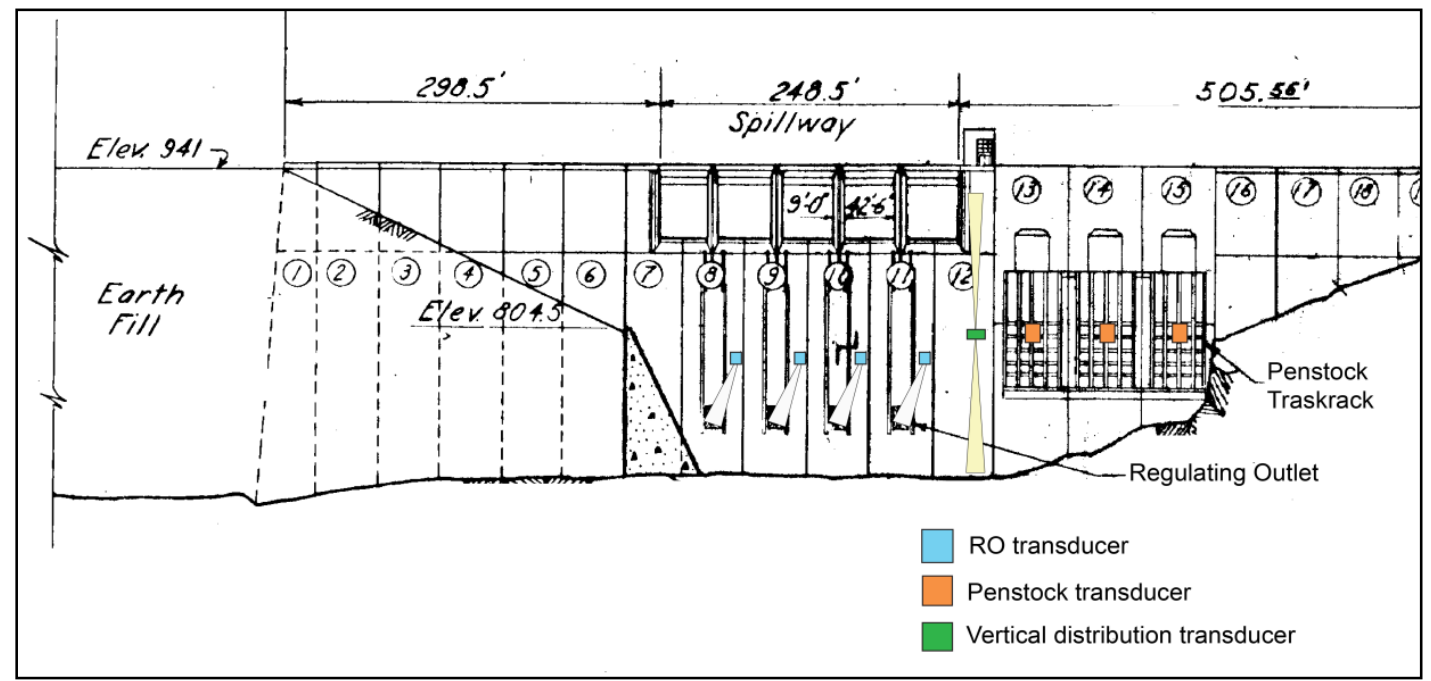

Figure 2.1. Front View of Lookout Point Dam Showing Approximate Transducer Locations (original drawing courtesy of the USACE) 


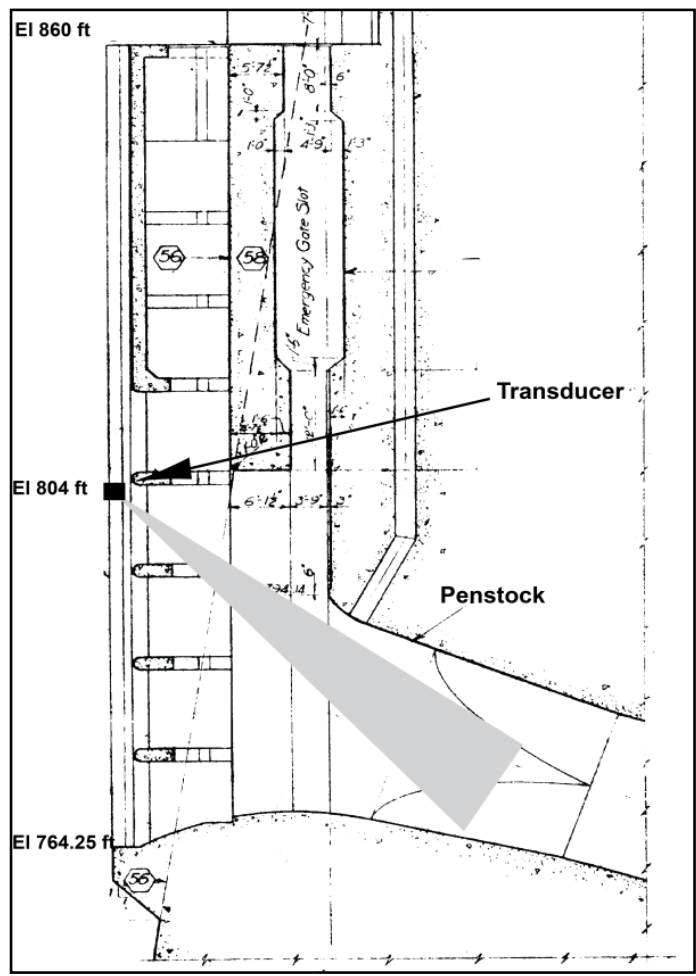

Figure 2.2. Cross-Sectional View of a Transducer Deployment at a Penstock Intake (original drawing courtesy of the USACE)

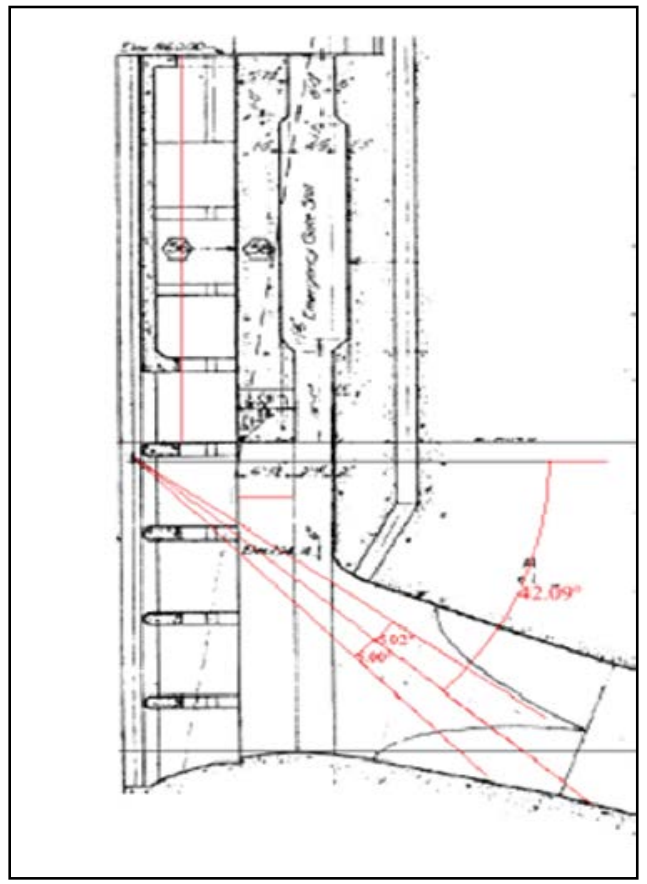

Figure 2.3. Cross-Sectional View of a Calculated Transducer Deployment Angle at a Penstock Intake (original drawing courtesy of the USACE) 


\subsubsection{Regulating Outlets}

One split-beam transducer $\left(10^{\circ}\right)$ was installed on the forebay face side of the dam at each of the four ROs (Figure 2.1). Divers installed the transducers at $28 \mathrm{ft}$ above and $2 \mathrm{ft}$ to the left (facing the dam) of each RO. The RO transducers were located at El. $764 \mathrm{ft}$ above msl. Each transducer mount was concrete anchored to the face of the dam. The transducers were aimed obliquely 19 degrees off vertical and 11 degrees off the face of the dam (Figure 2.4 and Figure 2.5). We optimized the sampling rate at 33 pps, and each RO was sampled for $15 \mathrm{~min} / \mathrm{h}$.

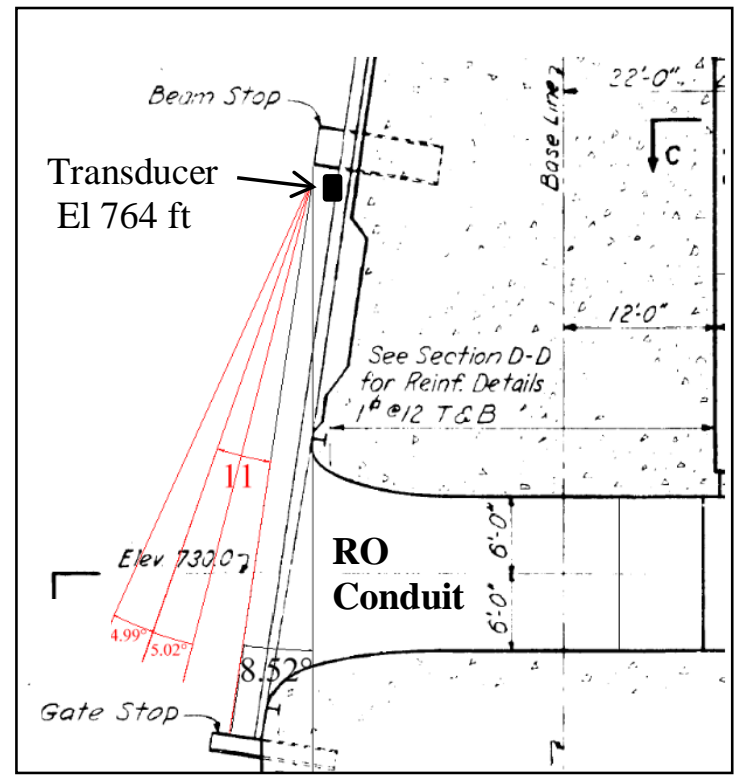

Figure 2.4. Cross-Sectional View of a Transducer Deployment with Calculated Angle at the RO (original drawing courtesy of the USACE)

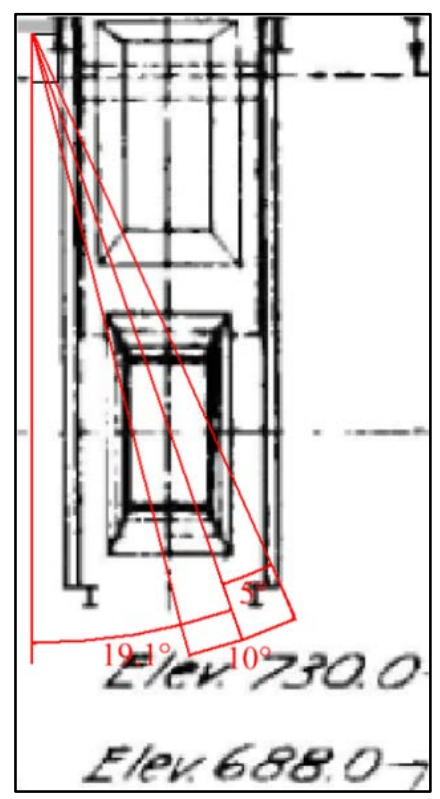

Figure 2.5. Front View Depicting the Orientation of a Transducer at an RO (original drawing courtesy of the USACE) 


\subsubsection{Forebay Dam Face}

A pair of 6-degree single-beam transducers, one up-looking and one down-looking, was installed on the face of the dam between the powerhouse and spillway to obtain vertical distribution information about juvenile fish near the face of the dam (Figure 2.1). Divers installed the transducers deployed at the midwater column at El. $823 \mathrm{ft}$ above msl. The mount was concrete anchored to the face of the dam. We optimized the sampling rate at $20 \mathrm{pps}$ and each transducer was sampled for a total of $30 \mathrm{~min} / \mathrm{h}$.

\subsection{Sampling Design}

Systematic samples of fish passage, i.e., same order among sampling locations each hour, were collected at 1-min intervals $24 \mathrm{~h} / \mathrm{d}$. Each location was sampled 15, 20, or 30 times per hour depending on the number of transducers connected to the echo sounder. The transducers at the turbine penstock intake and forebay dam face sampled continuously, except when data were downloaded (10-20 minutes per week). The RO transducers were interrogated only when the ROs were open, including brief time periods before and after RO operations.

\subsection{Data Processing and Passage Estimation}

The data processing and reduction methods used were similar to those used by Khan et al. (2009, 2010) and Johnson et al. (2005). After the acoustic echo data were collected in the field and archived, they were processed to extract fish tracks. At this stage in the analysis, we were careful to set the tracking parameters to include all fish at the expense of including spurious tracks. Next, to separate acceptable from unacceptable tracks, we filtered the data using fish track characteristics such as slope, speed, noise count average, and pulse width. For quality assurance, the data were manually checked to ensure that valid fish tracks remained after filtering.

Mean target strength, an indicator of fish size, was also used to distinguish fish targets. Recall, during data collection, the maximum target strength was $-39 \mathrm{~dB}$ re: $1 \mu \mathrm{Pa}$ at $1 \mathrm{~m}$ and the minimum target strength was $-56 \mathrm{~dB}$. During data analysis, we used the target strength (TS) measurement to select and perform separate analyses for two size classes of fish (these sizes are approximations):

- "smolt-size" fish: $-39 \mathrm{~dB}>\mathrm{TS}>-53 \mathrm{~dB}$, corresponding to $\sim 300 \mathrm{~mm}>\mathrm{X}>\sim 90 \mathrm{~mm}$

- “small-size” fish: $-53 \mathrm{~dB}>\mathrm{TS}>-56 \mathrm{~dB}$, corresponding to $\sim 90 \mathrm{~mm}>\mathrm{X}>\sim 65 \mathrm{~mm}$.

The small-size fish were analyzed separately to investigate the high numbers of fish observed in December-January and to provide improved understanding of passage and diel distribution of such relatively small fish over the entire study period. We approximated fish length from target strength (Love 1977) and likely ensonification aspect.

To overcome the lack of species discrimination in the hydroacoustic data, we originally proposed to use species composition data from USACE's tailrace screw traps to apportion the hydroacoustic estimates among species of fish captured in the traps. It turned out that the sampling regimes for each method are quite different and could not be synchronized, precluding species apportionment of the hydroacoustic data. Therefore, the hydroacoustic estimates include passage of some portion of non-salmonids. Yearling 
Chinook composed $89 \%$ of screw-trap catches in 2010. Assuming equal capture probabilities, the nonsalmonid proportion is likely $\sim 11 \%$ of total numbers.

The process used to estimate passage rates from filtered tracked fish involved spatial and temporal expansions of raw counts. Briefly, each fish track that survived the filtering process was weighted spatially to account for the sample width of the acoustic beam at the target's mid-range relative to the width of the depth bin it sampled; i.e., fish passage at unsampled portions of a passage route was estimated by extrapolating from the sampled portions. The sum of these weighted fish was then extrapolated temporally by the hourly sampling fraction (60/total minutes of sample time per hour per location). Project operations data provided by the USACE were used to identify times when passage routes were closed; only open routes were included in the analysis.

The hourly passage rate data for each transducer were used to estimate various performance metrics. Equations for each estimator follow. Let $x_{i j k y}$ be the expanded fish passage count in the $i^{\text {th }}$ transducer $(i=1, \ldots, x)$ during the $j^{\text {th }}$ hour $(j=1, \ldots, 24)$ of the $k^{\text {th }}$ day $\left(k=1, \ldots, d_{y}\right)$ during $y^{\text {th }}$ study period, where $d_{y}$ is the number of study-days in the $y^{\text {th }}$ study period.

Total juvenile-size fish passage count for the $y^{\text {th }}$ study period was estimated by the formula

$$
\mathrm{TP}_{y}=\sum_{i=1}^{6} \sum_{j=1}^{24} \sum_{k=}^{d_{y}} x_{i j k y}
$$

Daily juvenile-size fish count for the $k^{\text {th }}$ day in the $y^{\text {th }}$ study period for analysis of run timing was estimated by the formula

$$
\mathrm{DP} P_{k y}=\sum_{i=1}^{6} \sum_{j=1}^{24} x_{i j k y}
$$

Hourly juvenile-size fish count for the $j^{\text {th }}$ hour in the $y^{\text {th }}$ study period for analysis of diel distribution was estimated by the formula

$$
H P_{j y}=\sum_{i=1}^{6} \sum_{k=1}^{d_{y}} x_{i j k y}
$$

Johnson et al. (2005) describe methods to estimate variances for the passage rate estimates. The variances associated with each passage rate estimate were likely underestimated because between-intake variability in passage within a given turbine unit could not be accounted for because of sampling limitations. The $95 \%$ confidence intervals (CIs) for total and daily passage rates were calculated as follows:

$$
C I= \pm 1.96 * \sqrt{\text { Variance }}
$$


We used correlation and regression methods (Sokal and Rohlf 1981) to analyze relationships between total fish passage and total project discharge, forebay elevation, and change in forebay elevation. This study did not involve comparisons of experimental treatments.

\subsection{Regression Models and Akaike's Information Criterion}

Simple linear regression models were developed for fish passage (dependent variable) and total project discharge, forebay elevation, and forebay delta (independent variables). Fish passage data were log-transformed to improve distribution normality. Daily data were used in all regression analyses.

Multiple regression models were also developed to explore the relationships between fish passage and various environmental variables, including total project discharge, forebay elevation, forebay delta (dayto-day change in forebay water surface elevation, both magnitude and direction), water temperature (turbine outflow), Julian day, ${ }^{1}$ and study period. Models were compared amongst each other using Akaike's Information Criterion (AIC; Anderson et al. 1994). AIC is an a priori model-building process that compares different candidate models given a specified set of variables applied to an observation data set. It provides a unitless AIC score for each subset model that is built with the intent to avoid overparameterization in the model. The formula for an AIC score is

$$
\mathrm{AIC}=2 \mathrm{k}-2 \ln (\mathrm{L})
$$

where, $\mathrm{L}=$ maximized value of the likelihood function of the estimated model and $\mathrm{k}=$ number of parameters in the model.

The score reflects a trade-off between the lack of fit and the number of parameters in the model, and the preferred model is the one with the lowest AIC value, because it minimizes the information lost from the "true" unknown model. The model with the highest likelihood is the best fit to the observed data, although a model with fewer parameters or one having parameters carefully chosen to diminish correlation effects may be a better fit to the underlying phenomena. For example, when there is a high degree of correlation among variables in the model, the AIC score is lower and the $P$-value higher, but the strength of the effects is diminished by the presence of correlated variables. A low AIC score by itself does not indicate the real-world strength of the model's predictive power. Choosing models with more interaction terms can greatly expand understanding of the relationships among the variables in the model and allows more hypotheses to be tested. Candidate models having AIC values within 1-2 of the minimum AIC score are considered to have substantial support and can be evaluated further for final selection. The model-building output may provide more than one model within 1-2 AIC values of the minimum. The model chosen includes the constitutive terms from any interaction terms, as recommended by Brambor et al. (2006).

The candidate models for predicting fish passage were built using Generalized Linear/Nonlinear Regression techniques in Statistica version 10.0 (www.statsoft.com) to create and evaluate the best subsets of explanatory variables. The many possible models were evaluated using AIC. Where necessary, variables were transformed $(\log 10)$ to reduce departures from a normal distribution. Total project discharge and total fish passage were transformed to log10 values. Forebay elevation delta,

\footnotetext{
${ }^{1}$ Julian day values during January 2011 were continued from December 2010, i.e., 366, 367, 368,...
} 
existing as positive and negative changes in elevation, ${ }^{2}$ was decomposed into two variables - one a categorical variable with values of either 1 or 0 to indicate either positive increase in forebay elevation or no increase, and the other a continuous variable taking the log10 of the absolute value of forebay elevation delta. AIC multiple regression assumes normal distribution of residuals. We used the distribution-fitting option in Statistika and fit parameters to a normal curve where fitting resulted in markedly improved chi square values. The variables that were improved when transformed to log10 values were discharge (greatly improved) and forebay elevation delta, which improved greatly when the $\log 10$ of the absolute value was taken.

To avoid including highly correlated dependent variables in the model, correlation among variables was examined. Where independent variables are highly correlated the coefficient estimates can change erratically in response to small changes in the model or data. Bivariate scatterplots were also produced to examine relationships among variables.

Many different sets of models were run to include different groupings of variables because using all variables at once was beyond the capabilities of the software program. For each set, the full model was specified to include two-way interactions of continuous variables. The best subsets of those model terms were run and ranked by their AIC scores. From the set of models with AIC scores within 2 of the minimum AIC value, we selected models that included each original variable, which was included in an interaction term. The selected model was evaluated for its ability to predict passage. The model equation result is the inverse of the natural log of the predicted value, in the form

$$
\text { Expected value }=\exp \left(\mathrm{B}_{0}+\mathrm{B}_{1} * \mathrm{~V}_{1}+\mathrm{B}_{2} * \mathrm{~V}_{2} \ldots \ldots+\mathrm{B}_{\mathrm{n}} * \mathrm{~V}_{\mathrm{n}}\right)
$$

To model the expected value of daily fish passage at LOP for 2010, the following variables were used in the multiple regressions: Julian day, daily total project discharge (log10-transformed), daily average forebay elevation, forebay delta magnitude (log10-transformed), and forebay delta direction and two-way interactions of all continuous variables. Water temperature was not included because the software program would not run with both Julian day and water temperature in the set with all the other variables, and Julian day and water temperature were significantly correlated.

\footnotetext{
${ }^{2}$ Positive delta means forebay elevation was increasing; negative delta means forebay elevation was decreasing.
} 


\subsection{Results}

The results from the study are presented in two sections: dam operations and fish passage and distribution.

\subsection{Dam Operations}

Dam operations data include forebay elevation and turbine and RO discharge. Dam operations data provide context for the fish passage and distribution results. In the results sections that follow, data are presented separately for seven periods based on dam operations:

- Refill (March 1 - May 8)

- Full Pool (May 9 - June 6)

- Summer Release (June 7 - July 31)

- Flat Elevation (August 1 - September 4)

- Fall Release (September 5 - October 23)

- Fall Rains (October 24 - November 30)

- Winter (December 1 - January 31).

\subsubsection{Forebay Elevation}

The forebay elevation of LOP follows a "rule curve" managed by the USACE Reservoir Control Center. The "rule curve" dictates lowering the forebay pool elevation in the fall and winter months to prepare for storage and flood control in the spring and summer months. Generally, the fall drawdown of the pool begins after September 1, and refill begins on or around February 1. In 2010, the forebay surface elevation began to increase in early February, peaked on June 5 (El. $901 \mathrm{ft}$ ), decreased through July, held at approximately El. $849 \mathrm{ft}$ above msl through August, and decreased for the fall drawdown from September 3 through October (Figure 3.1). A scheduled maintenance of the penstock head gates of turbine units 1 and 2 in August required drawing down the forebay pool to approximately El. $849 \mathrm{ft}$ above msl by the end of July to facilitate the work. The pool was held steady at El. $849 \mathrm{ft}$ above msl for the month of August. From late October to the end of the study period on January 31, forebay elevation fluctuated due to runoff from winter storm events. The minimum pool elevation for the study period was on October 23 (El. $827 \mathrm{ft}$ above msl). 


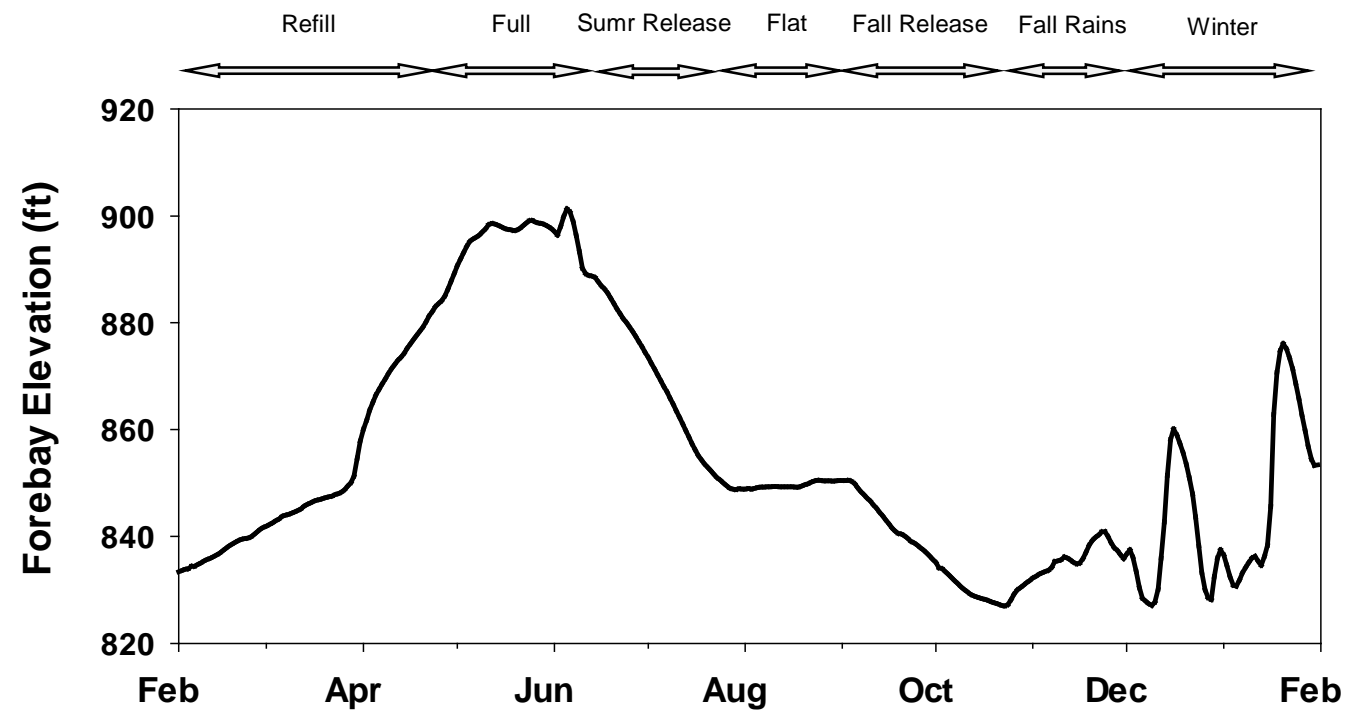

Figure 3.1. Daily Average Surface Elevation (ft above msl) of the Forebay at LOP from February 2010 through January 2011 During Each of the Seven Periods Listed Above. Data were obtained from the USACE Willamette Valley Project Operations Office.

\subsubsection{Turbine and RO Discharge}

During our study, average daily turbine discharge remained fairly constant ( 1.25 kcfs) from February until May (Figure 3.2). From May 2 onward, turbine discharge increased, reaching a maximum total discharge on June 5 (8.83 kcfs). From June 11 through 13 no turbines were operated, and the ROs were opened from June 2 through 14. Afterwards, turbine discharge generally decreased until leveling off in October ( 1.40 kcfs). From November 9 until the end of the study period on January 31, turbine discharge was generally high and fluctuated widely due to rain events. An especially large peak occurred on January 26 (8.70 kcfs). The ROs were opened on November 24 and likewise experienced large fluctuations in daily discharge until the end of the study period. 


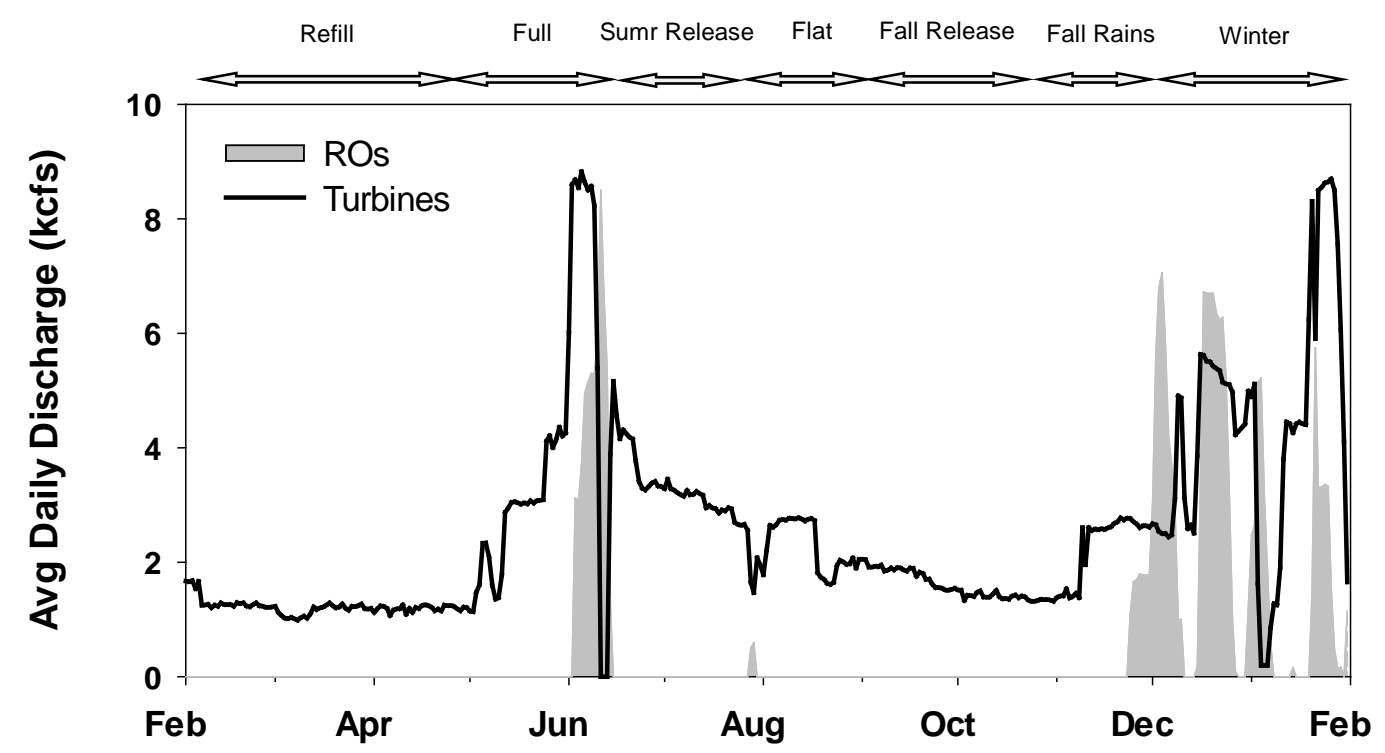

Figure 3.2. Average Daily Discharge for the Turbines and Regulating Outlets at LOP from February 2010 Through January 2011 During Each of the Seven Periods Listed Above. Data were obtained from the USACE Willamette Valley Project Operations Office.

Between February and May, LOP turbines typically were operated for power-peaking during the morning ( 0600-0900 h) and evening ( 1700-2200 h), although operations at other times also occurred (Figure 3.3). During May to mid-August, the turbines were operated continuously, except for a few days when power was not generated (June 11 through 13), and the ROs were used to pass water through the dam. Power-peaking resumed in mid-August, occurring during the day ( 0400-2200 h) for the last 2 weeks of August and during the morning ( 0500-1200 h) and evening ( 1600-2200 h) from September through October. The turbines were operated continuously through the winter months, except for a few days (January 7 through 11) when power-peaking occurred or turbines were stopped momentarily.

Turbine operations varied by units and hours throughout the year, depending on power demand and maintenance schedules (Figure 3.3). Generally, all three turbines were used from March 1 to August 2. Turbine usage was low (less than $10 \mathrm{~h} / \mathrm{d}$ ) to moderate (11 to $20 \mathrm{~h} / \mathrm{d}$ ) until June. On June 2 through 9, all three turbines were operated continuously, and from June 11 through 13, all three were inactive. For the rest of June and through July, turbine operations varied in usage and duration. From August 3 onward, only turbine unit 3 was operated, and its use was moderate to heavy. Turbine unit 1 began operation on December 8 and unit 2 on January 18. 

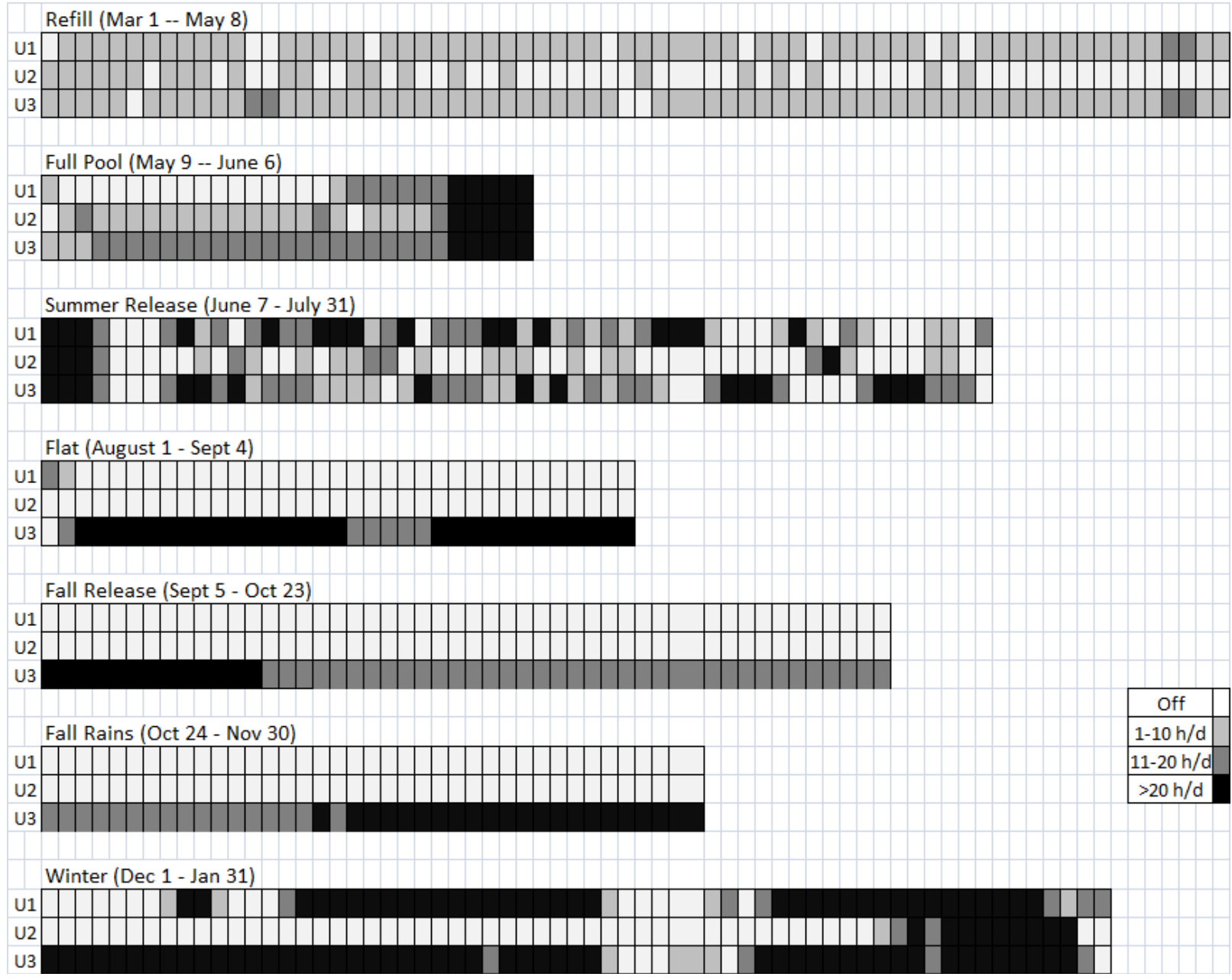

Figure 3.3. Turbine Operations from February 2010 through January 2011. The columns in the grid represent 24-h periods. Data were obtained from the USACE Willamette Valley Project operations office.

\subsection{Fish Passage and Distribution}

Although we could not apportion the hydroacoustic estimates by species composition from the screwtrap data, the trap data provide useful evidence of the species composition of fish passing the dam that the hydroacoustic sampling would have detected. The overall catch in the tailrace screw traps during 2010 sampling was composed of 11 species (Keefer et al. 2011): black crappie (Pomoxis nigromaculatus), bullhead spp. (Ameiurus spp.), bluegill (Lepomis macrochirus), Chinook salmon (marked and unmarked), largemouth bass (Micropterus salmoides), largescale sucker (Catostomus macrocheilus), northern pikeminnow (Ptychocheilus oregonensis), rainbow trout (O. mykiss), sculpin spp. (Cottus spp.), redside shiner (Richardsonius balteatus), and white crappie (P. annularis). The Oncorhynchus species and most of the centrarchids were juveniles. Juvenile Chinook salmon dominated the catch during 2010 sampling (88.6\%). The next most abundant fish was white crappie, which is acoustically similar to juvenile salmonids. Passage timing data and run size estimates from the screw-trap effort are discussed with the hydroacoustic results in Section 4.0. 
The fish passage results are organized into four sections corresponding to the objectives (Section 1.2): 1) turbine penstock intakes - smolt-size fish; 2) turbine penstock intakes - small-size fish; 3) regulating outlets - smolt-size fish, and 4) vertical distribution - small-size and smolt-size fish.

\subsubsection{Turbine Penstock Intakes - Smolt-Size Fish}

\subsubsection{Passage Estimates and Run Timing}

Over the entire March-January study period, run timing for smolt-size ${ }^{1}$ fish peaked in mid-December (Figure 3.4). Downstream passage of these juvenile fish occurred throughout most of the study period, but numbers were low (zero to <100) for most of the spring and summer, except for early April and again for a few days in June and July when pulses greater than 300 fish/d and up to 1,415 (June 27) were observed. Passage rates began to increase in the fall, starting on October 28 when a pulse of 2,561 fish passed the dam. Passage rates remained high throughout the winter, averaging 1,254 fish/d. It is likely many of these fish were not juvenile salmonids because thousands of juvenile white crappie were captured in the screw traps in the LOP tailrace during December 2010 and January 2011 (Chad Helms, USACE, personal communication, unpublished data). A run-timing curve for only March-November clearly shows peaks in early spring, early summer, and late fall (Figure 3.5).

During the entire study period, an estimated total of 142,463 fish $\pm 4,444$ (95\% CI) smolt-size fish passed through turbine penstock intakes. However, not counting the December-January months, the estimated total passage at LOP (March-November) was 22,442 fish \pm 3,095.

\footnotetext{
${ }^{1}$ Note that while we can discriminate between size classes of fish, we cannot discriminate between salmonid species and non-salmonid species in these hydroacoustic data.
} 


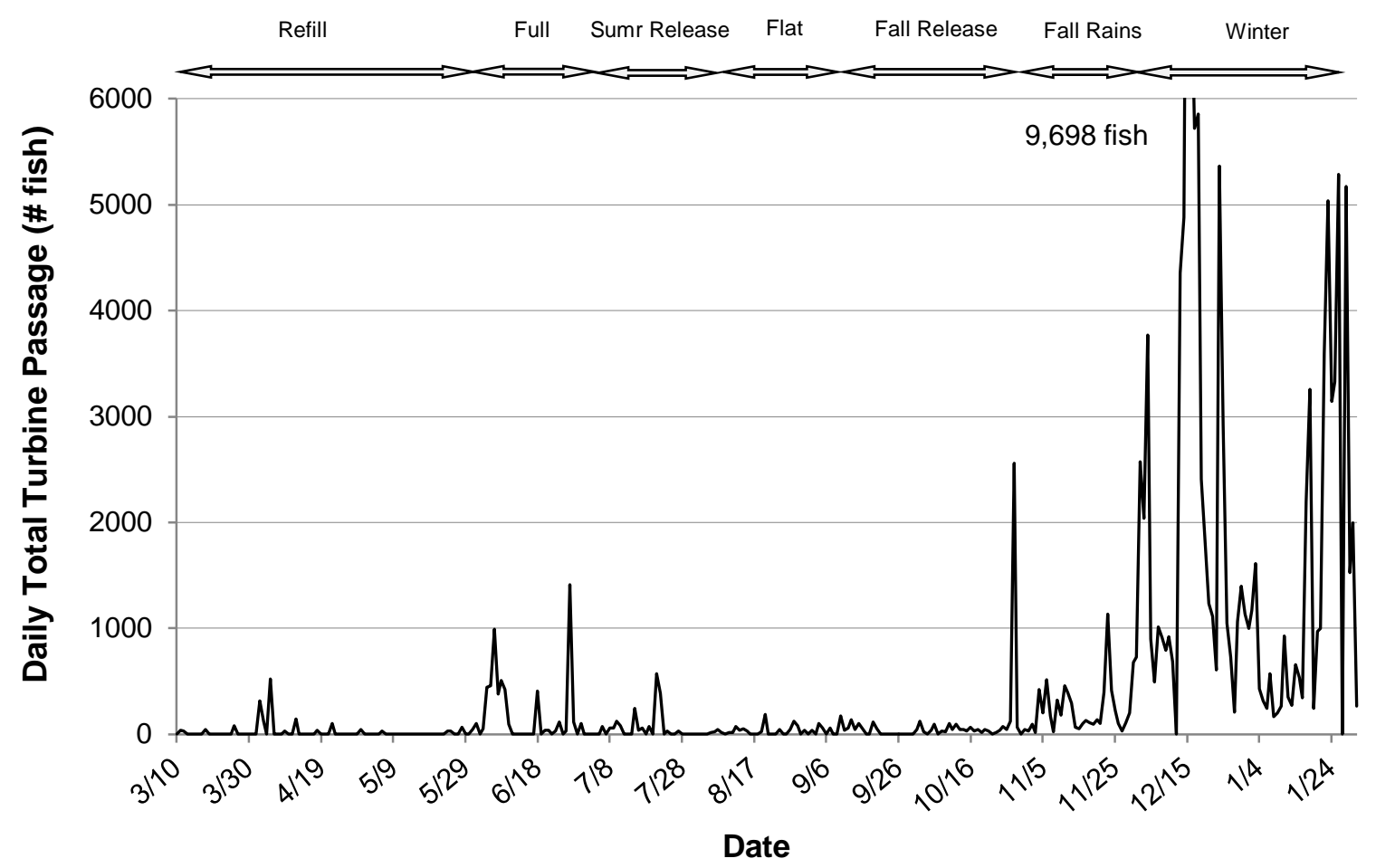

Figure 3.4. Estimated Daily Passage of Smolt-Size Fish at LOP Turbine Penstock Intakes from March 10, 2010 through January 31, 2011

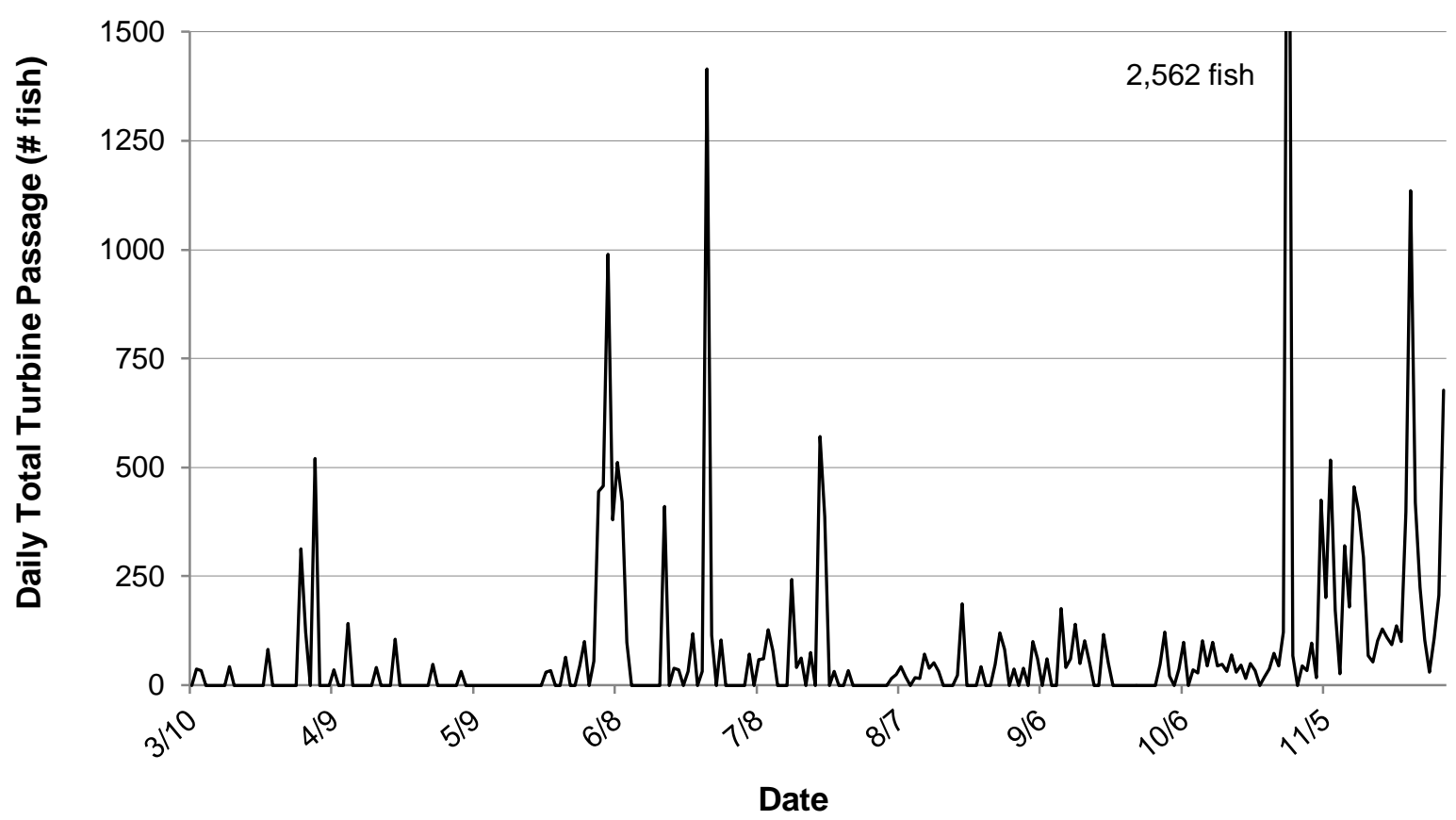

Figure 3.5. Estimated Daily Passage of Smolt-Size Fish at LOP Turbine Penstock Intakes from March 10 through November 30, 2010 


\subsubsection{Horizontal Distribution}

Horizontal distribution for a period when all three turbine units were operated and appreciable numbers of fish were passing the dam indicates a fairly uniform distribution of fish passage (Figure 3.6). Intake 2 passed the most fish and Intake 3 passed the second highest number (Figure 3.6). Each intake passed about the same amount of water because all three were operating the same amount of time.

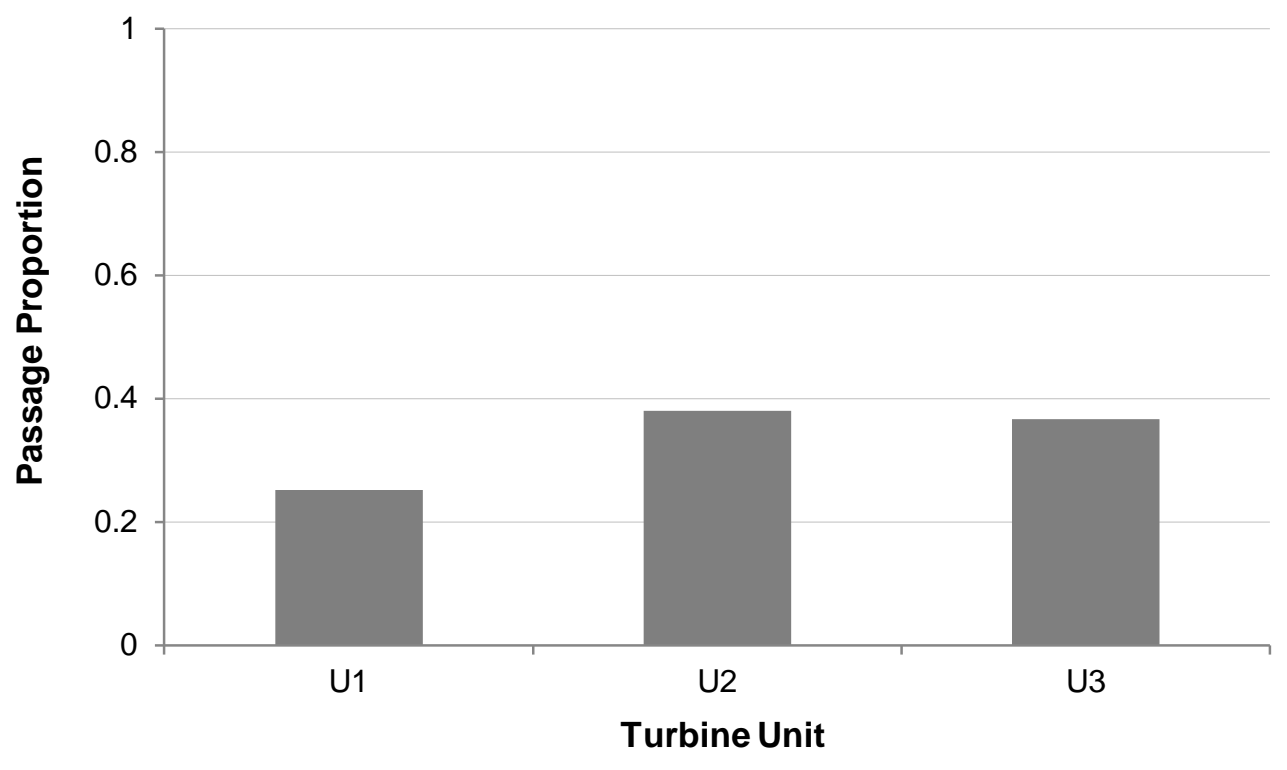

Figure 3.6. Horizontal Distribution of Smolt-Size Fish Passage at the Turbine Penstock Intakes When All Three Units Were Operating and Fish Passed All Units (January 28-29, 2011)

\subsubsection{Diel Distribution}

Diel distributions for smolt-size fish reveal distinct peaks during morning hours for most of the seven periods of dam operations (Figure 3.7). Evening peaks are also evident in some periods (Refill, Fall Rains, and Winter) but not in the others. Generally, diel passage patterns for smolt-size fish did not follow diel discharge patterns, except for the Refill and Winter periods (Figure 3.7). 

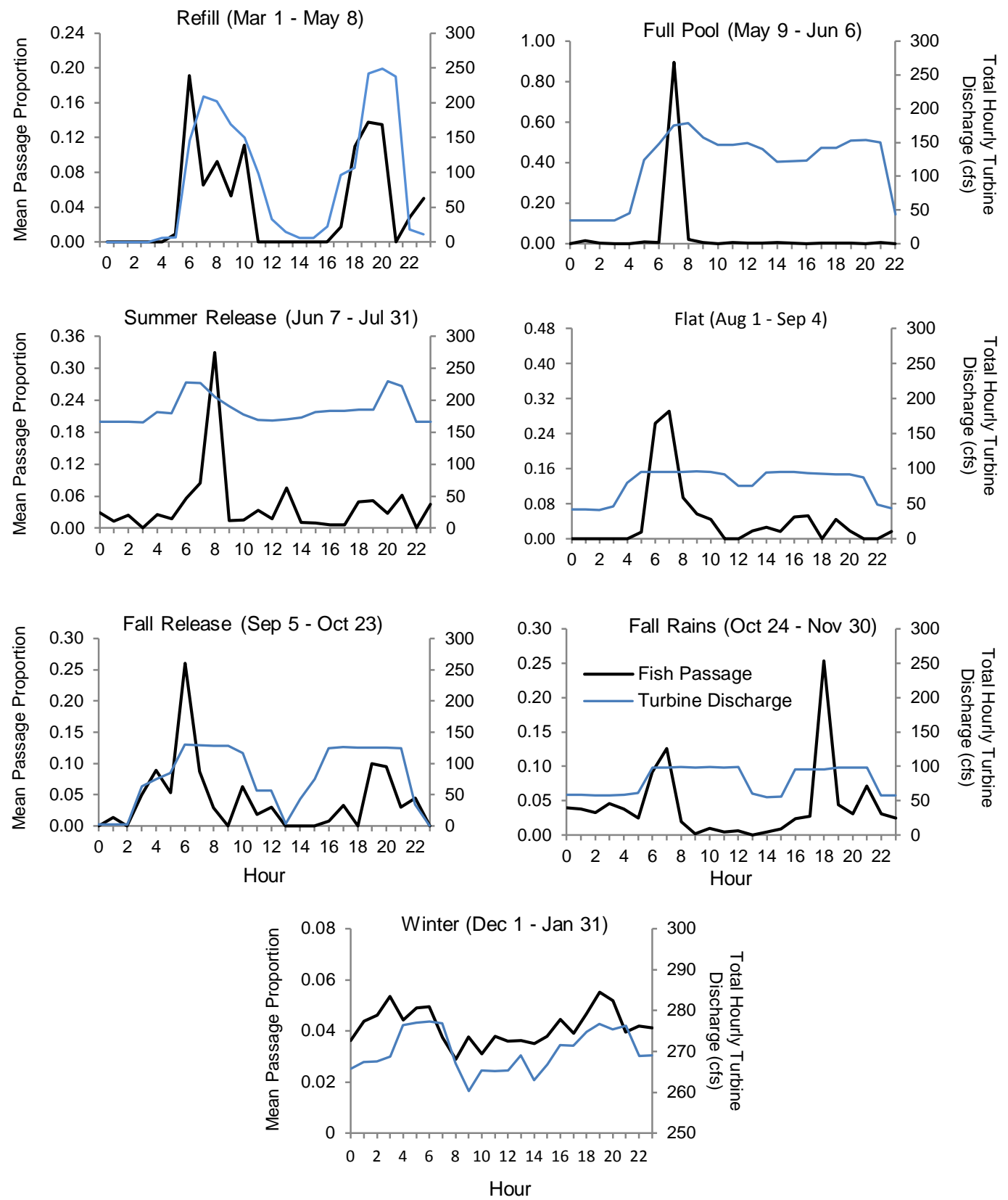

Figure 3.7. Diel Distribution of Smolt-Size Fish Separately for the Seven Dam Operations Periods. Fish data (black lines) are presented as the hourly proportions of total passage. Total hourly turbine discharge (blue lines) (cfs) is also presented.

\subsubsection{Turbine Penstock Intakes - Small-Size Fish}

\subsubsection{Passage Estimates and Run Timing}

Run timing for small-size fish peaked (702 fish) on December 18 (Figure 3.8). Downstream passage of these small juvenile fish occurred on 2 days in the spring (March 11 and April 4), 8 days in the 
summer, and throughout late fall and winter. A total of 7,017 \pm 690 (95\% CI) small-size fish passed through the penstock intakes during the study period ${ }^{2}$.

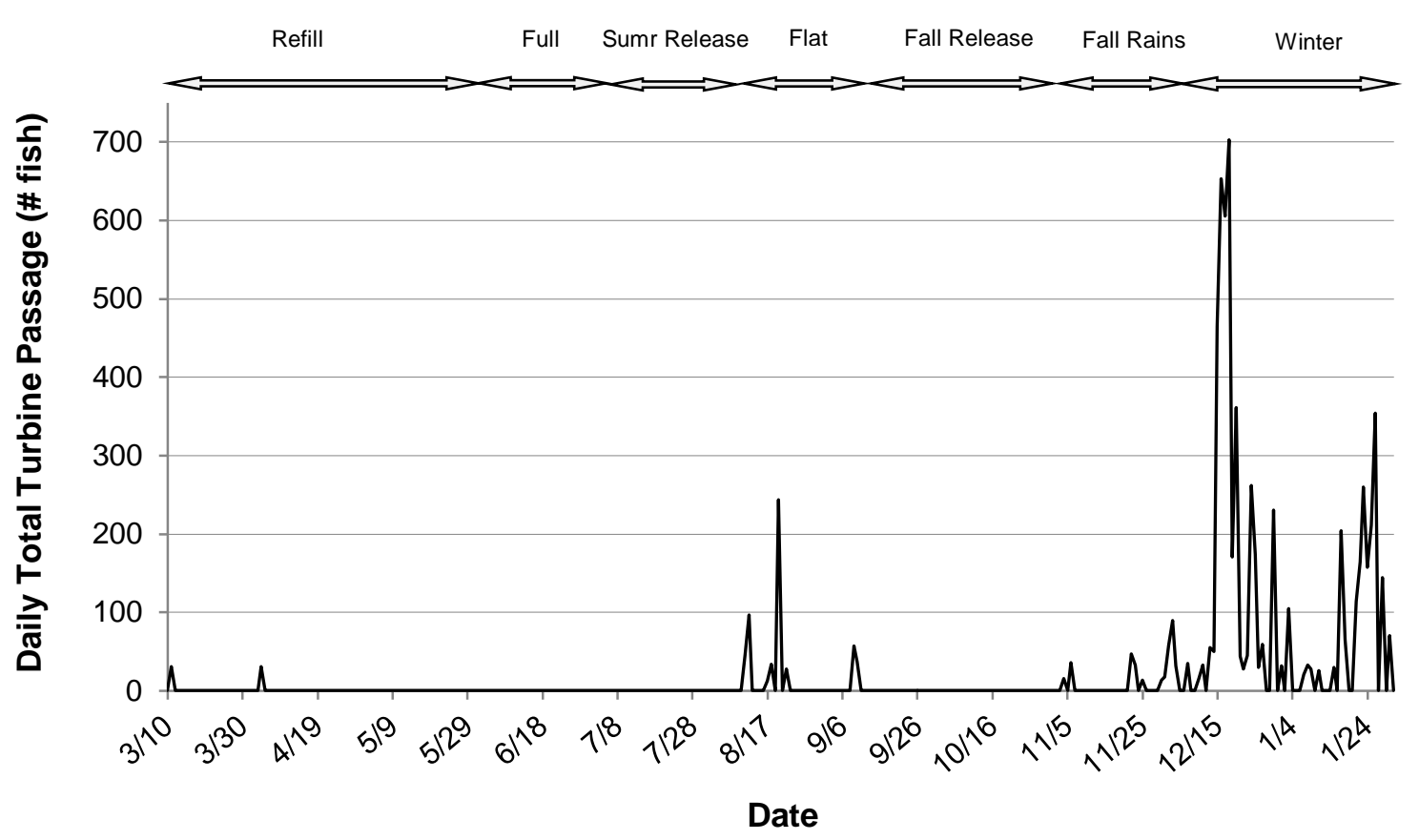

Figure 3.8. Estimated Daily Passage of Small-Size Fish at LOP Turbine Penstock Intakes from March 10, 2010, through January 31, 2011

\subsubsection{Diel Distribution}

Diel distribution data indicate small-size fish passed the dam in the morning and evening during spring months (Refill period), morning only in the summer and early fall during the Flat Elevation and Fall Release periods, and evening only in late fall during the Falls Rains period. Diel passage during the Winter period showed no patterns (Figure 3.9). Small-size fish did not pass the dam between May 9 and July 31 (Full Pool and Summer Release periods); therefore, diel results are not reported for these periods.

\footnotetext{
${ }^{2}$ Crappie $>200 \mathrm{~mm}$ in length were captured in the screw traps, although many were $<130 \mathrm{~mm}$ in length (C. Helms, personal communication). It is probable many crappie were larger than the small-size fish class we designated (65-90 mm).
} 

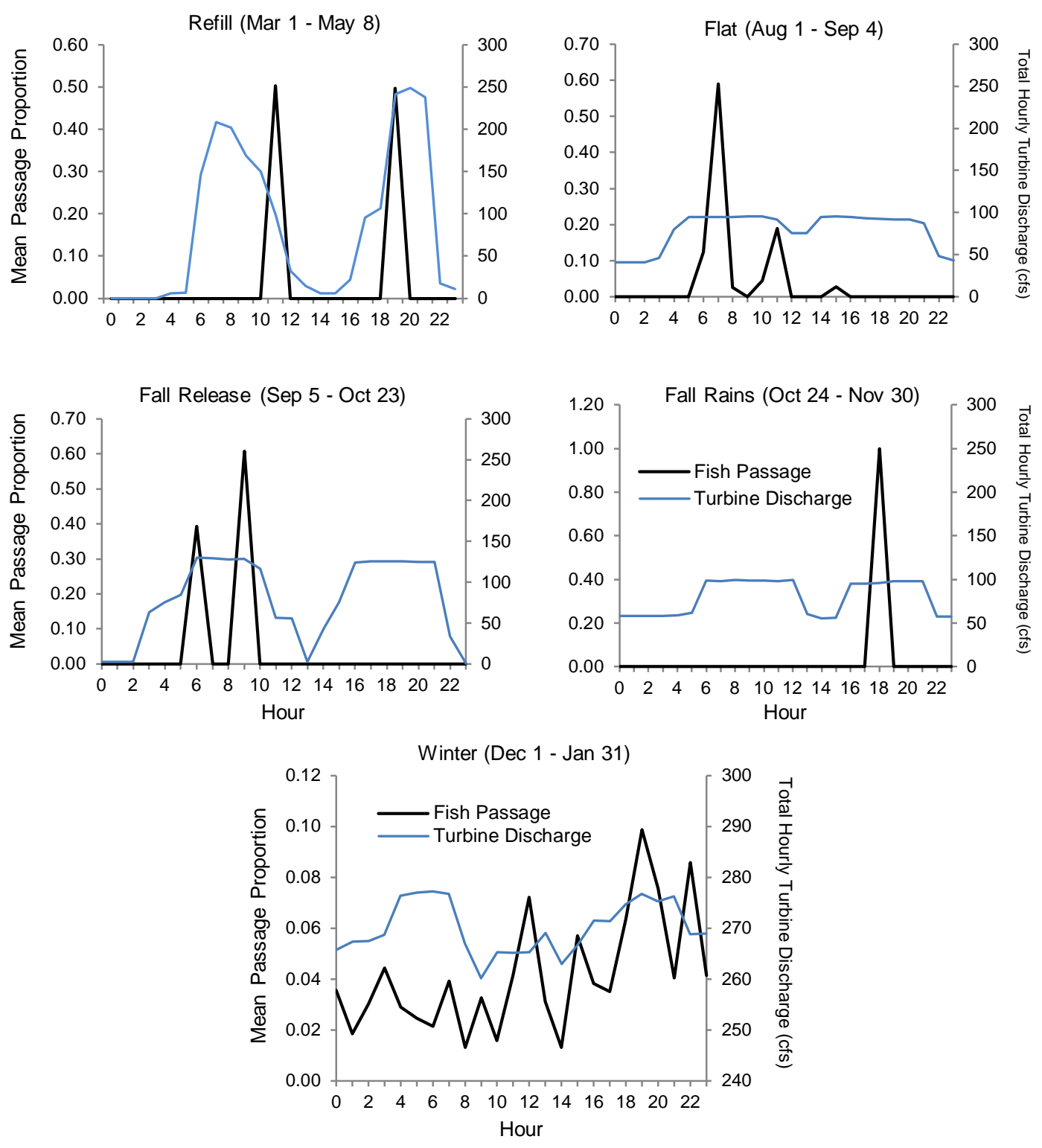

Figure 3.9. Diel Distribution of Small-Size Fish Separately for Five of the Seven Dam Operations Periods. No small-size fish passed the penstocks during the Full Pool and Summer Release periods. Total hourly turbine discharge (cfs) is also presented.

\subsubsection{Relationships between Fish Passage and Environmental Variables}

Linear and multiple regression techniques were used to study relationships between fish passage and environmental variables. First, though, correlations among variables were explored. Fish passage (logtransformed) was significantly $(P<0.05)$ correlated with all environmental variables except forebay elevation, forebay delta, and direction forebay delta (Table 3.1). Total project discharge was significantly correlated with all variables. Other correlations were mixed in significance. Scatterplots of all twovariable combinations show patterns in the structure of these bivariate data (Figure 3.10). For example, water temperature versus forebay elevation indicates low temperatures occurred over a wide range of forebay elevations and, at times, several water temperatures were observed for a given forebay elevation over the course of the study year. The bivariate plots show the complexity in the data. 
Table 3.1. Correlation Table for Variables from LOP Hydroacoustic Study 2010. Red font indicates significant correlation between variables $(P<0.05)$.

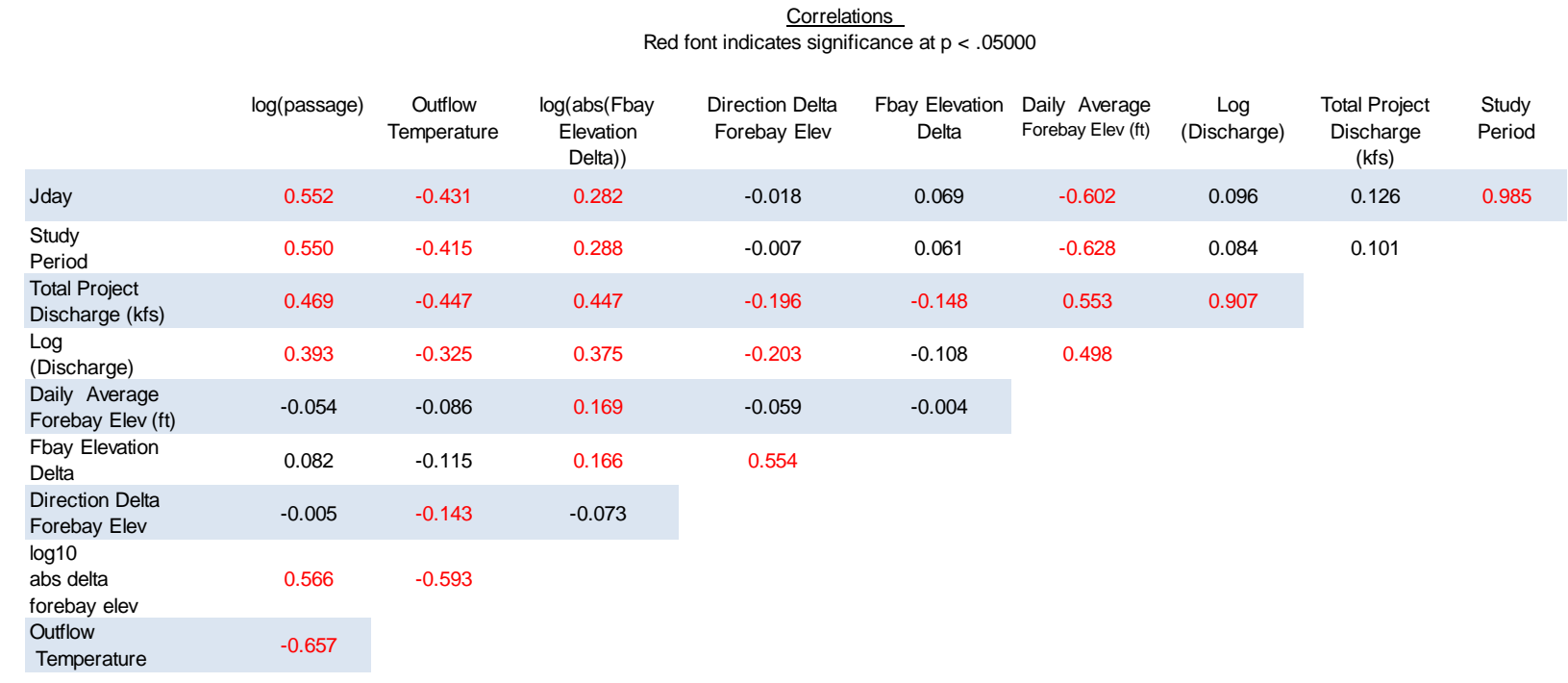



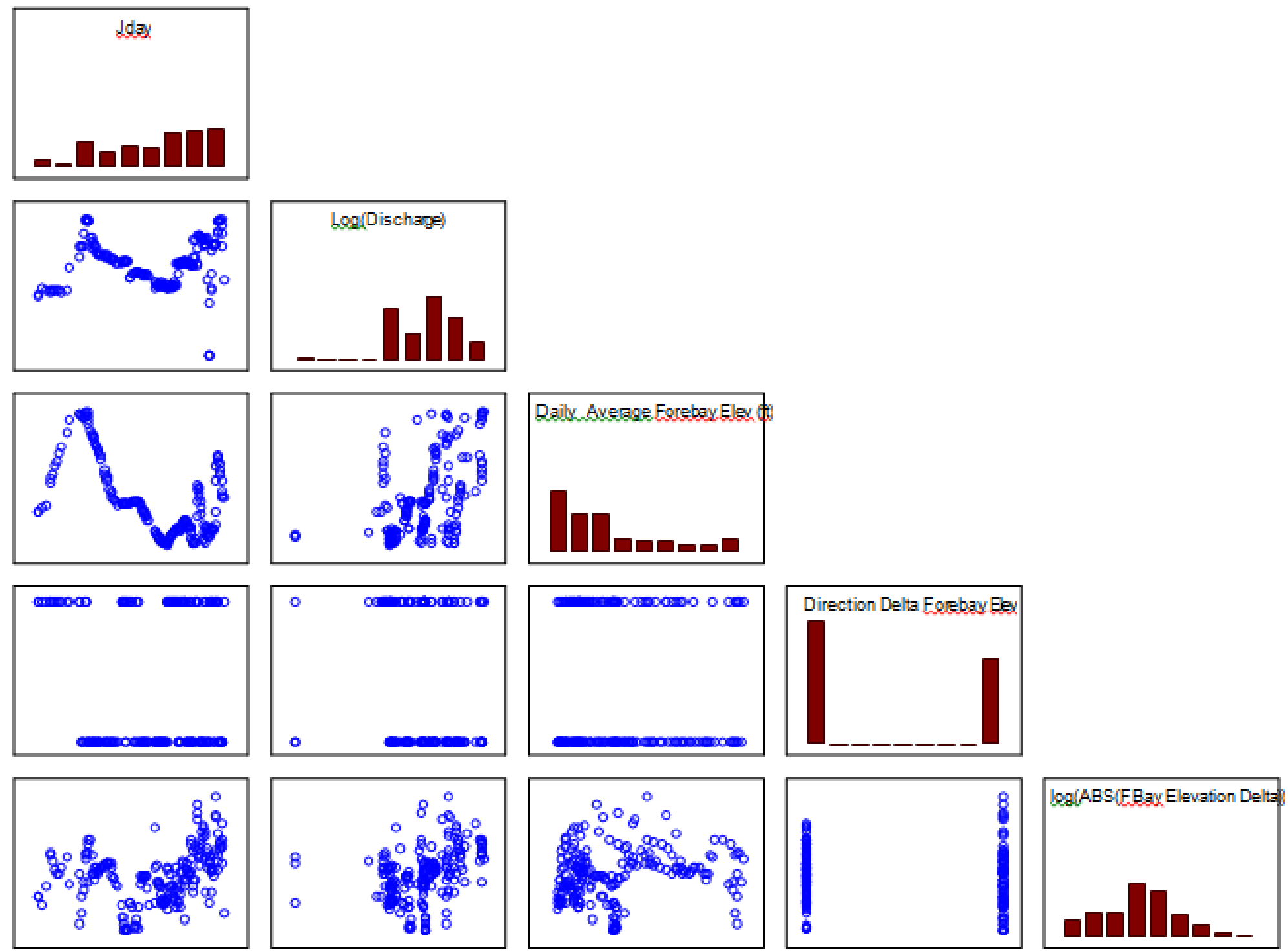

Figure 3.10. Matrix of Bivariate Scatterplots for Variables Used in the Multiple Regression (see Section 3.2.3.2). The bar graphs indicate the frequency distribution for the variable. Plot axes are determined by the column (x-axis) and row (y-axis) in the matrix. 


\subsubsection{Linear Regression}

We observed the highest fish passage rates in December-January when dam operations were most variable (Figure 3.11). Total project passage (turbines and ROs combined) for smolt-size fish was significantly related to project discharge $(P<0.001)$ (Figure 3.12). This relationship was positive. However, there was no relationship between total project passage and forebay elevation $(P=0.48$; Figure 3.13) or forebay elevation delta ( $P=0.16$; Figure 3.14).

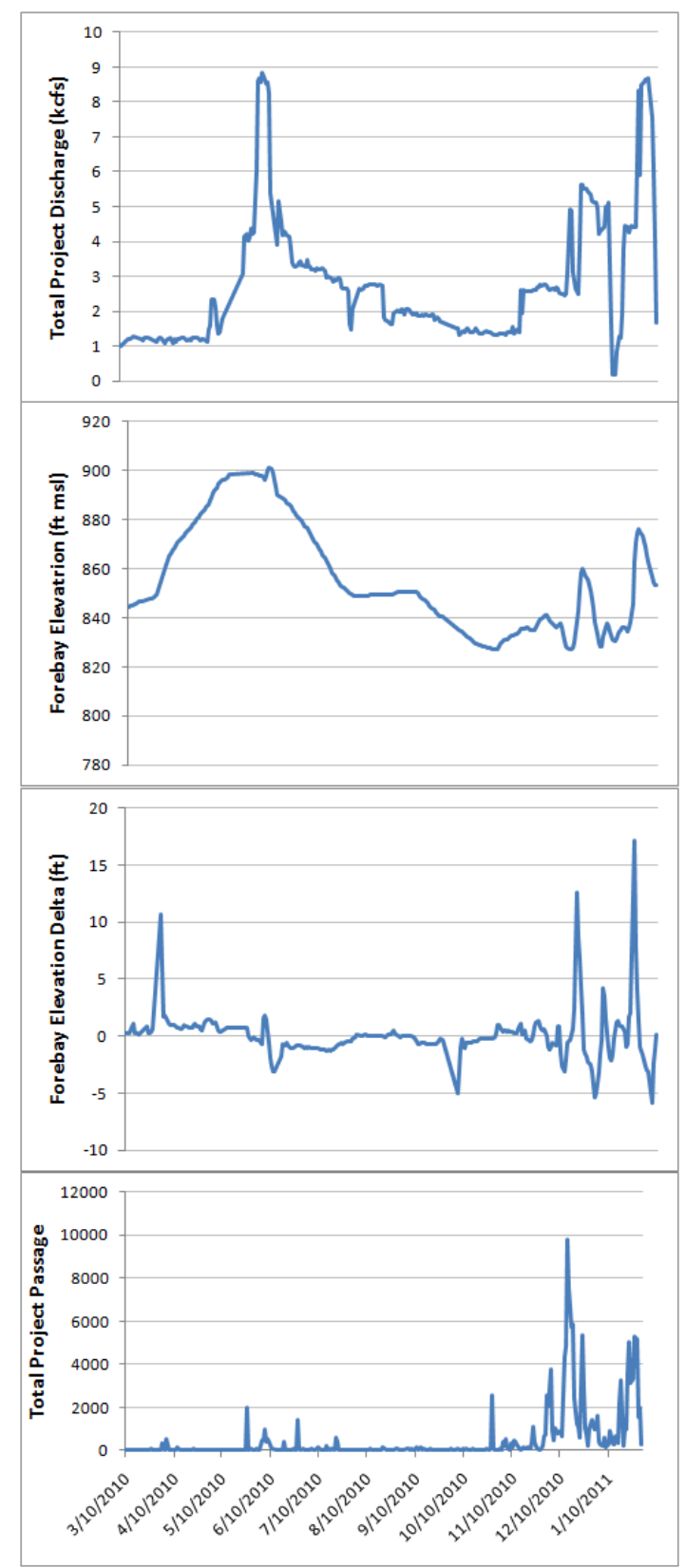

Figure 3.11. Daily Distribution During March 10, 2010 to January 31, 2011 for Total Project Discharge (top), Forebay Elevation (ft above msl; second from top), Forebay Elevation Delta (ft; second from bottom), and Total Project Passage for Smolt-Size Fish 


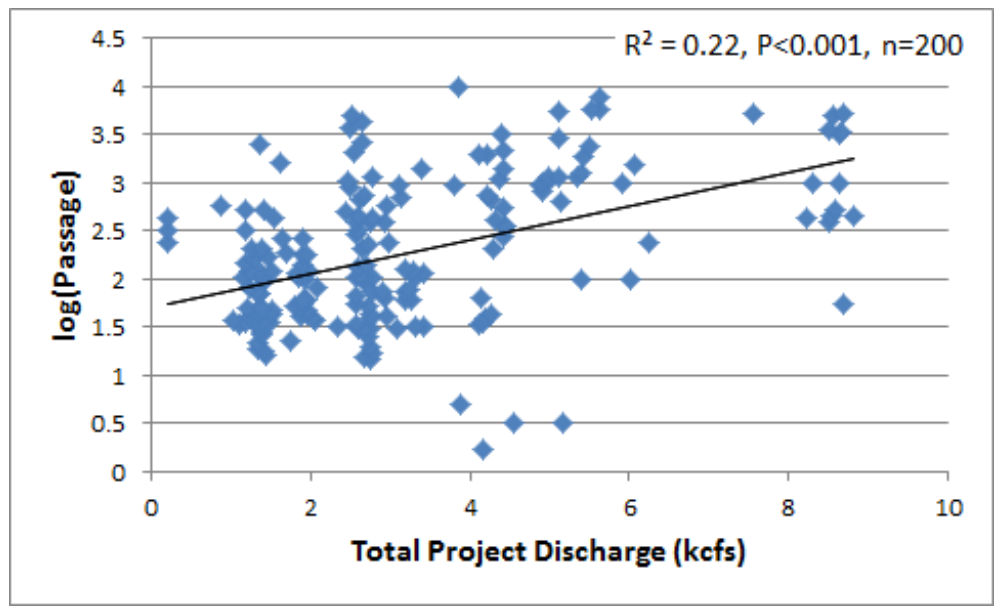

Figure 3.12. Relationship between Passage for Smolt-Size Fish (log10-transformed) and Total Project Discharge (kcfs)

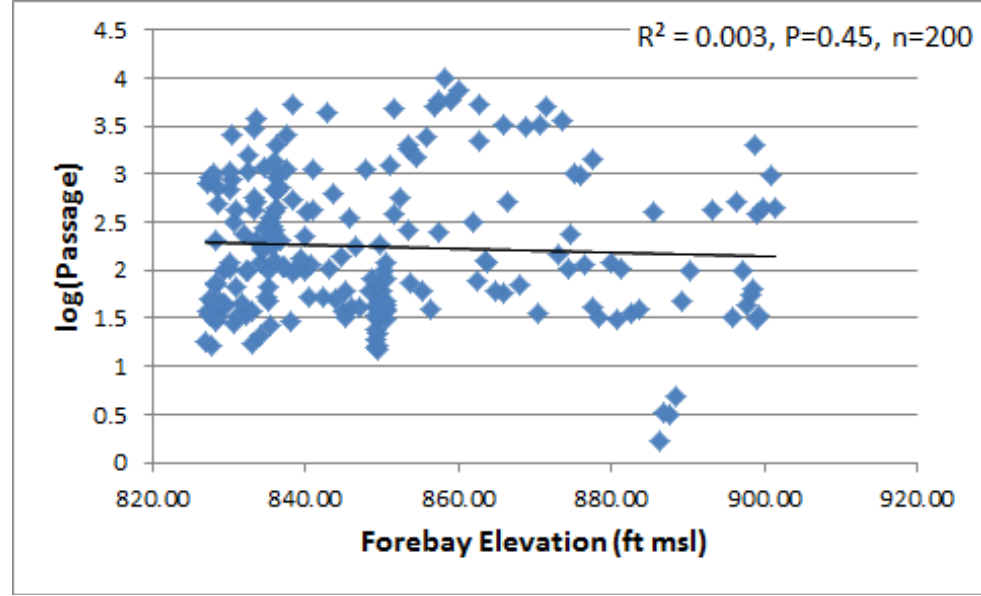

Figure 3.13. Relationship between Passage for Smolt-Size Fish (log10-transformed) and Forebay Elevation (ft above msl)

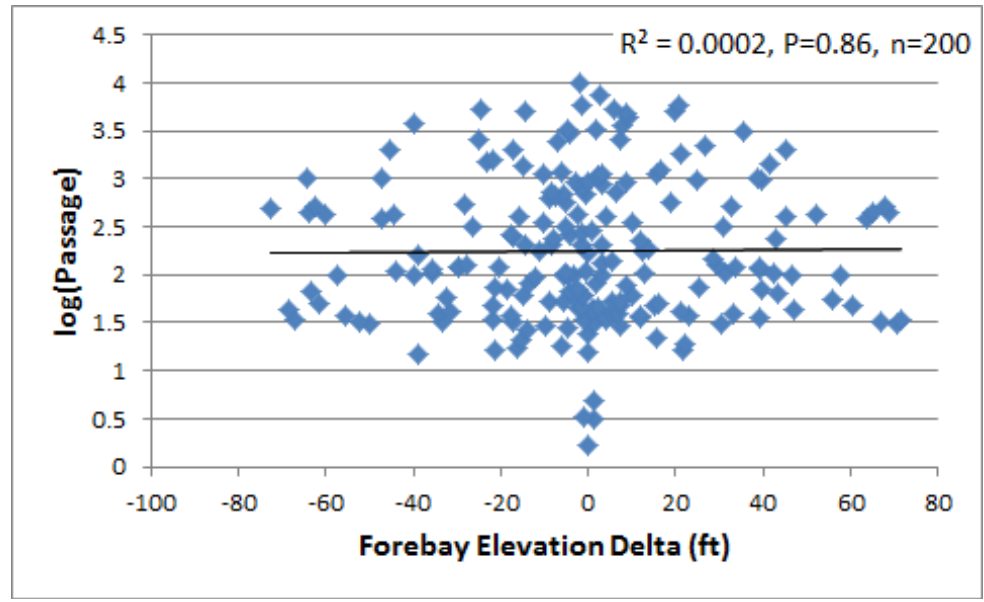

Figure 3.14. Relationship between Passage for Smolt-Size Fish (log10-transformed) and Forebay Elevation Delta (ft; day-to-day change) 


\subsubsection{Multiple Regression and AIC}

The following variables were used in multiple regression models to predict the expected value of daily fish passage:

Table 3.2. Variables Used in the Multiple Regression Models to Predict the Expected Value of Daily Fish Passage

\begin{tabular}{cc}
\hline Number & Variable \\
\hline 1 & Julian Day \\
2 & Log10(Project Discharge) \\
3 & Daily Average Forebay Elevation \\
4 & Log10(Absolute-Value of Forebay Elevation Delta) \\
\hline
\end{tabular}

Model-building results are shown in Table 3.3. There are many models that have AIC scores within 2 of the minimum AIC value, and not all are shown here. The sixth model (Step 6) with AIC 295.8384 was selected because although one of the other models (Step 2) with better AIC scores included all of the original variables that were included in the interaction terms; Step 6 is a good simple model. The coefficients are all significant (Table 3.4). And, each variable causes a statistically significant change to the model if it is omitted from the model (Table 3.5). The model fits the data very well; i.e., the expected values from the model match the observed values very closely with a slope near 1.0 (Figure 3.15; Table 3.5). The model equation is as follows:

$$
\begin{aligned}
\text { Expected value }= & \exp [0.212076+0.001759 * J \text { Day }+0.263515 * \log (\text { Discharge })+ \\
& 0.233753 * \log (\text { abs }(\text { FBay Elevation Delta })]
\end{aligned}
$$


Table 3.3. Multiple Regression Models and AIC Scores. The selected model (Step 6) is highlighted. (DOF is degrees of freedom.)

\begin{tabular}{|c|c|c|c|c|c|c|c|c|c|}
\hline Step & Variable 1 & Variable 2 & Variable 3 & Variable 4 & Variable 5 & DOF & AIC & $\begin{array}{l}\text { Likelihood } \\
\text { Ratio Chi }^{2}\end{array}$ & $\mathbf{p}$ \\
\hline 1 & $\begin{array}{l}\log (\text { ABS(FBay } \\
\text { Elevation Delta) }\end{array}$ & $\begin{array}{l}\text { JDay * Daily } \\
\text { Average FBay } \\
\text { Elevation }\end{array}$ & $\begin{array}{l}\log (\text { Discharge }) * \text { Daily } \\
\text { Average FBay Elevation }\end{array}$ & & & 3 & 295.5880 & 159.3132 & 0.00 \\
\hline 2 & JDay & $\begin{array}{l}\text { Daily Average } \\
\text { FBay Elev (ft) }\end{array}$ & $\begin{array}{l}\log (\text { ABS(FBay Elevation } \\
\text { Delta) }\end{array}$ & $\begin{array}{l}\text { JDay * } \\
\text { log(Discharge) }\end{array}$ & $\begin{array}{l}\text { JDay * Daily } \\
\text { Average FBay } \\
\text { Elevation }\end{array}$ & 5 & 295.5898 & 163.3114 & 0.00 \\
\hline 3 & JDay & $\begin{array}{l}\log (\mathrm{ABS}(\mathrm{FBay} \\
\text { Elevation Delta) }\end{array}$ & $\begin{array}{l}\log (\text { Discharge }) * \text { Daily } \\
\text { Average FBay Elevation }\end{array}$ & & & 3 & 295.6328 & 159.2685 & 0.00 \\
\hline 4 & log(Discharge) & $\begin{array}{l}\log (\mathrm{ABS} \text { (FBay } \\
\text { Elevation Delta) }\end{array}$ & $\begin{array}{l}\text { JDay * Daily Average } \\
\text { FBay Elevation }\end{array}$ & & & 3 & 295.6395 & 159.2617 & 0.00 \\
\hline 5 & JDay & $\begin{array}{l}\text { Daily Average } \\
\text { FBay Elev (ft) }\end{array}$ & JDay * $\log$ (Discharge) & $\begin{array}{l}\text { JDay * Daily } \\
\text { Average FBay } \\
\text { Elevation }\end{array}$ & $\begin{array}{l}\text { Daily Average FBay } \\
\text { Elevation * } \\
\log (\text { ABS(FBay } \\
\text { Elevation Delta) }\end{array}$ & 5 & 295.7223 & 163.1789 & 0.00 \\
\hline 6 & JDay & $\log$ (Discharge) & $\begin{array}{l}\log (\text { ABS(FBay Elevation } \\
\text { Delta) }\end{array}$ & & & 3 & 295.8384 & 159.0628 & 0.00 \\
\hline 7 & $\begin{array}{l}\text { JDay * Daily } \\
\text { Average FBay } \\
\text { Elevation }\end{array}$ & $\begin{array}{l}\text { log(Discharge) }{ }^{*} \\
\text { Daily Average } \\
\text { FBay Elevation }\end{array}$ & $\begin{array}{l}\text { Daily Average FBay } \\
\text { Elevation * log(ABS(FBay } \\
\text { Elevation Delta) }\end{array}$ & & & 3 & 295.8657 & 159.0355 & 0.00 \\
\hline 8 & JDay & $\begin{array}{l}\text { log(Discharge) }{ }^{*} \\
\text { Daily Average } \\
\text { FBay Elevation }\end{array}$ & $\begin{array}{l}\text { Daily Average FBay } \\
\text { Elevation * } \log (\text { ABS(FBay } \\
\text { Elevation Delta) }\end{array}$ & & & 3 & 295.8685 & 159.0327 & 0.00 \\
\hline 9 & log(Discharge) & $\begin{array}{l}\text { JDay * Daily } \\
\text { Average FBay } \\
\text { Elevation }\end{array}$ & $\begin{array}{l}\text { Daily Average FBay } \\
\text { Elevation* } \log (\text { ABS(FBay } \\
\text { Elevation Delta) }\end{array}$ & & & 3 & 295.9012 & 159.0000 & 0.00 \\
\hline 10 & JDay & $\log$ (Discharge) & $\begin{array}{l}\text { Daily Average FBay } \\
\text { Elevation * } \log (\text { ABS(FBay } \\
\text { Elevation Delta) }\end{array}$ & & & 3 & 296.0560 & 158.8452 & 0.00 \\
\hline
\end{tabular}


Table 3.4. Estimated Coefficients for the Selected Model from Set 2, Step 6. Red font indicates significant values.

\begin{tabular}{lcc}
\hline \multicolumn{1}{c}{ Effect } & Estimate & $\mathrm{p}$ \\
\hline Intercept & 0.212076 & 0.002355 \\
Jday & 0.001759 & 0.000000 \\
$\log$ (Discharge) & 0.263515 & 0.000015 \\
$\log$ (ABS(FBay Elevation Delta) & 0.233753 & 0.000000 \\
Scale & 0.496912 & \\
\hline
\end{tabular}

Table 3.5. Results of the Likelihood Type 3 Test for the Selected Model. This test indicates if the model is significantly different without the value on that row (red font).

\begin{tabular}{lcccc}
\hline \multicolumn{1}{c}{ Effect } & $\begin{array}{c}\text { Degrees } \\
\text { of } \\
\text { Freedom }\end{array}$ & $\begin{array}{c}\text { Log- } \\
\text { Likelihood }\end{array}$ & Chi-Square & p \\
\hline Jday & 1 & -176.299 & 64.75922 & 0.000000 \\
Log(Discharge) & 1 & -152.734 & 17.63053 & 0.000027 \\
$\log ($ abs(Fbay Elevation Delta) & 1 & -159.117 & 30.39658 & 0.000000 \\
\hline
\end{tabular}

Table 3.6. Statistics for Goodness of Fit for the Selected Model

\begin{tabular}{cccc}
\hline Statistic & Degrees of Freedom & Value & Value/Degrees of Freedom \\
\hline Pearson Chi ${ }^{2}$ & 196 & 49.384 & 0.251961 \\
Scaled Pearson Chi $^{2}$ & 196 & 200.000 & 1.020408 \\
AIC & & 297.838 & \\
Loglikelihood & & -143.919 & \\
\hline
\end{tabular}


Predicted and Observed Values

Lookout Point

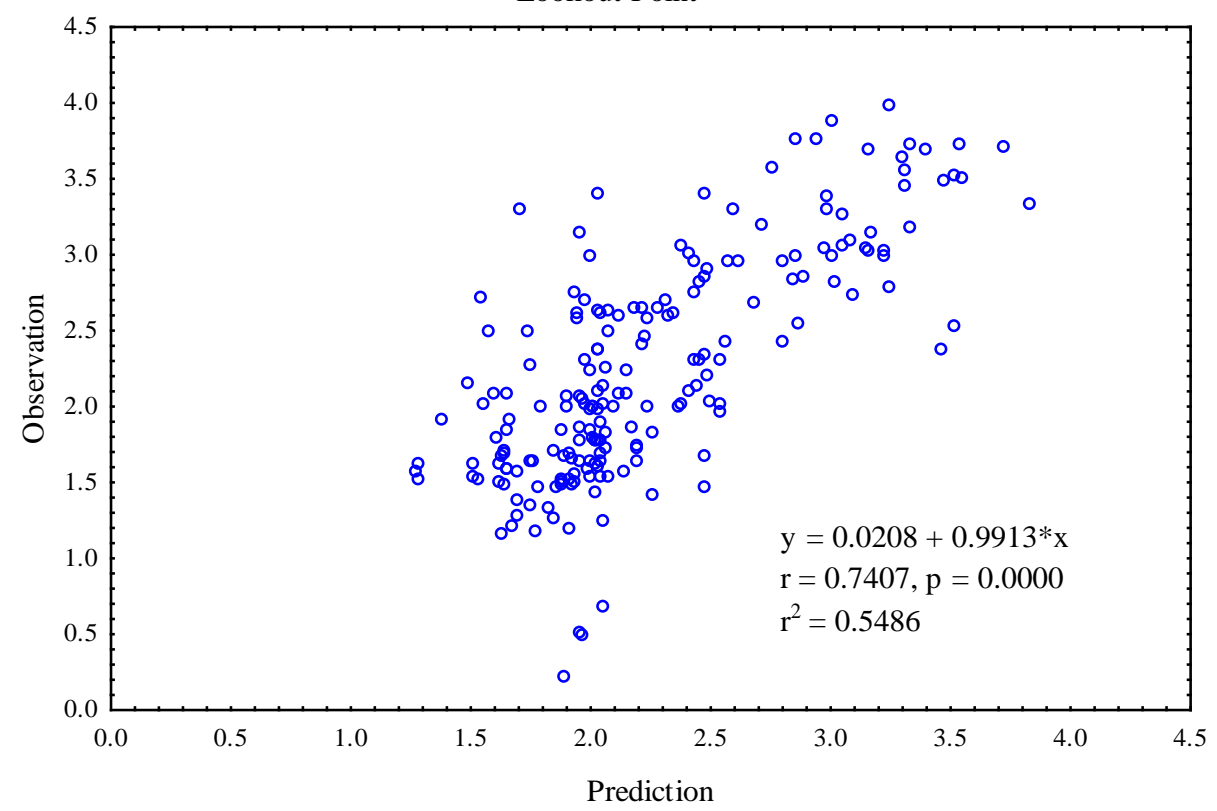

Figure 3.15. Scatterplot of Observed Versus Predicted (=expected) Values for the Selected Model

The multiple regression model indicates a positive trend between expected daily fish passage and each of the three variables in the model—Julian day, $\log ($ discharge), and log(abs(forebay delta)); i.e., as any of the environmental variables increase, expected daily fish passage increases. The forebay elevation variable was not part of the model. The model captures the trend in fish passage well, but some unexplained variation remains. The unexplained variation, however, does not appear to have an obvious structure that would suggest an explanatory factor is missing (Figure 3.16).

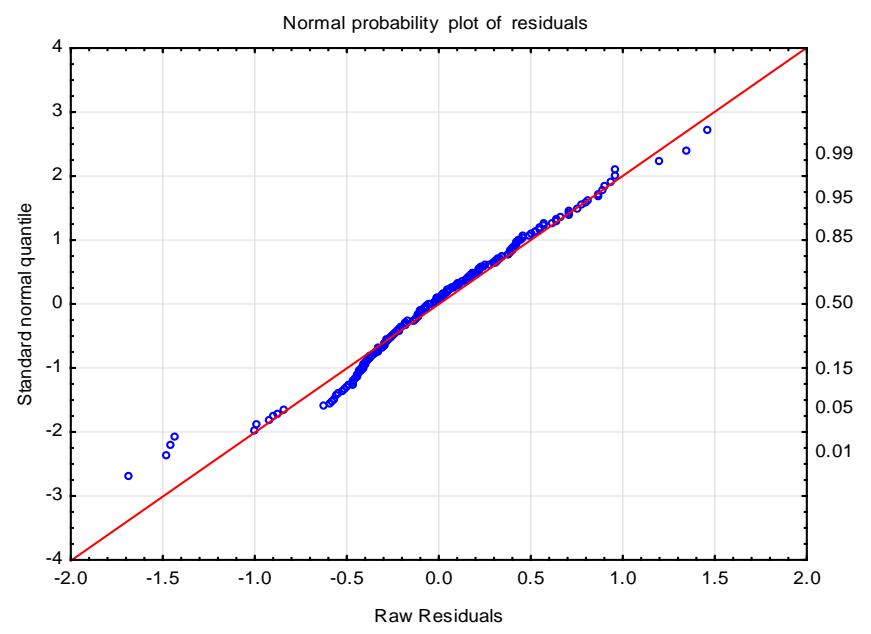

Figure 3.16. Normal Probability Plot of Raw Residuals for the Selected Model 


\subsubsection{Regulating Outlets - Smolt-Size Fish}

We estimated that 13 smolt-size fish ( \pm 8 fish, 95\% CI) passed via the ROs when they were open from June 8 through June 14, 2010. During the December-January period when the ROs were open, RO passage peaked at 93 fish on December 15, 2010 (Figure 3.17). Generally, RO passage for smolt-size fish was low or zero on most days of the Winter period. An estimated 212 smolt-size fish ( \pm 63 fish, 95\% CI) passed into the ROs during the December-January period. When the ROs were open, RO efficiency (RO passage divided by total project passage) was 0.004 .

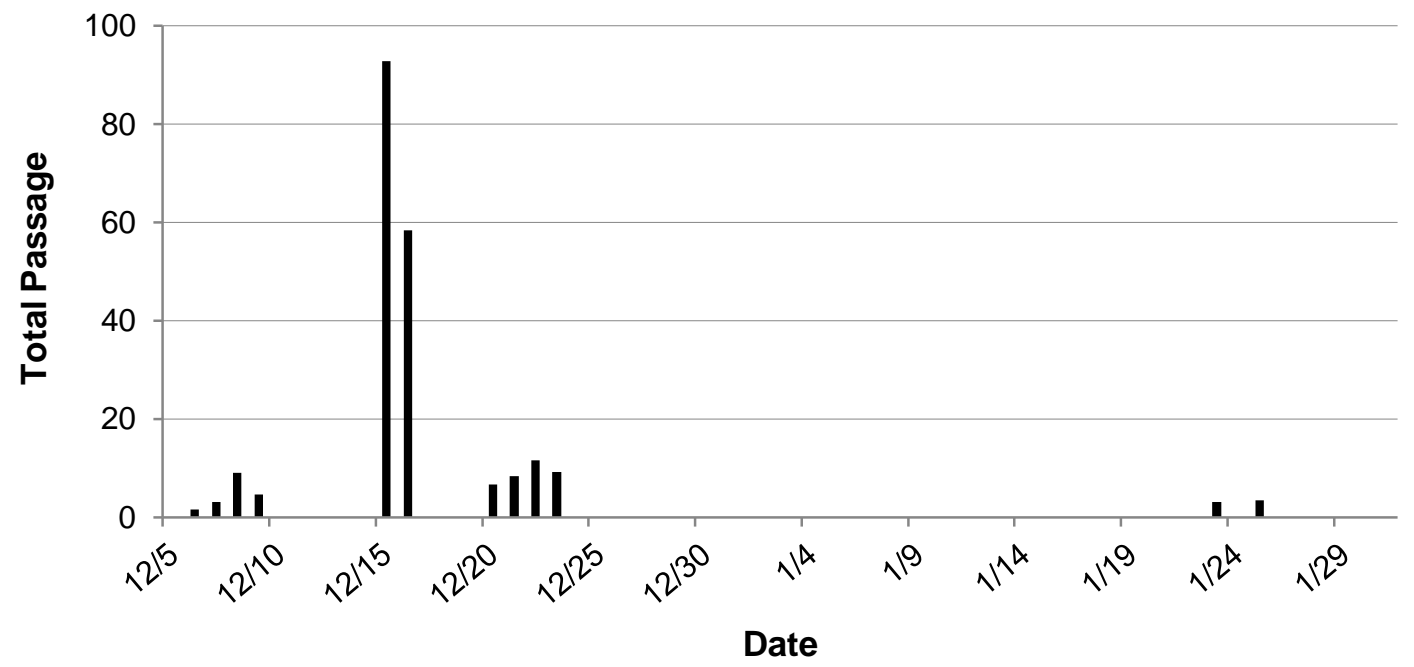

Figure 3.17. Estimated Daily Passage of Smolt-Size Fish at LOP Regulating Outlets from December 5, 2010, through January 31, 2011. See Figure 3.2 for RO discharge.

\subsubsection{Vertical Distribution}

Full water column sampling of vertical distribution at the dam face (Figure 2.1) showed that fish distribution was deepest during the Refill and Full Pool periods (62\% above $10 \mathrm{~m}$ ) and shallowest during the Flat Elevation and Fall Release periods (80\% above $10 \mathrm{~m}$ ) (Figure 3.18). Temperature data for the water column in the forebay of LOP were only available for the Flat, Fall Release, and Fall Rains periods (Figure 3.19). During these periods, water temperature in the surface $5 \mathrm{~m}$ ranged from $19.5^{\circ} \mathrm{C}$ in August to $12.1^{\circ} \mathrm{C}$ in November and was much cooler at depth, ranging from $11.7^{\circ} \mathrm{C}$ in August to $10.6^{\circ} \mathrm{C}$ in November, for the 30- to 35-m depth bin (Figure 3.19). Fish were distributed in the upper $20 \mathrm{~m}$ of forebay over the course of the study (Figure 3.19). During six of seven dam operations periods, the 5-10m-depth bin had the highest percentage of fish (30\%-60\%). 


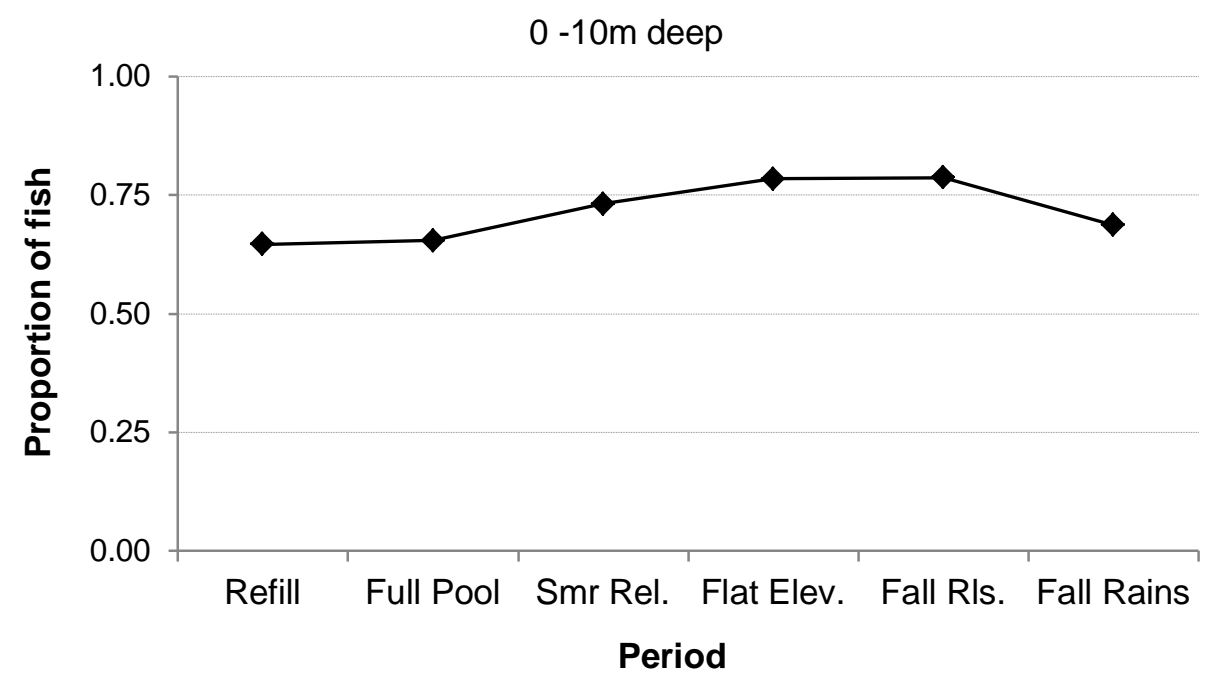

Figure 3.18. Vertical Distribution of Fish (total of both Small-Size and Smolt-Size) at the Forebay Dam Face Expressed as the Proportion of Fish in the Surface $10 \mathrm{~m}$ by Dam Operations Period 
a) Refill (March 1 - May 8)

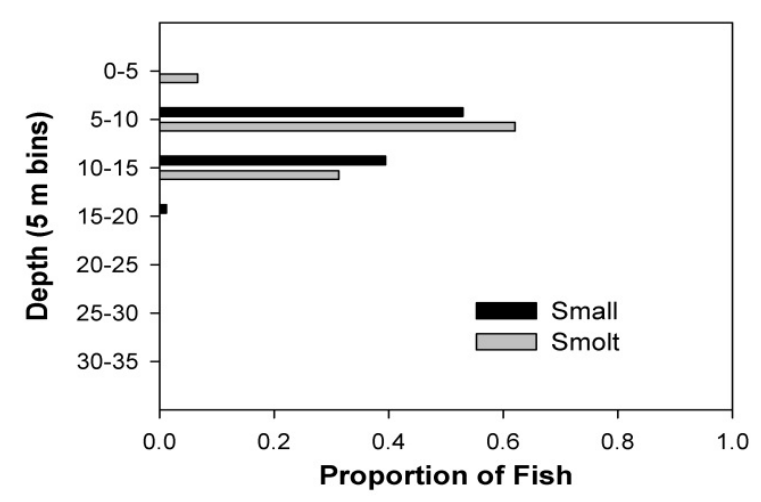

c) Summer Release (June 7- July 31)

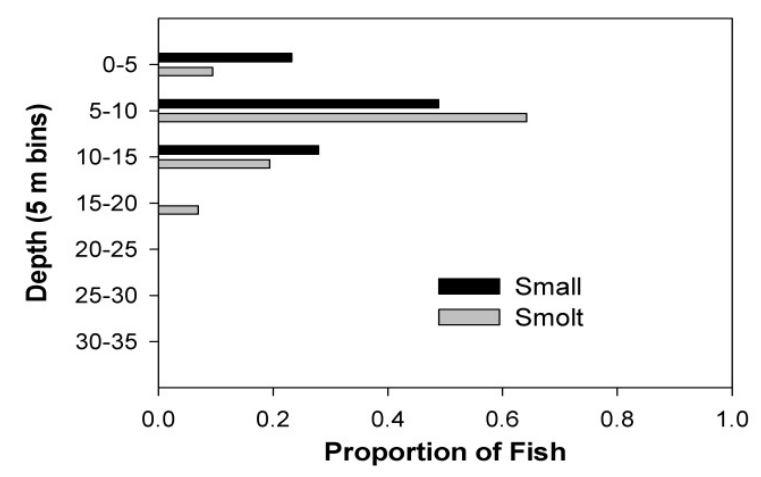

e) Fall Release (September 4 - October 23)

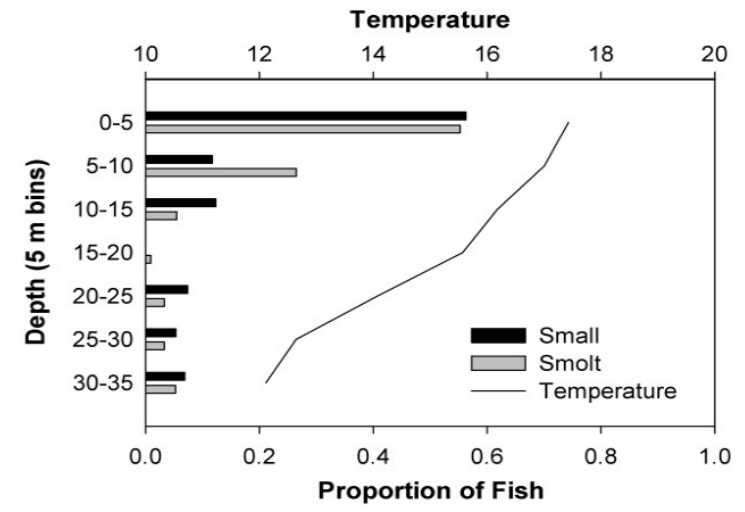

b) Full Pool (May 9 - June 6)

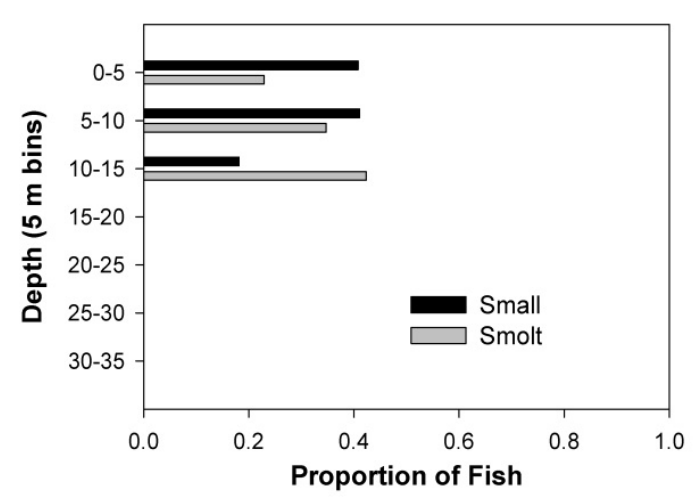

d) Flat Elevation (August 1 - September 4)

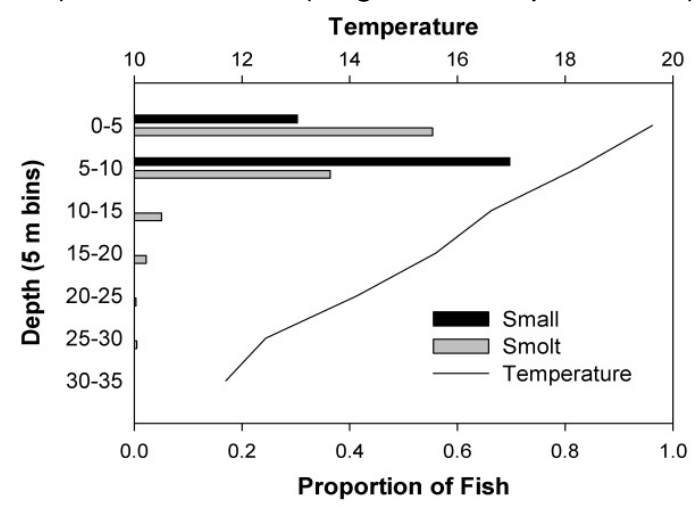

f) Fall Rains (October 24 - November 30)

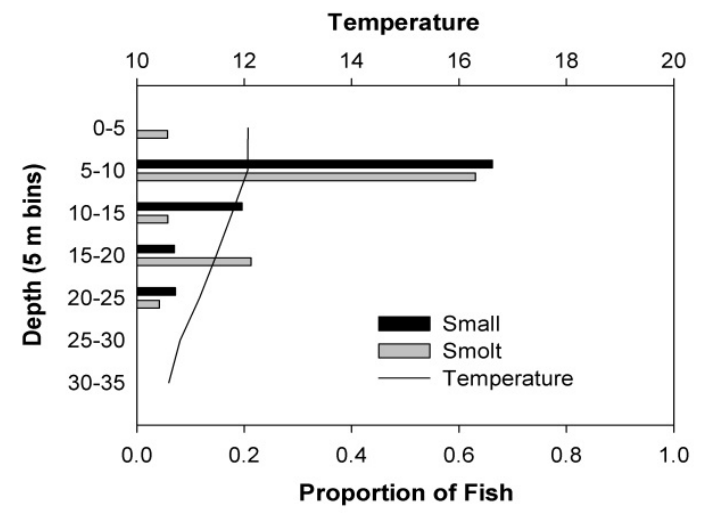

Figure 3.19. Vertical Distribution of Small-Size (black) and Smolt-Size (gray) Fish and Water Temperature $\left({ }^{\circ} \mathrm{C}\right)$ at the Forebay Dam Face Separately by Dam Operations Period. Notes: 1) water temperature data were only available for August through November, and 2) data for the Winter period (December 1 - January 31) were not collected because we stopped collecting these data at the end of November when the pool was at the same elevation as the transducers and dropping, meaning the transducers were out of water during winter. Water temperature data were obtained from the USACE Portland Office. 
The forebay abundance index derived from the vertical distribution data set peaked in summer for both smolt-size and small-size fish (Figure 3.20). A smaller peak in the forebay abundance index occurred in spring 2010. The forebay abundance index indicates the availability of fish to possibly pass the dam.

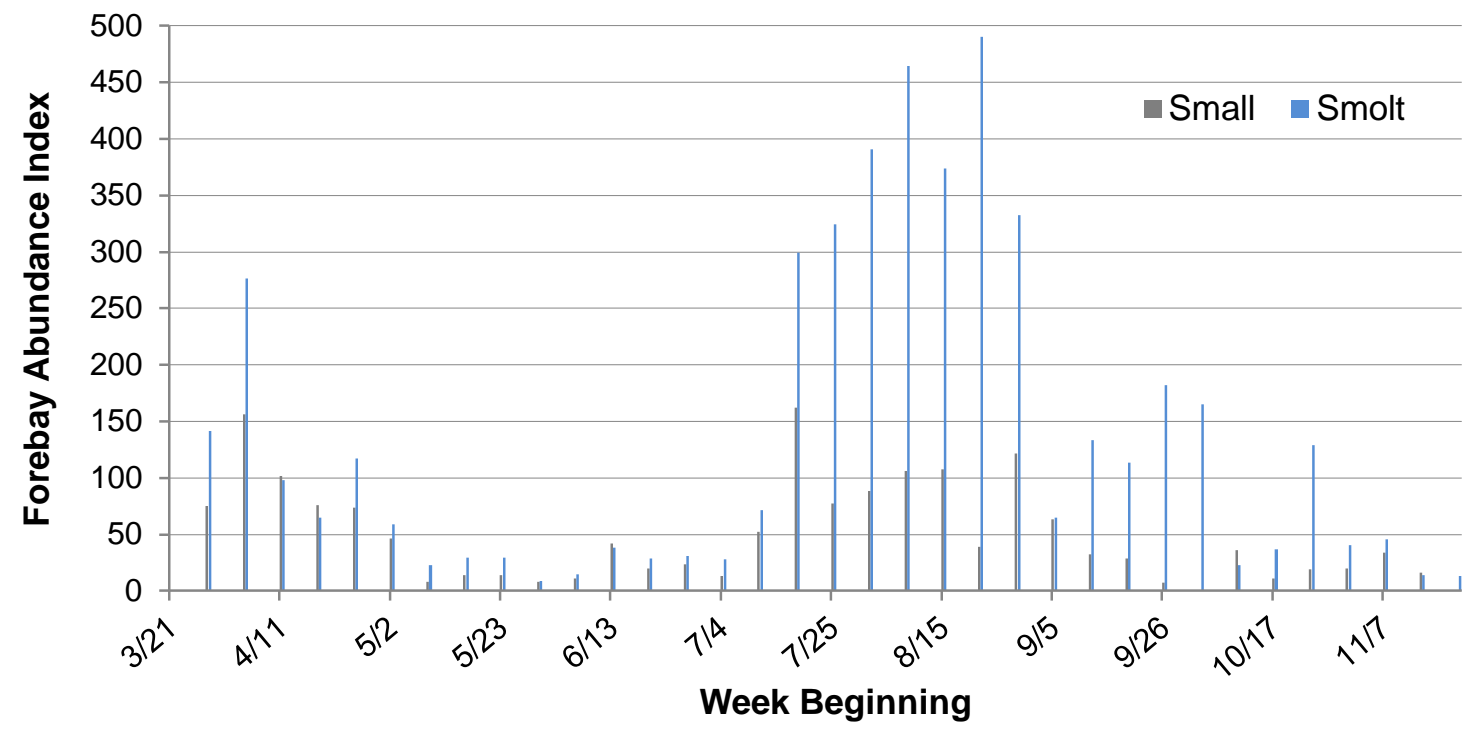

Figure 3.20. Forebay Abundance Index. These data are weekly estimates of total fish estimates from the forebay vertical distribution transducers. Fish detections were extrapolated to an arbitrary width of $5 \mathrm{~m}$ for the purpose of the abundance index. The vertical distribution transducers were removed in late November because of low forebay elevation.

\subsubsection{Acoustic Size (Target Strength)}

During spring and summer, mean target strengths ${ }^{1}$ for the analysis periods ranged from -44.2 to -42.1 $\mathrm{dB}$ (Table 3.7). These values are indicative of yearling-sized juvenile salmon. In contrast, mean target strengths in fall and winter were about $-49.0 \mathrm{~dB}$, which is representative of subyearling-sized fish. The frequency distribution of target strengths was typically unimodal (Figure 3.21).

Table 3.7. Target Strengths (dB re: 1uPa @ 1 m) by Analysis Period

\begin{tabular}{lcccccc}
\hline Analysis Period & Dam Operations Period & $\mathrm{n}$ & mean & s.d. & s.e. & median \\
\hline April 2-14 & Refill & 37 & -44.2 & 4.0 & 0.7 & -44.4 \\
June 4-9 & Full Pool & 94 & -42.1 & 2.3 & 0.2 & -47.7 \\
June 18-28 & Summer Release & 117 & -42.9 & 2.8 & 0.3 & -42.7 \\
July 21-22 & Summer Release & 26 & -42.2 & 1.9 & 0.4 & -42.4 \\
Oct 27-29 & Fall Release & 257 & -49.3 & 2.5 & 0.2 & -49.6 \\
Nov-22 Jan 4 & Fall Rains/Winter & 6844 & -49.0 & 2.5 & 0.03 & -49.2 \\
Jan 5-31 & Winter & 1873 & -49.0 & 3.2 & 0.1 & -49.6 \\
\hline
\end{tabular}

\footnotetext{
${ }^{1}$ Mean target strength for individual fish was measured using a split-beam hydroacoustic system (MacLennan and Simmonds 1992).
} 


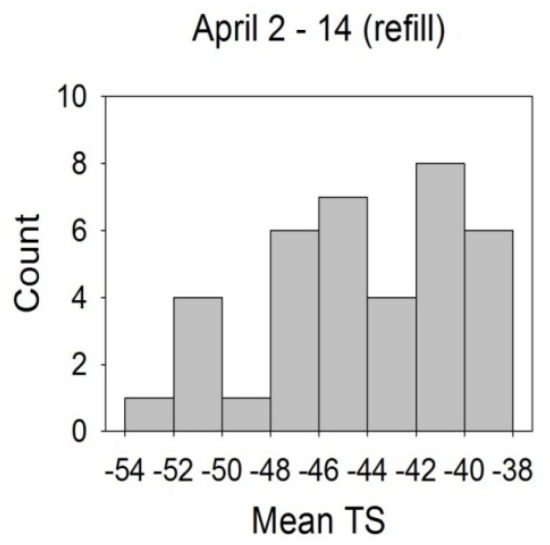

June 18 - 28 (sumr release)

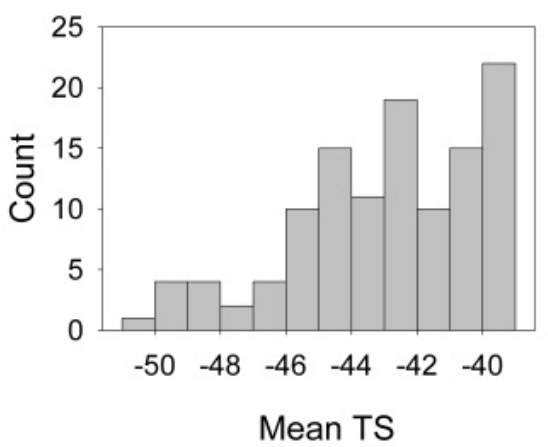

October 27 - 29 (fall release)
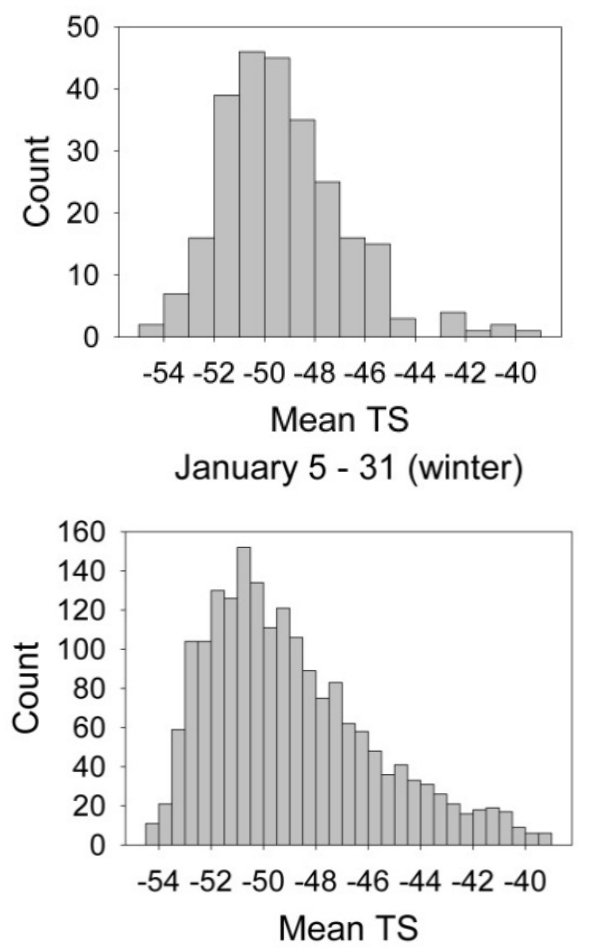

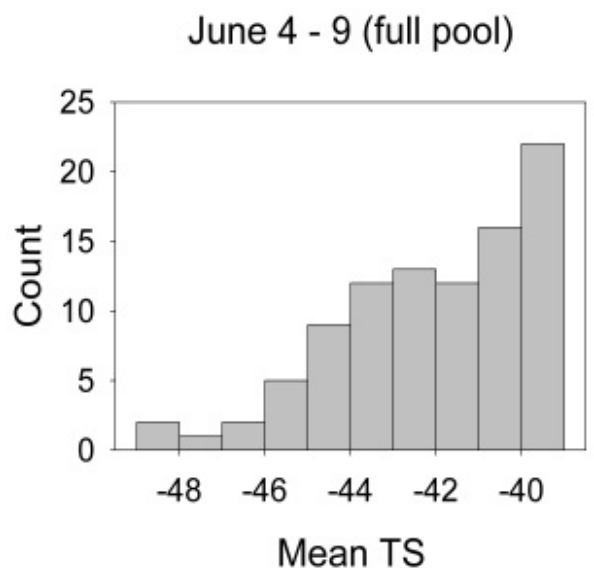

July 21 - 22 (smr release)

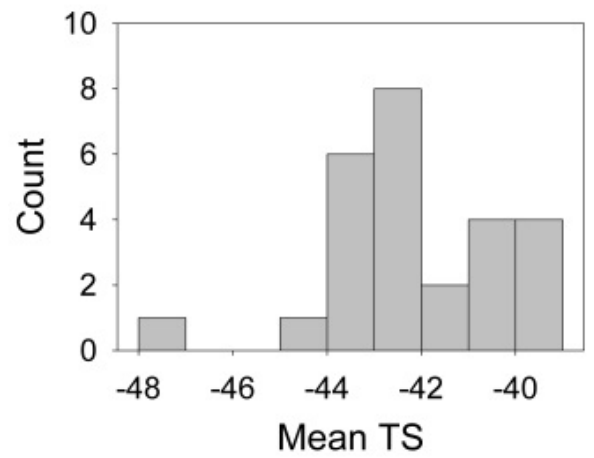

Nov 22 - Jan 04 (fall rains - winter)

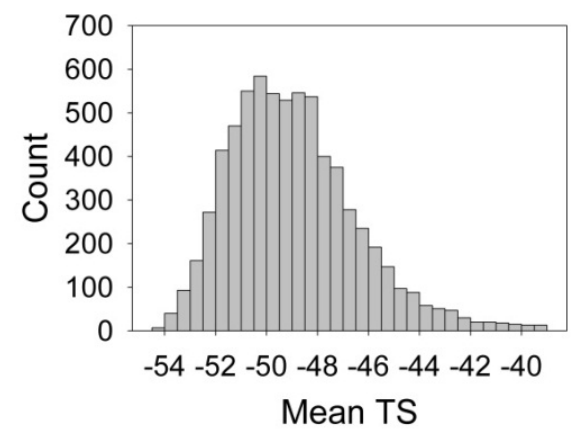

Figure 3.21. Frequency Distribution of Mean Target Strength for Individual Fish by Analysis Period 



\subsection{Discussion and Recommendations}

The results of the hydroacoustic study of juvenile salmonid passage and distribution at Lookout Point Dam on the Middle Fork Willamette River provide new and, in some cases, first-ever data about passage estimates, run timing, relationships between passage and environmental variables, and horizontal, diel, and vertical distributions of fish at the dam. Findings from this 1 year of study should be applied carefully because annual variation can be expected due to variability in adult salmon escapement, egg-tofry and fry-to-smolt survival rates, reservoir rearing and predation, dam operations, weather, etc.

\subsection{Data Reliability}

The non-obtrusive hydroacoustic data from this study are reliable because passage patterns were similar to those observed in the direct-capture data from the tailrace screw trap. Based on trap data, juvenile Chinook salmon of several size classes moved through the dam at times in June, late July through mid-August ( 150 mm), and December-January (bimodal distribution 110 mm and 150 mm) (Keefer et al. 2011). The timing of these passage peaks was similar to what we observed (Figure 3.4, Figure 3.5, and Figure 3.8). Also, it is noteworthy that the hydroacoustic and direct-capture results were consistent in indicating passage had a bi-modal size distribution during the large surge of fish in winter. Independent estimates of juvenile Chinook salmon run size for 2010 were comparable between hydroacoustic data ( 144,000 fish $\pm \sim 37,000)$ and screw-trap data (7,000-83,000 fish), depending on assumptions in the estimator (Keefer et al. 2011). These findings are reasonable considering that the hydroacoustic numbers are overestimates because of non-salmonid targets and the trap numbers are underestimates because of low detection rates for dead fish (Keefer e al. 2011).

Data reliability is also shown by the consistency of diel and vertical distribution patterns when compared with other studies of juvenile salmonid passage at dams. The crepuscular periodicity of diel passage into the turbine penstock intakes we documented (Figure 3.7 and Figure 3.9) is common for juvenile salmonids, especially Chinook salmon, at main-stem Columbia and Snake river dams (Thorne and Johnson 1993; Ferguson et al. 2005). This indicates the hydroacoustic detections were predominantly fish because sticks and leaves would not have crepuscular patterns. The surface-oriented vertical distribution of fish we found (Figure 3.13 and Figure 3.14) is a prevalent behavior for juvenile salmonids (e.g., Johnson and Dauble 2006; Ploskey et al. 2007a; Smith et al. 2009). While fish behavior certainly is important, dam operations that determine forebay elevations and project discharge rates also play a role in influencing passage and distribution patterns at hydropower dams (Ploskey et al. 2007a).

\subsection{Passage and Environmental Factors}

Fish passage at LOP was related to dam and reservoir operations and, possibly, biological factors as well. The dawn crepuscular passage pattern typically followed the morning increase in project discharge, providing a possible queuing mechanism for emigration (Figure 3.7). Diel passage and project discharge were highly correlated during the Refill (March 1-May 8) and Winter (December 1-January 31) periods (Figure 3.7), indicating an operational influence. However, diel passage peaks during the other periods (Full Pool, Fall Release, and November Rains) were not correlated with project discharge, indicating a biological influence to passage. The relationship between daily fish passage and project discharge, however, was significant $(P<0.001)$, although discharge explained only $20 \%$ of the fish passage 
variability (Figure 3.12). The influence of dam and reservoir operations on fish passage is indicated by the finding that variables for project discharge and absolute-value of forebay elevation delta were positively related to expected fish passage in the selected multiple regression model (Section 3.2.3.2). Project operations and salmon biology certainly affect downstream passage. Operational and biological factors influencing fish passage, however, are confounded in an observational field study such as ours, making it difficult to discern between juvenile salmon movement and migration downstream.

The run-timing data for fish passage at LOP indicate both operational and biological influences. Runtiming peaks occurred during the Refill, Full Pool, and Winter periods (Figure 3.4). The noticeable passage peak in early spring during refill indicates a biological response. We did not observe run-timing peaks when the reservoir elevation was being lowered during late summer and early fall (Figure 3.4), except for a peak in small-size fish in mid-August that was likely crappie (Figure 3.6; Keefer et al. 2011). We observed the highest passage rates during the Winter period when forebay elevation was quite variable (Figure 3.1, Figure 3.4, and Figure 3.5). This is consistent with the absolute value of forebay elevation delta being an important variable in the selected multiple regression model (Table 3.3, Table 3.4, and Table 3.5). Julian day was an important variable in the multiple regression model because highest passage rates were observed in winter when Julian day values are largest.

Fish-trapping rates in the tailrace screw traps were negatively correlated with forebay elevation as reported by Keefer et al. (2011), but we did not find such a relationship. These authors attributed high passage rates in winter, in part, to low reservoir elevations increasing fish access to otherwise deep turbine penstock intakes and ROs. Juvenile salmonids are generally reluctant to sound to pass dams, but when surface outlets are not available, they will sound to pass obstructions through a relatively deep outlet (Andrew and Geen 1960; Johnson 1996). Undoubtedly, though, juvenile salmonids prefer surface flows rather than deep flows to pass hydropower dams (Johnson 1996; Johnson and Dauble 2006). While Keefer et al. (2011) postulate that low forebay elevations are conducive to juvenile salmonid passage at LOP, they note that juvenile salmonid emigration timing is complex and many factors are involved.

Keefer et al. (2011) hypothesized that spring refill could inhibit emigration of yearling salmon through the dam because project discharge can be curtailed to fill the reservoir. We noted a relatively small passage peak in early April for both small-size and smolt-size fish during the spring Refill period (Figure 3.1, Figure 3.4, and Figure 3.6). Interestingly, the late spring surge in passage (Figure 3.4) occurred when the reservoir was full (Figure 3.1) and project discharge was increasing (Figure 3.2). This pattern supports the influence of project discharge on passage, but also indicates juvenile salmonids will sound to pass LOP through the turbine penstock intakes if penstocks are the only route available. Factors influencing fish passage are a complex, varying combination of operational and biological variables.

Dam operations at LOP during 2010 involved RO discharge of excess water beyond turbine discharge capacity for 13 days in early summer and 49 days in winter; spill bays at LOP were not operated in 2010. $\mathrm{RO}$ fish passage rates were low (2 fish/d in early summer and 8 fish/d in winter). RO efficiency relative to total project passage was 0.004 . These data support the need for more surface-oriented passage collection or passage routes, such as spill bays, at least for research and development purposes. The ROs are not a viable long-term, non-turbine fish passage route because they are deep outlets, approximately $56 \mathrm{ft}$ below the ceiling of the turbine penstock intakes. Managers should consider a fish passage test of surface spill, noting that unsafe outfall conditions must be weighed into any decision. A quick, focused test to demonstrate whether juvenile salmonids will pass could be appropriate at a time of year when emigrants are expected. A treatment test is not necessary to simply confirm that surface flow would pass or could be used to collect fish at LOP. 


\subsection{Implications for Collector Design}

Vertical distribution data are fundamental to designing structures for downstream fish passage or collection (Giorgi and Stevenson 1995; ENSR/AECOM 2007). Distribution data are also used to aid in the design of project operations intended to increase fish passage survival. Extending forebay vertical distribution patterns from the dam face to the reservoir is permissible because juvenile salmonids generally tend to be distributed in surface waters (Johnson 1996; Smith et al. 2009). There are exceptions to this pattern when reservoir water temperatures are high in surface water and fish move to deeper, cooler water, as Monzyk et al. (2011b) observed in the LOP reservoir during 2010. Bioengineers will need to consider this behavior for in-reservoir design alternatives to collect juvenile salmon; such designs are currently being contemplated (AECOM and BioAnalysts 2010). Design of passage structures should incorporate debris load and its effect on fish passage at any new passage or collection structures, especially during winter months when high numbers of juvenile salmonids pass the dam (Figure 3.4; Keefer et al. 2011). Daily passage numbers of tens to thousands of juvenile salmonids (Figure 3.4) may be expected to enter collectors or passage devices. Collector design must also support multiple life histories of fish emigrating at various times of the year. In fact, in-tributary collectors may affect these expressions. If a life-history pattern is to emigrate from streams and rear in downstream locations, such as slow-moving areas like reservoirs, then collection could disrupt this.

\subsection{Life-History Strategies}

Multiple Chinook salmon life-history strategies in a given watershed are not uncommon (Healey 1991; Quinn 2005). In addition to the typical yearling and subyearling emigrations to saltwater, there can be many variations on these themes. For example, Marsh et al. (2009) concluded from passive integrated transponder (PIT)-tag data and scale analyses that juvenile salmon were overwintering in mainstem reservoirs of the Snake River. Connor et al. (2005) described an alternative life history for juvenile Snake River fall Chinook salmon they named "reservoir-type” life history. Fish having this life history delay their migration as subyearlings to spend winter in freshwater, and resume emigration to the ocean the following year to enter the ocean as yearlings. Because Chinook salmon display a wide range of lifehistory strategies (Healey 1991), juvenile salmon arrival and rearing in the LOP reservoir potentially could occur year-round with subsequent emigration possible over multiple time periods (Figure 4.1).

Willamette spring Chinook salmon can express several life-history strategies (Keefer and Caudill 2010). Along with the typical yearling outmigration in spring, there can be subyearling migration to downstream rearing areas in fall and winter. Another variation is subyearling migration from natal streams to rear in reservoirs before outmigrating as yearlings. Spring Chinook salmon from the LOP watershed may exhibit some or all of these life-history strategies. Keefer et al. (2011) concluded that LOP screw-trap data revealed at least two early life-history patterns, and perhaps as many as four for juvenile Chinook salmon emigrations through LOP. Based on snorkel surveys and trapping, Monzyk et al. (2011a) observed Chinook salmon fry, subyearlings, and yearlings in the LOP reservoir during 2010. In addition, they detected PIT-tagged subyearling and yearling Chinook salmon from LOP in winter at a detection site at the Sullivan Plant on the Willamette River near Portland, Oregon (Monzyk et al. 2011a), thereby confirming these two emigration patterns.

Multiple life-history strategies in the LOP watershed are also suggested by the run-timing and target strength data from our study and concurrent fish-length data from direct capture research. These data indicate there may be at least four life-history patterns at LOP (Figure 4.1): spring yearlings, early summer yearlings, late fall/winter subyearlings, and late fall/winter yearlings. The inferences from run- 
timing patterns to life-history diversity, however, must be made cautiously because daily fish passage was related to project discharge and other factors (Figure 3.12). The mechanisms for downstream juvenile salmonid passage include fish physiology providing motivation and project discharge providing the means. Most importantly, the run-timing peaks we observed are consistent with possible emigration patterns described by Keefer and Caudill (2010), Keefer et al. (2011) and Monzyk et al. (2011a).

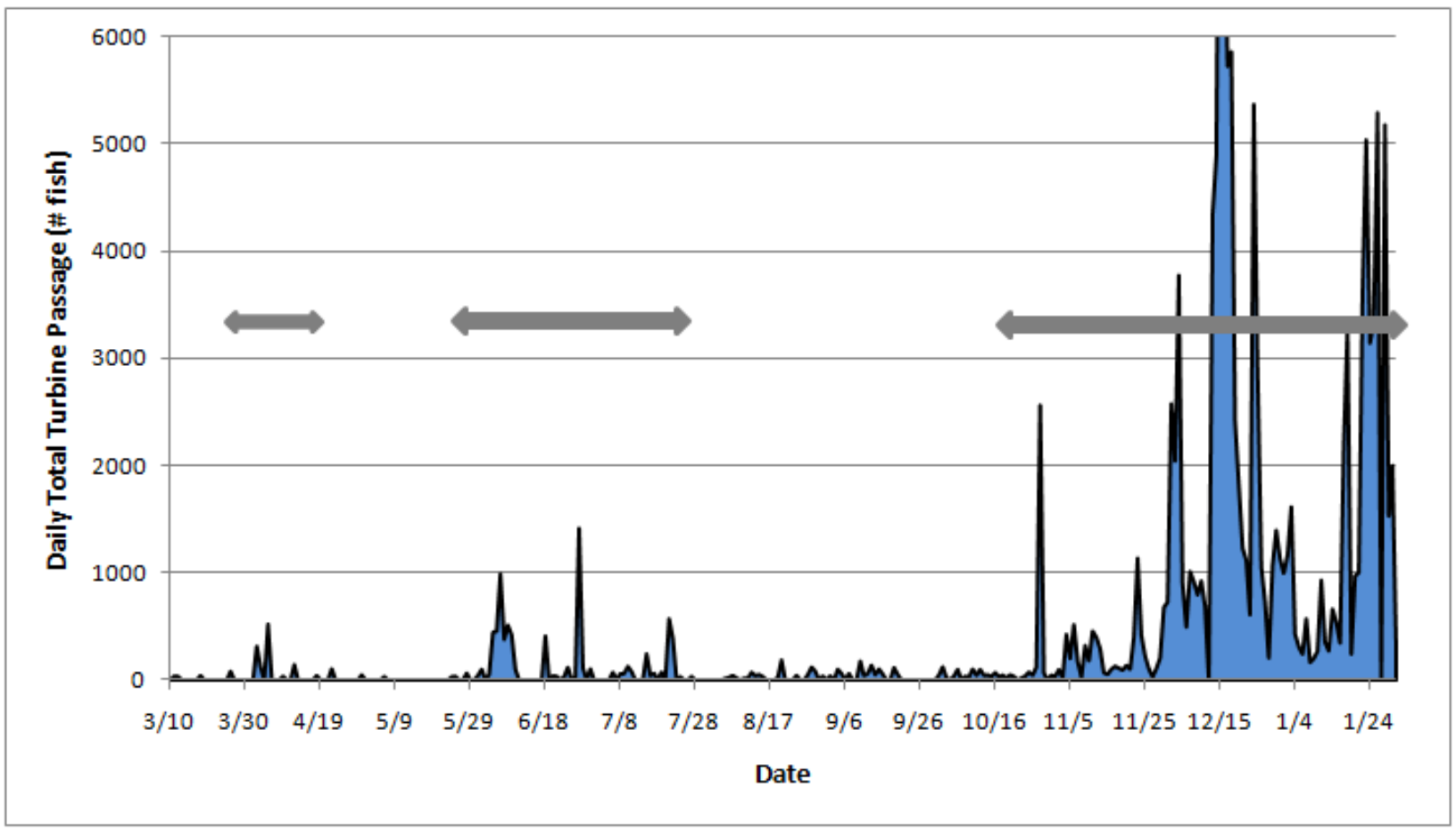

Figure 4.1. Run Timing for Smolt-Size Fish Depicting Possible Life-History Strategies at LOP from March 2010 through January 2011. There were two size classes of fish in winter (Keefer et al. 2011).

The ramifications of life-history diversity to Chinook salmon recovery efforts at LOP are promising because, even without any passage or collection improvements at LOP, multiple early life-history patterns are already apparent. This means the recovery effort is not starting from scratch in terms of life-history diversity. As noted above, it will be important to design passage or collection solutions that maintain and enhance this life-history diversity. Enhanced life-history diversity should provide increased resiliency to environmental perturbations (Waples et al. 2009). With suppressed life-history diversity for salmon being a general concern (Bottom et al. 2005), one of the objectives of the ecosystem restoration is to increase life-history diversity through habitat quality improvements and the use of fish passage or collection systems (NMFS 2008). Reduced habitat diversity can lead to decreased life-history diversity (Beechie et al. 2005). Dispersion of juvenile salmon in various routes and times during rearing and downstream migration could buttress resiliency by decreasing the overall probabilities of encountering poor water quality, predators, or other deleterious conditions (Koski 2009). Restoring sustainable ecological processes and removing barriers to movement that support multiple life-history strategies over the long term is key to recovery of listed salmon and steelhead species (Waples et al. 2009; Williams 2006). 


\subsection{Summary and Conclusions}

The findings from the hydroacoustic evaluation of juvenile salmonid passage and distribution at LOP from February 2010 through January 2011 are summarized as follows:

- Fish passage rates for smolt-size fish $\left(>\sim 90 \mathrm{~mm}^{1}\right.$ and $\left.<300 \mathrm{~mm}\right)$ were highest during DecemberJanuary and lowest in mid-summer through early fall. Passage peaks were also evident in early spring, early summer, and late fall.

- During the entire study period, an estimated total of 142,463 fish \pm 4,444 (95\% CI) smolt-size fish passed through turbine penstock intakes. Not counting December-January months, the estimated total passage at LOP (March ${ }^{2}$-November) was 22,442 fish \pm 3,095.

- Diel periodicity of smolt-size fish showing crepuscular peaks was evident in fish passage into turbine penstock intakes.

- Run timing for small-size fish ( 65-90 mm) peaked (702 fish) on December 18. Downstream passage of small-size juvenile fish was variable (see the CI for the total passage estimate below), occurring on 2 days in the spring (March 11 and April 4), 8 days in the summer, and at times throughout late fall and winter. A total of 7,017 \pm 690 small-size fish passed through the turbine penstock intakes during the study period.

- In linear regression analyses, daily fish passage (turbines and ROs combined) for smolt-size fish was significantly related to project discharge $(P<0.001)$. This relationship was positive, but there was no relationship between total project passage and forebay elevation $(P=0.48)$ or forebay elevation delta, i.e., day-to-day change in forebay elevation $(P=0.16)$.

- In multiple regression analyses, a relatively parsimonious model was selected that predicted the observed data well. The multiple regression model indicates a positive trend between expected daily fish passage and each of the three variables in the model—Julian day, $\log$ (discharge), and $\log (a b s(f o r e b a y ~ d e l t a)) ;$ i.e., as any of the independent variables increase, expected daily fish passage increases.

- Relatively few fish passed into the regulating outlets when they were open in summer (2 fish/d) and winter (8 fish/d). Overall, when the ROs were open, RO efficiency (RO passage divided by total project passage) was 0.004 .

- Fish were surface-oriented with $62 \%-80 \%$ above $10 \mathrm{~m}$ deep. The highest percentage of fish (30\%$60 \%$ ) was in the 5-10-m-depth bin.

- During spring and summer, mean target strengths for the analysis periods ranged from -44.2 to -42.1 $\mathrm{dB}$. These values are indicative of yearling-sized juvenile salmon. In contrast, mean target strengths in fall and winter were about $-49.0 \mathrm{~dB}$, which are representative of subyearling-sized fish.

We draw the following conclusions from the study:

- The non-obtrusive hydroacoustic data from this study are reliable because passage estimates and patterns were similar to those observed in the direct-capture data from the tailrace screw trap and were consistent with distribution patterns observed in other studies of juvenile salmonid passage at dams.

\footnotetext{
${ }^{1}$ Fish length is an approximation from measured target strength based on Love (1977).

${ }^{2}$ February 2010 is not included because this is when transducer deployment and optimization occurred.
} 
- Hydroacoustically estimated run timing coupled with fish size data from screw traps indicate four life-history strategies may have been expressed by Chinook salmon at LOP: early spring yearlings, early summer yearlings, late fall/winter yearlings, and late fall/winter subyearlings.

- Operational and biological factors influencing fish passage, however, are confounded in an observational field study such as ours, making it difficult to discern between juvenile salmon movement and migration downstream. Factors influencing fish passage are a complex, varying combination of operational and biological variables.

- The surface-oriented vertical distribution of fish we observed supports development of surface passage or collector devices.

- Collector design should support multiple life histories of fish emigrating at various times of the year.

\subsection{Recommendations}

We offer the following recommendations for future research at LOP to support the design of fish passage or collection systems:

- Consider conducting a quick, focused test of surface spill to demonstrate whether juvenile salmonids will pass at a time of year when emigrants are expected.

- Consider conducting mobile hydroacoustic surveys coupled with direct observations to provide estimates of juvenile salmonid distribution and abundance by fish size class in LOP reservoir (e.g., Faber et al. 2005).

- Consider applying acoustic imaging techniques, such as head-of-reservoir or in-reservoir sampling devices or prototype surface collectors, to quantify fish behavior at key locations (e.g., Johnson et al. 2009a, b).

In closing, the spatially and temporally high-resolution data reported herein provide detailed estimates of vertical, horizontal, diel, daily, and seasonal passage and distributions and analyses of relationships between fish passage and environmental variables at LOP from March 2010 through January 2011. This

information is applicable to management decisions on the design and development of surface passage and collection devices to help restore Chinook salmon populations in the Middle Fork Willamette River watershed above Lookout Point Dam. 


\subsection{Literature Cited}

AECOM and BioAnalysts. 2010. Willamette Downstream Fish Passage Design Requirements Report. Final report for Contract W9127N-10-D-0002, T.O. 003 submitted to the U.S. Army Corps of Engineers, Portland District, Portland, Oregon.

Anderson DR, KP Burnham, and GC White. 1994. “AIC Model Selection in Overdispersed CaptureRecapture Data.” Ecology 75:1780-1793.

Andrew FJ and GH Geen. 1960. "Sockeye and Pink Salmon Production in Relation to Proposed Dams in the Fraser River System.” International Pacific Salmon Fisheries Commission Bulletin, XI, New Westminster, British Columbia, Canada.

Brambor T, WR Clark, and M Golder. 2006. “Understanding Interaction Models: Improving Empirical Analyses.” Political Analysis 14:63 82.

Beechie TJ, M Liermann, EM Beamer, and R Henderson. 2005. “A Classification of Habitat Types in a Large River and Their Use by Juvenile Salmonids.” Transactions of the American Fisheries Society 134:717-729.

Bottom DL, CA Simenstad, J Burke, AM Baptista, DA Jay, KK Jones, E Casillas, and M Schiewe. 2005. "Salmon at River's End: The Role of the Estuary in the Decline and Recovery of Columbia River Salmon.” Technical Memorandum NMFS-NWFSC-68, U.S. Department of Commerce, National Oceanic and Atmospheric Administration, Northwest Fisheries Science Center, Seattle, Washington.

Carlson TJ, WC Acker, and DM Gaudet. 1981. Hydroacoustic Assessment of Downstream Migrant Salmon and Steelhead at Priest Rapids Dam in 1980. APL-UW 8016, Applied Physics Laboratory, University of Washington, Seattle, Washington.

Connor WP, JG Sneva, KF Tiffan, RK Steinhorst, and D Ross. 2005. "Two Alternative Juvenile Life History Types for Fall Chinook Salmon in the Snake River Basin.” Transactions of the American Fisheries Society 134:291-304.

Endangered Species Act. 16 USC 1531 et seq.

ENSR/AECOM. 2007. Surface Bypass Program Comprehensive Report. Final report prepared by ENSR/AECOM, BioAnalysts, and Pacific Northwest National Laboratory and submitted to the U.S. Army Corps of Engineers, Portland District, Portland, Oregon.

Faber DM, ME Hanks, SA Zimmerman, JR.Skalski, and PW Dillingham. 2005. The Distribution and Flux of Fish in the Forebay of The Dalles Dam in 2003 and Implications for Surface Flow Bypass. PNNL-14628, final report submitted to the U.S. Army Corps of Engineers, Portland District, Portland, Oregon, by Pacific Northwest National Laboratory, Richland, Washington.

Ferguson JW, GM Matthews, RL McComas, RF Absolon, DA Brege, MH Gessel, and LG Gilbreath. 2005. "Passage of Adult and Juvenile Salmonids Through Federal Columbia River Power System Dams.” U.S. Department of Commerce, National Oceanic and Atmospheric Administration, Northwest 
Fisheries Science Center, Seattle, Washington.

Giorgi AE and JR Stevenson. 1995. A Review of Biological Investigations Describing Smolt Passage Behavior at Portland District Corps of Engineer Projects: Implications to Surface Collection Systems. Report submitted to the U.S. Army Corps of Engineers, Portland District, Portland, Oregon, by Don Chapman Consultants, Inc., Boise, Idaho.

Healey MC. 1991. "Life History of Chinook Salmon (Oncorhynchus tshawytscha).” In: C Groot and L Margolis (eds.), Pacific Salmon Life Histories, pp. 312-393, UBC Press, Vancouver, British Columbia.

Johnson GE. 1996. Fisheries Research on Phenomena in the Forebay of Wells Dam in Spring 1995 Related to the Surface Flow Smolt Bypass. Final report submitted to the U.S. Army Corps of Engineers, Walla Walla District, Walla Walla, Washington, by Pacific Northwest National Laboratory, Richland, Washington.

Johnson GE. 2000. Assessment of the Acoustic Screen Model to Estimate Smolt Passage Rates at Dams: Case Study at The Dalles Dam in 1999. Final report by BioAnalysts, Inc. submitted to Waterways Experiment Station, Vicksburg, Mississippi.

Johnson GE, SM Anglea, NS Adams, and TO Wik. 2005. "Evaluation of the Prototype Surface Flow Bypass for Juvenile Salmon and Steelhead at the Powerhouse of Lower Granite Dam, Snake River, Washington, 1996-2000.” N. Amer. J. Fish. Management 25:138-151.

Johnson GE and DD Dauble. 2006. "Surface Flow Outlets to Protect Juvenile Salmonids Passing through Hydropower Dams.” Reviews in Fisheries Science 14:213-244.

Johnson GE, JB Hedgepeth, JR Skalski, and AE Giorgi. 2004. “A Markov Chain Analysis of Fish Movement to Determine Entrainment Zones.” Fisheries Research 69:349-358.

Johnson GE, F Khan, GR Ploskey, JS Hughes, and ES Fisher. 2010. “Optimization of Hydroacoustic Equipment Deployments at Lookout Point and Cougar Dams, Willamette Valley Project, 2010.” PNNL19293, final report submitted to the U.S. Army Corps of Engineers, Portland District, Portland, Oregon, by Pacific Northwest National Laboratory, Richland, Washington.

Johnson GE, GR Ploskey, JB Hedgepeth, F Khan, RP Mueller, MC Richmond, and MA Weiland. 2009a. "Reducing the Impacts of Hydroelectric Dams on Juvenile Anadromous Fishes: Bioengineering Evaluations Using Acoustic Imaging in the Columbia River, USA.” In: Dams, Impacts, Stability and Design, WP Hayes and MC Barnes (eds). Nova Science Pub., Inc., Hauppauge, New York.

Johnson GE, MC Richmond, JB Hedgepeth, GR Ploskey, and eight co-authors. 2009b. Smolt Responses to Hydrodynamic Conditions in Forebay Flow Nets of Surface Flow Outlets, 2007. PNNL-17387, final report submitted to the U.S. Army Corps of Engineers, Portland District, Portland, Oregon, by Pacific Northwest National Laboratory, Richland, Washington.

Johnson GE, CM Sullivan, and MW Erho. 1992. "Hydroacoustic Studies for Developing a Smolt Bypass System at Wells Dam.” Fisheries Research 14:221-237. 
Keefer ML and CC Caudill. 2010. A Review of Adult Salmon and Steelhead Life History and Behavior in the Willamette River Basin: Identification of Knowledge Gaps and Research Needs. Technical Report 2010-8, final report submitted to the U.S. Army Corps of Engineers, Portland District, by the University of Idaho, Moscow, Idaho.

Keefer ML, GA Taylor, DF Garletts, CK Helms, GA Gauthier, TM Pierce, and CC Caudill. 2011. Downstream Fish Passage Above and Below Dams in the Middle Fork Willamette River: A Multi-Year Summary. Joint Technical Report 2011-2 (Draft) prepared by the University of Idaho and the U.S. Army Corps of Engineers, Portland, Oregon.

Khan F, GE Johnson, and MA Weiland. 2009. Hydroacoustic Evaluation of Overwintering Summer Steelhead Fallback and Kelt Passage at The Dalles Dam 2008-2009. PNNL-18590, final report to the U.S. Army Corps of Engineers, Portland District, Portland, Oregon, by Pacific Northwest National Laboratory, Richland, Washington.

Khan F, GE Johnson, and MA Weiland. 2010. Hydroacoustic Evaluation of Overwintering Summer Steelhead Fallback and Kelt Passage at The Dalles Dam, 2009-2010. PNNL-19615, final report to the U.S. Army Corps of Engineers, Portland District, Portland, Oregon, by Pacific Northwest National Laboratory, Richland, Washington.

Koski KV. 2009. "The Fate of Coho Salmon Nomads: the Story of an Estuarine-Rearing Strategy Promoting Resilience.” Ecology and Society 14:4 (online). Available at http://www.ecologyandsociety.org/vol14/iss1/art4/ (March 2011).

Love RH. 1977. "Target Strength of an Individual Fish at Any Aspect.” Journal of the Acoustical Society of America 62:1397-1403.

MacLennan DN and E J Simmonds. 1992. Fisheries Acoustics. Chapman and Hall, London.

Marsh DM, JR Harmon, NN Paasch, KL Thomas, KW McIntyre, WD Muir, and WP Connor. 2009. A Study to Understand the Early Life History of Snake River Fall Chinook Salmon, 2006. Report of research by National Marine Fisheries Service and U. S. Fish and Wildlife Service for the U.S. Army Corps of Engineers, Walla Walla District, Walla Walla, Washington.

Monzyk FR, JD Romer, R Emig, and TA Friesen. 2011a. Life-History Characteristics of Juvenile Spring Chinook Salmon Rearing in Willamette Valley Reservoirs. Draft report submitted by Oregon Department of Fish and Wildlife to the U.S. Army Corps of Engineers, Portland District, Portland, Oregon.

Monzyk FR, JD Romer, R Emig, and TA Friesen. 2011b. Pilot Head-of-Reservoir Juvenile Salmonid Monitoring. Draft report submitted by Oregon Department of Fish and Wildlife to the U.S. Army Corps of Engineers, Portland District, Portland, Oregon.

National Marine Fisheries Service (NMFS). 2008. Willamette River Basin Flood Control Project. Biological Opinion. July 11, 2008, NMFS, Northwest Region, Seattle, Washington.

Ploskey GR and TJ Carlson. 1999. “Comparison of Hydroacoustic and Net Estimates of Fish Guidance Efficiency of an Extended Length Bar Screen at John Day Dam.” N. Am. J. Fish. Manage. 19:1066-1079. 
Ploskey GR, GE Johnson, AE Giorgi, RL Johnson, JR Stevenson, CR Schilt, PN Johnson, and DS Patterson. 2007a. Synthesis of Biological Reports on Juvenile Fish Passage and Survival at Bonneville Dam, 1939-2005. PNNL-15041, final report to the U.S. Army Corps of Engineers, Portland District, Portland, Oregon, by Pacific Northwest National Laboratory, Richland, Washington.

Ploskey GR, CR Schilt, J Kim, CW Escher, and JR Skalski. 2003. Hydroacoustic Evaluation of Fish Passage Through Bonneville Dam in 2002. PNNL-14356, final report to the U.S. Army Corps of Engineers, Portland District, Portland, Oregon, by Pacific Northwest National Laboratory, Richland, Washington.

Ploskey GR and MA Weiland. 2006. Hydroacoustic Evaluation of Fish Passage through Trail Bridge Dam (2004-2005). PNWD-3596, prepared for Stillwater Sciences and the Eugene Water Electric Board, Eugene, Oregon, by Battelle-Pacific Northwest Division, Richland, Washington.

Ploskey GR, MA Weiland, and J Kim. 2007b. “Evaluating Tradeoffs for Efficiently Passing Juvenile Salmonids through Bonneville Dam on the Lower Columbia River.” Fourth International Reservoir Fisheries Symposium, in Atlanta, Georgia, Amercian Fisheries Society, Bethesda, Maryland.

Ploskey GR, MA Weiland, CR Schilt, J Kim, PN Johnson, ME Hanks, DS Patterson, JR Skalski, and JB Hedgepeth. 2005. Hydroacoustic Evaluation of Fish Passage Through Bonneville Dam in 2004. PNNL15249, final report to the U.S. Army Corps of Engineers, Portland District, Portland, Oregon, Pacific Northwest National Laboratory, Richland, Washington.

Quinn TP. 2005. The Behavior and Ecology of Pacific Salmon and Trout. University of Washington Press, Seattle, Washington.

Smith DL, JM Nestler, GE Johnson, and RA Goodwin. 2009. "Species-Specific Spatial and Temporal Distribution Patterns of Emigrating Juvenile Salmonids in the Pacific Northwest.” Reviews in Fisheries Science 18:40-64.

Sokal RR and FJ Rohlf. 1981. Biometry. W.H. Freeman and Company, San Francisco, California.

Thorne RE and GE Johnson. 1993. "A Review of Hydroacoustic Studies for Estimation of Salmonid Downriver Migration Past Hydroelectric Facilities on the Columbia and Snake Rivers in the 1980s.” Reviews in Fisheries Science 1:27-56.

U.S. Army Corps of Engineers (USACE). 2009. Comprehensive Plan For Research, Monitoring, and Evaluation in the Willamette River Basin. Draft, U.S. Army Corps of Engineers, Portland District. Portland, Oregon.

Waples RS, T Beechie, and GR Pess. 2009. "Evolutionary History, Habitat Disturbance Regimes, and Anthropogenic Changes: What Do These Mean for Resilience of Pacific Salmon Populations? Ecology and Society 14(1):3 (online). Available at http://www.ecologyandsociety.org/vol14/iss1/art3/.

Williams RN (ed). 2006. Return to the River: Restoring Salmon Back to the Columbia River. Elsevier Academic Press, Burlington, Maine. 
Appendix A

Hydroacoustic System Parameters 



\section{Appendix A - Hydroacoustic System Parameters}

Legend for Table A.1 (next page)
A. System
B. Echo-sounder number
C. Channel
D. Transducer number and phase (if split beam)
E. Calibrated cable length ( $\mathrm{ft}$ )
F. Source level (dB)
G. $-6 \mathrm{~dB}$
H. Maximum output voltage $(\mathrm{dB})$
I. $\mathrm{G} 140 \log$ receiver sensitivity $(\mathrm{dB})$
J. Target strength of largest on-axis target of interest $(\mathrm{dB})$
K. Calculated receiver gain $(\mathrm{dB})$
L. Installed cable length (ft)
M. Difference in cable length between calibrated cable and installed cable (ft)
N. Receiver gain adjusted for difference in cable length $(\mathrm{dB})$
O. Source level adjusted for difference in cable length $(\mathrm{dB})$
P. Receiver sensitivity adjusted for difference in cable length $(d B)$
Q. Target strength of smallest on-axis target $(\mathrm{dB})$
R. Voltage of smallest on-axis target (dB); voltage of smallest on-axis target at $20 \mathrm{~dB}$ per volt (V) 
Table A.1. Hydroacoustic System Parameters Used at LOP, 2010

\begin{tabular}{|c|c|c|c|c|c|c|c|c|c|c|c|c|c|c|c|c|c|}
\hline A & B & C & D & $\mathbf{E}$ & $\mathbf{F}$ & G & H & I & $\mathbf{J}$ & $\mathbf{K}$ & L & M & $\mathbf{N}$ & 0 & $\mathbf{P}$ & $\mathbf{Q}$ & $\mathbf{R}$ \\
\hline H & 8 & 0 & 29 & 485 & & 80 & & -26 & 5.23 & & 0 & & & 13.39 & -56 & 50 & \\
\hline H & 8 & 1 & 28 & 485 & 214.16 & 80 & -11339 & -26 & 5.23 & 486 & -1 & 5.24 & 214.16 & -113.40 & -55 & 51 & 2.55 \\
\hline $\mathbf{Q}$ & 23 & & $443(\mathrm{x})$ & 705 & 213.50 & 80 & 11050 & -26 & 3.00 & 705 & 0 & & 213.50 & -110.50 & -56 & 50 & 2.50 \\
\hline $\mathbf{Q}$ & 23 & & $443(y)$ & 705 & 213.46 & 80 & -110.50 & -26 & 3.04 & 705 & 0 & 3.04 & 213.46 & -110.50 & -56 & 50 & 2.50 \\
\hline $\mathbf{Q}$ & 23 & 0 & & 705 & 13.48 & 80 & 10.50 & -26 & 3.02 & 705 & 0 & 3.02 & 213.48 & -110.50 & -56 & 50 & 2.50 \\
\hline $\mathbf{Q}$ & 23 & & $444(x)$ & 705 & 213.04 & 80 & -111.30 & -26 & 4.26 & 705 & 0 & 4.26 & 213.04 & -111.30 & -56 & 50 & 2.50 \\
\hline $\mathbf{Q}$ & 23 & & $444(y)$ & 705 & 213.16 & 80 & 1112 & -26 & 4.08 & 705 & 0 & & 213.16 & -111.24 & -56 & 50 & 2.50 \\
\hline $\mathbf{Q}$ & 23 & 1 & & 705 & 213.10 & 80 & -111.27 & -26 & 4.17 & 705 & 0 & 4.17 & 213.10 & -111.27 & -56 & 50 & 2.50 \\
\hline $\mathbf{Q}$ & 23 & & 445 (x) & 705 & 213.06 & 80 & -111.54 & -26 & 4.48 & 940 & -235 & 6.58 & 212.16 & -112.74 & -56 & 50 & 2.50 \\
\hline $\mathbf{Q}$ & 23 & & $445(\mathrm{y})$ & 705 & 213.22 & 80 & -111.36 & -26 & 4.14 & 940 & -235 & 6.24 & 212.32 & -112.56 & -56 & 50 & 2.50 \\
\hline $\mathbf{Q}$ & 23 & 2 & & 705 & 213.14 & 80 & -111.45 & -26 & 4.31 & 940 & -235 & 6.41 & & -112.65 & -56 & 50 & 2.50 \\
\hline $\mathbf{Q}$ & 23 & & $446(x)$ & 704 & 212.90 & 80 & -111.50 & -26 & 4.60 & 940 & -236 & 6.71 & 211.99 & -112.70 & -56 & 50 & 2.50 \\
\hline $\mathbf{Q}$ & 23 & & $446(y)$ & 704 & 212.89 & 80 & -111.62 & -26 & 4.73 & 940 & -236 & 6.84 & 211.98 & -112.82 & -56 & 50 & 2.50 \\
\hline $\mathbf{Q}$ & 23 & 3 & 446 & 704 & 212.90 & 80 & -111.56 & -26 & 4.66 & 940 & -236 & 6.77 & 211.99 & -112.76 & -56 & 50 & 2.50 \\
\hline $\mathbf{U}$ & 21 & & & 705 & 13.10 & 80 & & -26 & 6.06 & 705 & 4 & & & & -56 & 50 & 2.50 \\
\hline $\mathbf{U}$ & 21 & & $405(y)$ & 705 & 213.17 & 80 & -113.12 & -26 & 5.95 & 705 & 0 & 5.95 & 213.17 & -113.12 & -56 & 50 & 2.50 \\
\hline $\mathbf{U}$ & 21 & 0 & 405 & 705 & 213.14 & 80 & -113.14 & -26 & 6.00 & 705 & 0 & 6.00 & 213.14 & -113.14 & -56 & 50 & 2.50 \\
\hline $\mathbf{U}$ & 21 & & $406(x)$ & 698 & 213.05 & 80 & -111.76 & -26 & 4.71 & 698 & 0 & 4.71 & 213.05 & -111.76 & -56 & 50 & 2.50 \\
\hline $\mathbf{U}$ & 21 & & $406(y)$ & 698 & 214.21 & 80 & -111.74 & -26 & 3.53 & 698 & 0 & 3.53 & 214.21 & -111.74 & -56 & 50 & 2.50 \\
\hline $\mathbf{U}$ & 21 & 1 & 406 & 698 & 213.63 & 80 & -111.75 & -26 & 4.12 & 698 & 0 & 4.12 & 213.63 & -111.75 & -56 & 50 & 2.50 \\
\hline $\mathbf{U}$ & 21 & & 40 & 705 & 213.14 & 80 & -111.18 & -26 & 4.04 & 705 & 0 & 4.04 & 213.14 & -111.18 & -56 & 50 & 2.50 \\
\hline $\mathbf{U}$ & 21 & & $407(y)$ & 705 & 213.33 & 80 & -111.10 & -26 & 3.77 & 705 & 0 & 3.77 & 213.33 & & -56 & 50 & 2.50 \\
\hline $\mathbf{U}$ & 21 & 2 & & 705 & 213.24 & 80 & -111.14 & -26 & 3.90 & 705 & 0 & 3.90 & 213.24 & -111.14 & -56 & 50 & 2.50 \\
\hline
\end{tabular}




\section{Distribution}

No. of

Copies (PDF)

OFFSITE

7 David Griffith

U.S. Army Corps of Engineers

P.O. Box 2946

Portland, OR 97208
No. of

Copies (PDF)

\section{ONSITE}

7 Pacific Northwest National Laboratory

F Khan

K6-85

GE Johnson

DM Trott

IM Royer

GR Ploskey

JS Hughes

ES Fischer
BPO

K6-85

NBON

NBON

NBON

NBON 




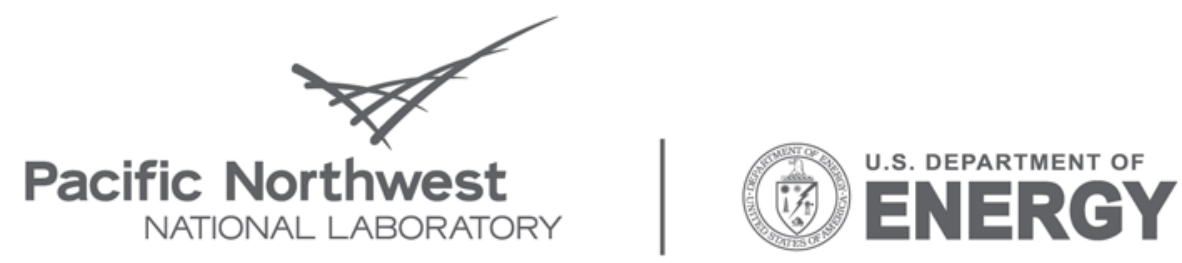

Proudly Operated by Battelle Since 1965

902 Battelle Boulevard

P.O. Box 999

Richland, WA 99352

1-888-375-PNNL (7665)

www.pnl.gov 